الأبعاد المعرفية والبنائية للصورة الكتابية في الفن المفاهيسي

م.د. فاطمة عبد الله عمران

هلفص البحث

يتلخص البحث الحالي بدر اسة (الابعاد المعرفية و البنائيـة للصورة الكتابية في الفن المفاهيمي) إذ تضمن البحث أربعة فصول

تضمن الفصل الأول مشكلة البحث إذ أن البحث في هذا المجال هو حصيلة التراكب المعرفي وانظمة الفكر السائدة ومن هنا استوقف الباحثة التساؤل الآتي : هل تتفرد الصورة الكتابية في الفن المفاهيمي بأبعاد معرفية وبنائية خاصة وبأبي كيفية تم ذلك؟ فيمـا تكمن أهمية البحث في في لهي القاء الضوء على اثتغالات الافكار الفلسفية والمعرفية التي اسست لفنون ما بعد الحداثة ومن هذه الاتجاهات (اللاعقلانية و التفكيكية ، و البنيوية و العدمية) وتأثير ها في البعد البنائي للصورة الكتابية في الفن المفاهيمي ، أما أهداف البحث فيهدف البحث الحالي إلى تعرف البعد المعرفي للصورة الكتابية في الفن المفاهيمي، وتعرف البعد البنائي للصورة الكتابيـة في الفن المفاهيمي. وتم تحديد حدود البحث موضو عياً بدر اسـة

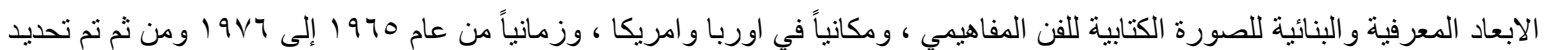
المصطلحات والتعريف الاجر ائي ـ أما الفصل الثاني فتضمن الإطار النظري وضم مبحثين : الأول الابعاد المعرفية للصورة الكتابية في الفن المفاهيمي من خلال: التحو لات المعرفية في فكر مـا بعد الحداثة و التحو لات المعرفية في الفن المفاهيمي. و المبحث الثاني: الابعاد البنائية للصورة الكتابية في الفن المفاهيمي ، وانتهى الفصل الثاني بأهم المؤشرات التي اسفر عنها الإطـار النظري ، أمـا الفصل الثالث فتضمن إجر اءات البحث. وقد تكون مجتمع البحث من الاعمال الفنية لفن ما بعد الحداثة (الفن المفاهيمي) وبالتحديد ما يخص فن اللغة وقد بلغ عدد بهد مجتمع البحث (ب0) عمل فني وتم اختيار عينـة البحث بطريقة قصدية وكان عددها (0) عينة، واعتمدت الباحثة في بنـاء استمارة التحليل لبحثها على مؤشر ات الإطار النظري المتكونة من محورين المعرفي والبنائي، واستخدمت الباحثة معادلة كوبر لاستخر اج صدق الاداة الذي

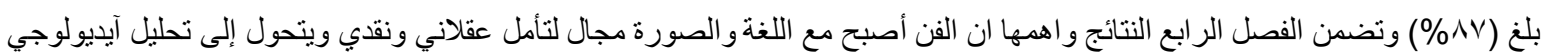
على وفق لغته المكتوبة ليتحول العمل الفني إلى فن ثقافي فلسفي ولغوي لذا ابتعد الجانب المعرفي و البنائي للعمل عن وظيفة الثكل لأن الفن انتقل من الثكل إلى اللغة كما في جميع نماذج عينة البحث. ومع الفن المفاهيمي فان العمل الفني عملية ذهنية إذ ينطلق الفنان من اشياء حقيقية وداخل فضاء حقيقي ليمضي بمفهومه إلى ابعد مما تعنيه الصورة واللغة الكتابية المقروءة والثيء المصور يعكس صورة الفكر نفسهـ لذا لا لاهي

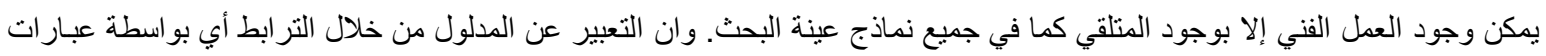

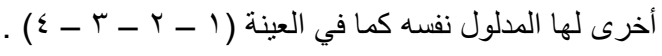

\title{
Abstract:
}

The current research is briefed by studying ( COGNITIVE AND STRUCTURAL LIMITS FOR THE SCRIPT PICTURE IN THE CONCEPTUAL ART), the research includes four chapters, first chapter concerned about the problem of research that as researching in this field is the result of the cognitive combination and the common intellectual systems so the researcher was stopped by the following inquiry : Does the script picture have it's special cognitive and structural limits and how so?

The importance of the research is represented by shedding light on working on cognitive and philosophical thoughts that based for post-modernity arts such as orientations are ( insanity, deconstruction, humanism and non-existence ) and its effect on the structural limit of the script picture in the conceptual art, the goals of the research are:

1- Knowing the cognitive limit of the script picture in the conceptual art.

2- Knowing the structural limit of the conceptual picture in the conceptual art.

Limits of the research was specified topically by studying the cognitive and structural limit of the script picture for the conceptual art, by place through Europe and America, by time from 1965 to 1970, then specified terms and procedural definition.

Second chapter included the theoretical frame and included two sections: first one is the cognitive limit of the structural picture in the conceptual art through: 
1- $\quad$ Cognitive modifications of the post-modernity art .

2- Cognitive modifications in the conceptual art.

Second section was about the structural limits of the script picture in the conceptual art, second chapter was ended with most important indications that rose from the theoretical frame, while Third chapter included procedures of the research.

The community of the research consists from artistic works of the post-modernity art (conceptual art) and what pertains the language art particularly, total works of population are (25) artistic work and choosing the research's sample intentionally were (5) samples, the researcher relied on indications of the theoretical frame which consisted from two pivots cognitive and structural during creating the analyzing form, she used Coper equation to determine the credibility of the tool which was $(87 \%)$, fourth chapter included the conclusions , most important ones are:

1- $\quad$ The art with language and picture become a space for a reasonable and criticizing meditation and moved to ideological analyzing according to its written language then the artistic work will move to a cultural philosophical and linguistic therefor the cognitive and structural side get far away from the job of the shape because the art transferred from the shape to the language as shown in all samples of the research.

2- With the conceptual art so the artistic work is an intellectual process that the artist starts from a real things inside a real space to go with his concept to farther than what the picture means, the readable script language and the depicted thing reflects the image of the intellect itself, so there is no existence for the artistic work without viewer as we have seen in all samples of the research.

3- $\quad$ Expression of the guide through the correlation i.e. (using another phrases have the same guide as in the sample no. $(1,2,3,4)$.

\section{The conclusions:}

- $\quad$ Clearness of the active role of the criticizing curriculums (structure, deconstruction, Simyaia) in changing the classic styles of the structure of modern painting and to replace it with structural and cognitive depending on conceptual and intellectual side to confirm on the image of the intellect itself.

Then specifying the most recommendations that researcher confirmed on, then his suggestions.

\section{الفصل الأول- هشكلة البحث وأهمية والحاجة إليه}

شهد الفن على مر التاريخ أزمات فنية كبيرة أدت إلى تحولات هامة في البنى و العلاقات الاجتماعيـة،

وكونت مفردات تشكيلية جديدة، فالفن الذي يـرتبط ارتباطاً وثيقاً ومباثـراً بمختلف القوى الفاعلة في تـاريخ تطور المجتمع، ماديـاً وفكريـاً، لا ينفصـل عن مجموعـة العلاقـات الاجتماعيـة ، ومن هنـا نتظر إلى التحو لات الفنية الكبرى التي شهدها العالم الغربي مع نهاية القرن التاسع عشـر وبدايات القرن العثرين ، تلك التحو لات المتمثلة في تيار ات فنية كانت تسعى، في مجتمع تكونـت لايـه مقومـات فكريـة وتقنية جديدة، للتحرر من نمط فني رسمت اطره العامة وحددت ابعاده منذ عصر النهضة و التي وضعت نظاماً فنياً على رؤيسة عقلانبـة للعـالم و الإنسان، التي ارتبطت بتبدل عميق للمعارف التقتية والنظرية وللعلاقات الاجتماعية(').

فالفن الحديث بدأ مع الانطباعية، وان لم تتوضح منطلقاتـه الأساسية إلا في بدايـة القرن العثرين، بـل

في السنوات العثر التي سببت الحرب العالمبة الأولى، بيد ان جذور هذا الفن تبقى مرتبطة بمـا شهده العالم الغربي بعد الثورة الفرنسية من تبدل في مفـاهيم انعكست آثار هـا على تصـور الحركة الفنيـة في القرن التاسـع عشر. لذلك لم يعد التصور يقتصر على تمثيل العالم المرئي لكنه بات تجسيداً عفويـاً للمعانـاة أو تجسيد للحركة أو الفعل و اللون فلم يعد بالضـرورة المطابقة لمظاهر الأشياء كمـا تر اهـا العين، فمع فان كوخ اكتسب اللوحة 
الحداثوية قيماً ذاتية تسهح لامر نقل الطبيعة كما هي، بل في اعادة بنائها وخلقها من جديد ، بل هي تحسين لقيم

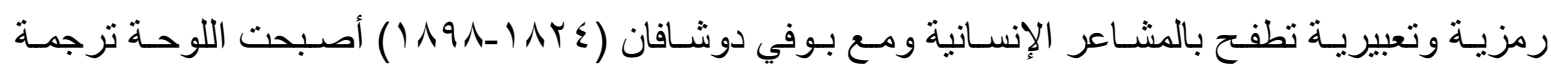
تتكيلية للفكرة السامية و المثالية. ومع الفن التجريدي حلت الفكرة محل الصورة في مجال التعبير الفني كنتيجة لتحرر الفنان إزاء الموضوع أي ان الفن بات يتعامل مع الفكرة والثعور أو الحس ، أو مـا يسميه كاندا نسكي "الضرورة الداخلية" وفي مجادلة "لجعل اللامرئي مرئياً" بحسب تعبير بول كلي. وبذلك فالتحو لات التي ادخلها تقدم التقنيات في الوسط الإنسـي، ومـا ر افقها من تبدل في الاعر اف والأفكار نتيجـة التطور العلمي، والفلسفات الجديدة هي التي مهدت لهذا التطور الكبير على صعيد الفنون التتكيلية ـ لكن الفن الغربي المتأرجح بين العالم الموضوعي و العالم الداخلي الذاتي لن ينوقف عند مسألة

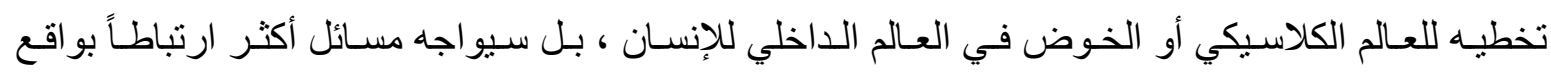

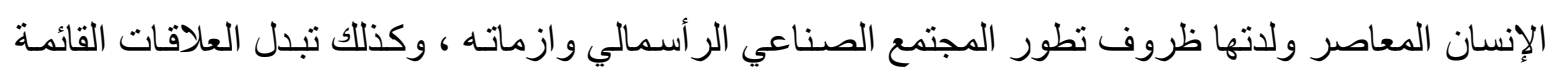

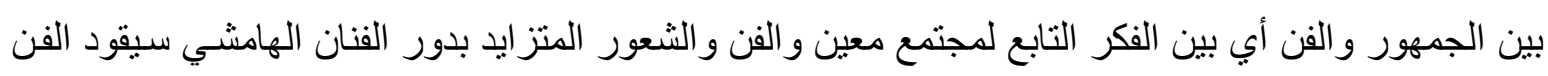
إلى حدود العبثية ونفي الفن مع الدادائية (في نهاية الحرب العالمية الأولى) فهي تهاجم سلطة الفن وتطالب مـع

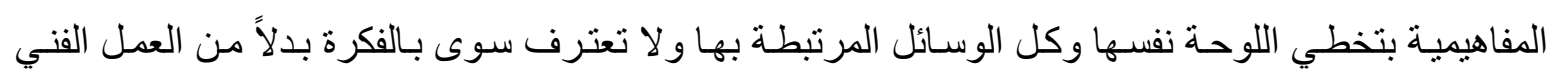

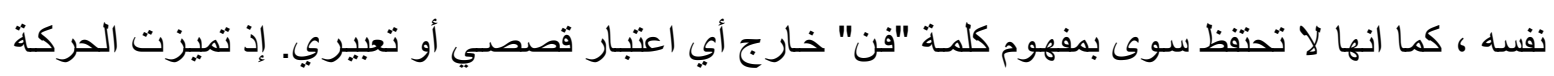

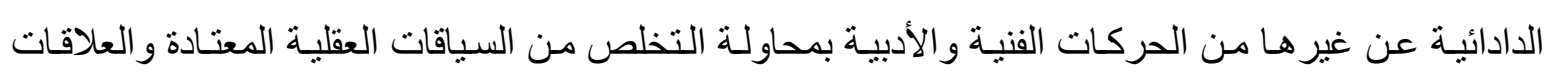
السببية في التفكير والتعبير والتخلص من كل مـا يعوق الحركة ويكبح جموح التلقائية في التعبير والإبداع

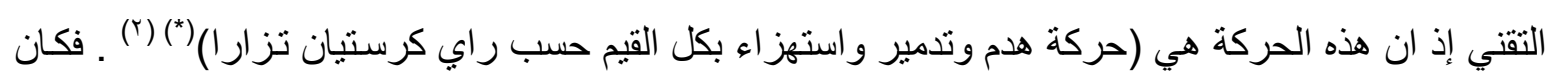

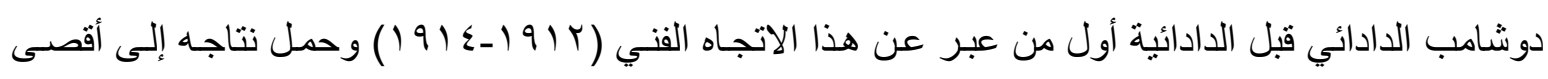

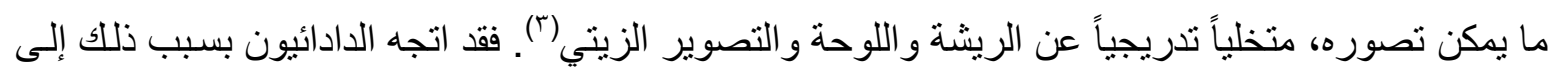
العبث ، و ادت هذه الأفكار بالدادائيين إلى البحث عن مغزى جديد للجمال وقيمه في كل مجالات الحياة ومنها الفن(₹)

وبذللك تعد ظـاهرة مـا بعد الحداثـة نتـاج تحول تـاريخي شـامل نحو شكل جديـ من اثـكال التقافة المعاصرة ، التي داهمت المجتمعات الغربية منذ منتصف القرن العشرين وكرد فعل على كل هذه التحو لات نشأت حركات اجتماعية تنادي بنهاية الآيديولوجيات و المعتقدات وتطالب بـالخروج عن كل قياس معياري.

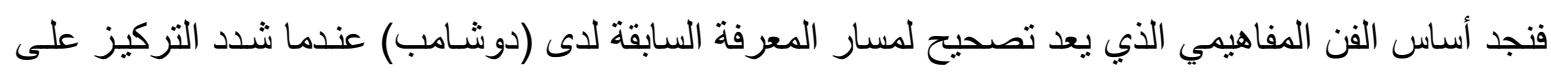
الفكرة إلى جانب العمل ـ وكذللك رينيـه ماغريت الذي طرح مفهومـه الفكري مؤكداً ان فكرة الفن لغـة فهو يصور غليون ويكتب أسفل الصورة هذا ليس غليوناً . تللك المحاو لات المفاهيمية أسفرت عن توسع نطاق الفن ليصبح أكثر من مجرد كونـه نقاش عن علاقة اللون و الشكل باعمال ميزتها الرئيسية هي الفكرة ــ المفهوم

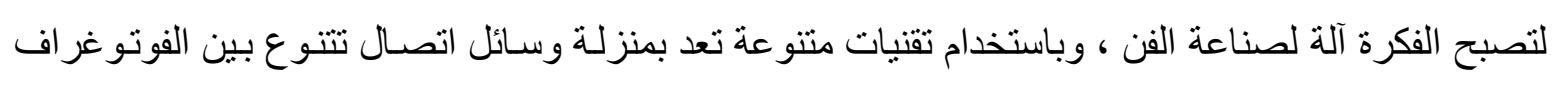
و النصوص و الخر ائط والرسوم البيانية والاشرطة الصوتية وبذلك تخلف الفن المفاهيمي عن التجربـة الجمالية باكملها ليتحول (الجمال الفني) إلى جمال الفكرة وهي الهدف الفعلي. وبذلك فان البحث في الابعاد المعرفية 
و البنائيسة للصـورة الكتابيـة في الفن المفـاهيمي يعد حصيلة التر اكم المعرفي وانظمـة الفكر السـائدة ، من هنـا استوقف الباحثة السؤال التالي: هل تنفرد الصورة الكتابية في الفن المفاهيمي بابعاد معرفية وينائية خاصـة وبأي كيفية تم ذلك؟

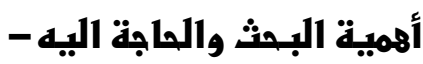

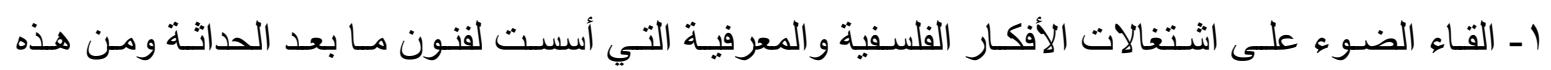
الاتجاهـات (اللاعقلانيـة و التفكيكيـة و البنيويـة و العدميـة) وتأثير هـا في البعـد البنائي للصـورة الكتابيـة في الفـن المفاهيمي.

r- يؤسس البحث الحسالي بدر اسـة معرفية وبنائية تعنى بتسليط الضـوء على اثر الافكار المعرفيـة والفلسفية لفنون ما بعد الحداثة على بنائية العمل الفني وبالذات الصورة الكتابية. أما الحاجة إلبه فنتكمن: ا - يفيد المؤسسات التربوية والعلمية والفنية والدارسين والمتذوقين على السواء. r- رفد المكتبة الوطنية بجهد علمي يزيد من اثراءها بما يخص فنون ما بعد الحداثة .

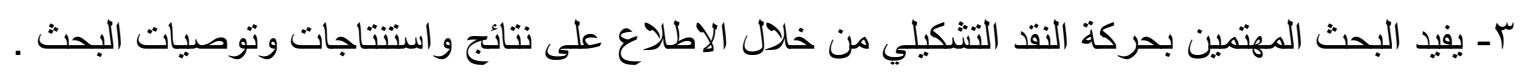

هدفا البهثث ا ـ تعرف البعد المعرفي للصورة الكتابية في الفن المفاهيمي . r- تعرف البعد البنائي للصورة الكتابية في الفن المفاهيمي .

هدود البهث

الدود الموضوعية : يتحدد البحث بدراسة "الابعاد المعرفية والبنائية للصورة الكتابية في الفن المفاهيمي". الحدود المكانية : أوربا وأمريكا

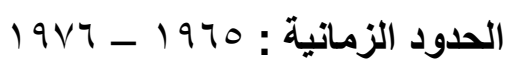
تصديد المصطلحات 1 الأبعاد

أ. لغفً: وردت كلمة (بُعْد) في مختار الصحاح بمعنى (خـلاف القرب) ، أي ضدَّ القُربْ ، وقد (بعَدُ) بالضم

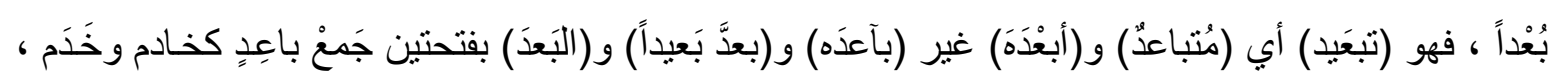

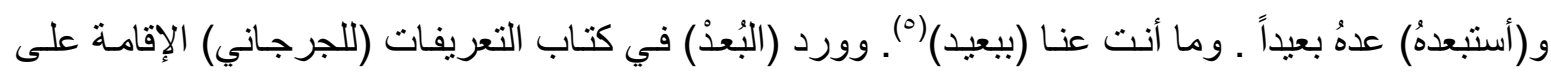

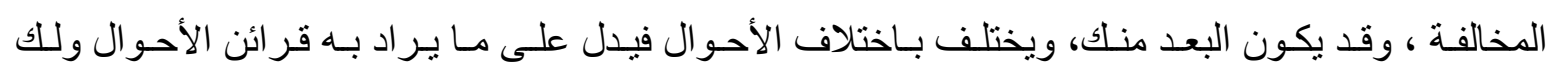

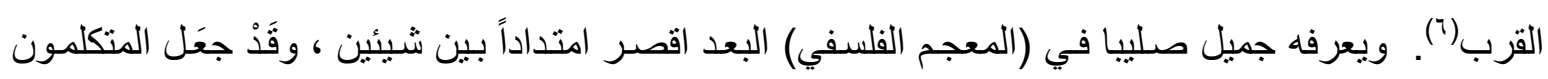

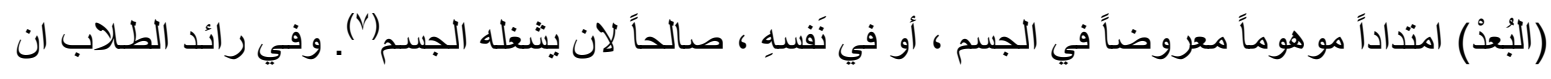

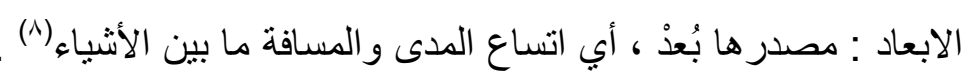


ب. اصطلاحاً: هو في (العلوم الطبيعية): العلاقة التي يتحدد بها المقدار بالنسبة إلى المقادير الأساسية ، وهي

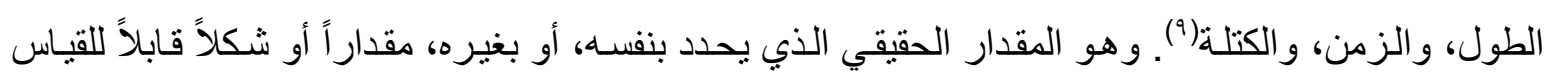

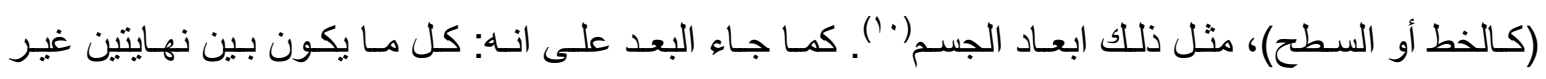
متلاقيتين، و الفرق بين البعد وبين المقادير الثناثة انه قد يكون بعداً خطياً من غير خطوبعداً سطحياً من غير

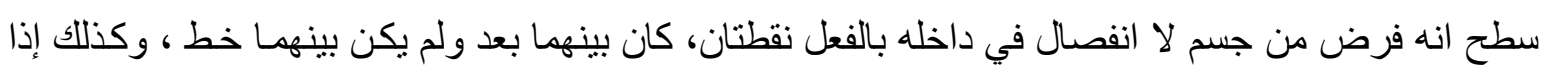

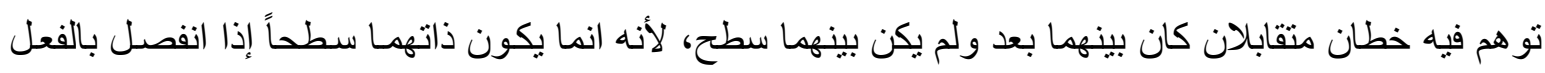

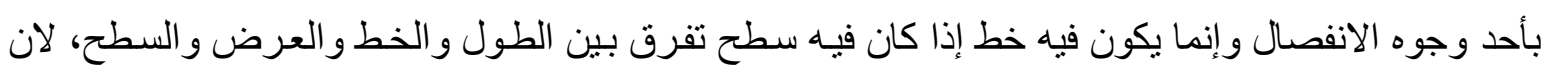

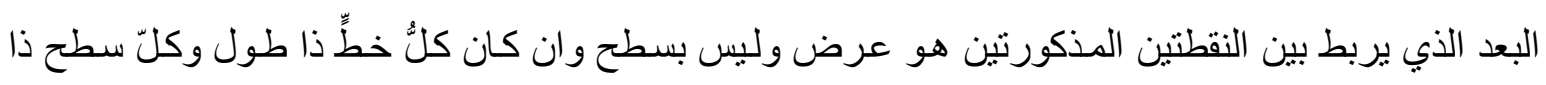
عرض("'). ومن معاني هذا المصطلح، هو المعنى المصطلح عليه من نظريـة المعرفة، وهو ان المعرفة إذا

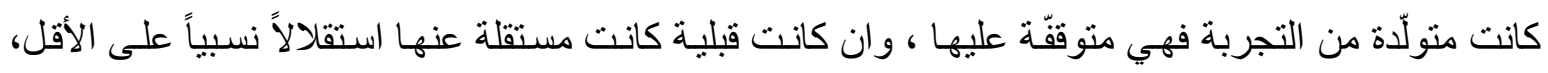
وليس المقصود بـ(قبلية) المعرفة تقدمها على التجربة بالزمان ، بل المقصود بها تقدمها عليها بالذات(r').

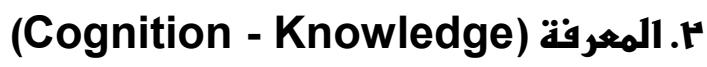

أ. في القرآن الكريم: ما جاء في تفسير الآية: قال تعالى: (وما عرفوا الله حق معرفته)('ا').

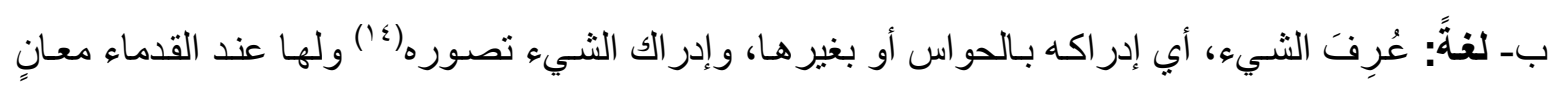

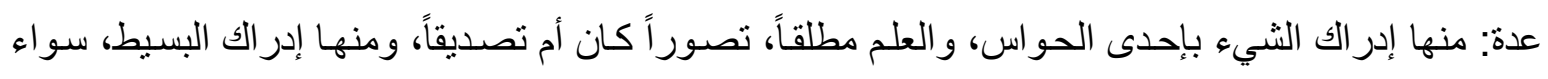

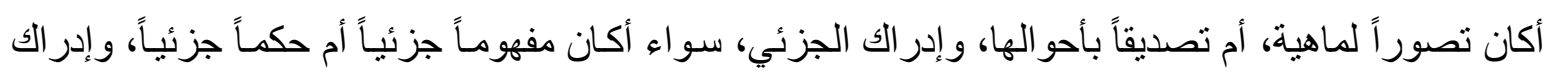

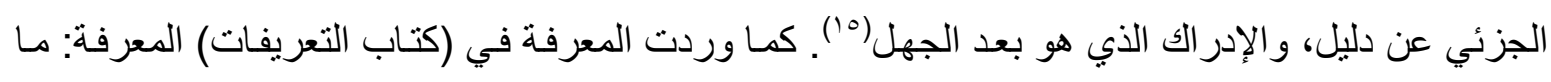

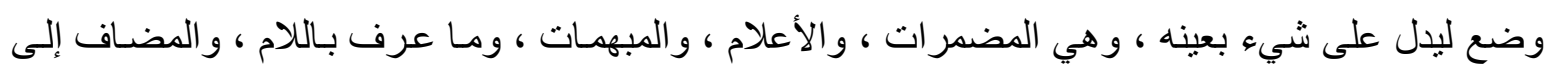

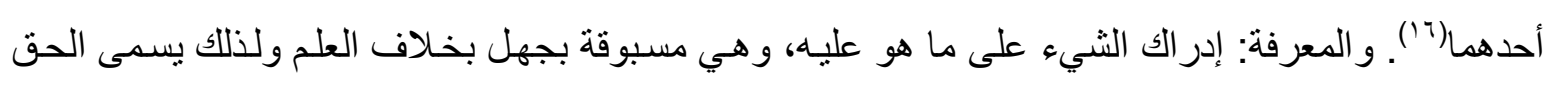

$$
\text { تعالى: بالعالم دون العارف('v'). }
$$

ج. اصطلاحاً: يطلق لفظ المعرفة عند المحدثين على أربع معانٍ: الأول: هو الفعل العقلي الذي يتم بـه حصول

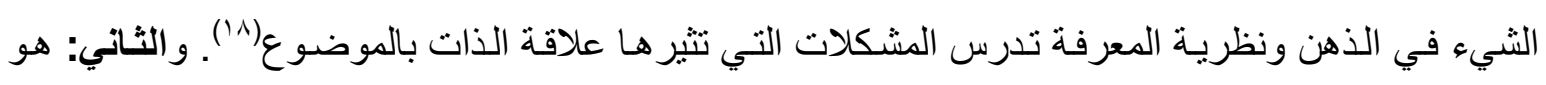
الفعل العقلي الذي يتم به النفوذ إلى جوهر الموضوع لتفهم حقيقته ، بحيث تكون المعرفة الكاملة بالثـيء خالية ذاتيـاً من كل غموض و التبـاس، أو محيطة موضـوعياً بكل مـا هو موجود للثـيء في الو اقع. و الثالث: هو مضمون المعرفة بـالمعنى الأول. والرابع: هو مضمون المعرفة بـالمعنى الثاني. وهذه المعاني وحدها كافية

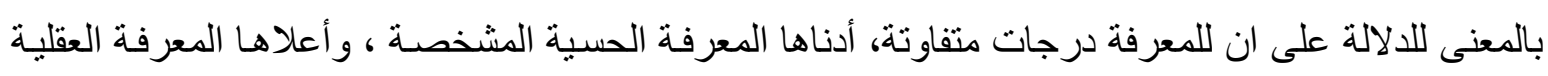
المجردة(19).

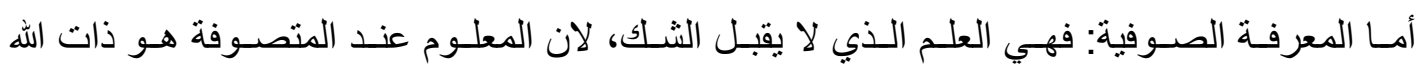

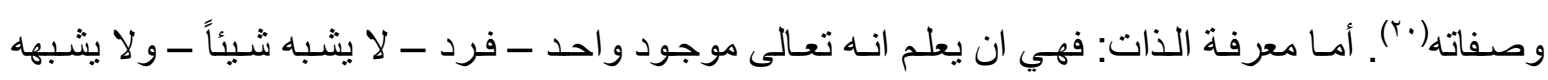

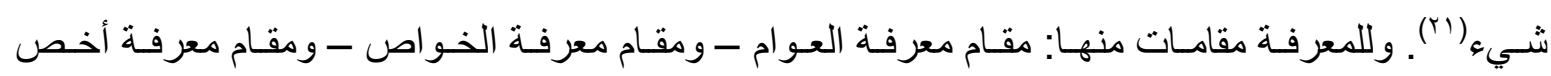

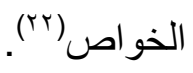


و المعرفة عند (فيثاغورس) تمثلت (بالحدس) في الوصول إلى الحقيقة و إدر الك الواقع من خـلال نظسام

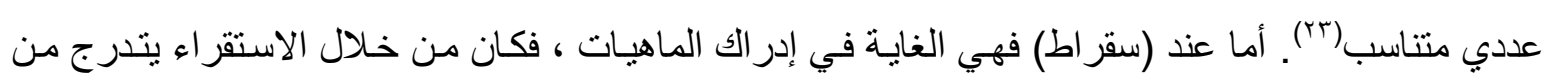
الجزئيات إلى الكليات ، و اكتشف ان المعرفة الحقيقية لبست في ظواهر الأشياء المتغيرة التي تصور ها لنـا

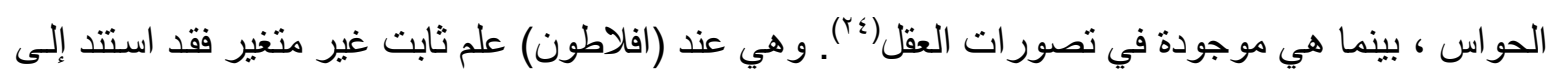

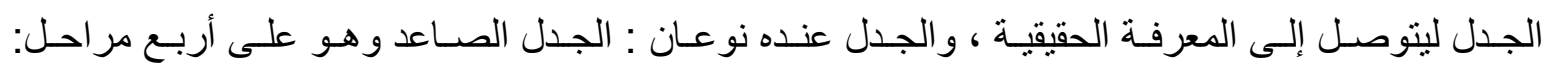

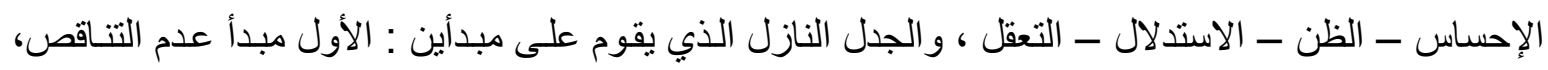
و الثاني مبدأ العلية(ro). و المعرفة عند (أرسطو) هو ان ندرك الثيء قبل إدر اك ماهيته ، وهو يؤكد على ثنلاث

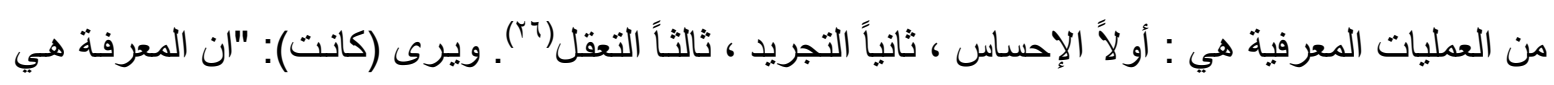
حصيلة مشاركة بين التصور ات الذهنية والحس"(YV) . ويتفق الباحث مع تعريف (كانت) للمعرفة.

$$
\text { وتعرف الباحثة اجر ائياً: }
$$

الابعاد المعرفي: هي عملية التعاطي مع الصورة الفنية من فبل الفنان أو المتلقي من حيث الادر الك الحسي أو العقلي أو المتخيل الذي يتضمن التداخل الكتابي في العمل الفني. الابعاد البنائية: هي عملية تشير إلى آليات اشتغال العناصر الفنية ووسـائل التنظيم الجمالي في التكوين الفني للصورة الكتابية في الفن المفاهيمي.

\section{الفمل الثاني- الإطار النظري}

المبــذ الأورل

ـ الابعاد المعرفية للصورة الكتابية في الفن المفاهيمي ـ التحو لات المعرفية في فكر ما بعد الحداثة . ـ التحو لات المعرفية في الفن المفاهيمي . المبـحث النظانبي ـ الابعاد البنائية للصورة الكتابية في الفن المفاهيمي

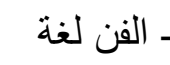

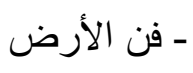

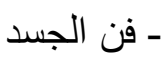

\section{المبـهث الأول - الأبعاد المعرفية للمورة الكنتابية للفزن المفاهي-مي} ا ـ التحولات المعرفية في فكر ما بعد الحداثة

غالباً ما يحاول النقاد و المنظرون قراءة الفكر ما بعد الحداثة، بوصفه انعكاساً لما يحصل من تحو لات

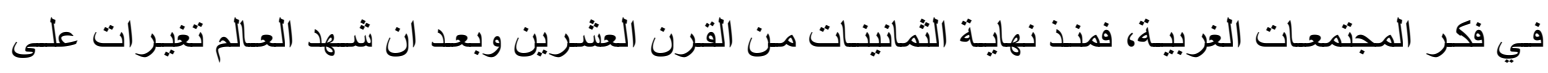
مستوى الفكر والو اقع، انتهى على اثر نظام عالمي فكري وسياسي وكان من أهم تلك الأسباب كمـا شير إليها الجابري متمثلة بسقوط جدار برلين و انهيار الاتحاد السوفيتي ، وتفكك وتلاشي المنظومة الفكريـة الاشتر اكية ، 


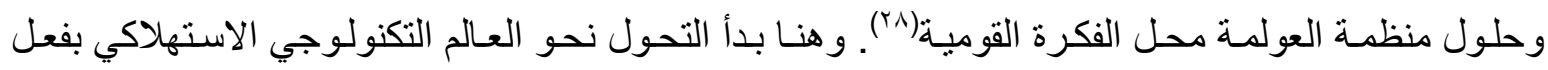

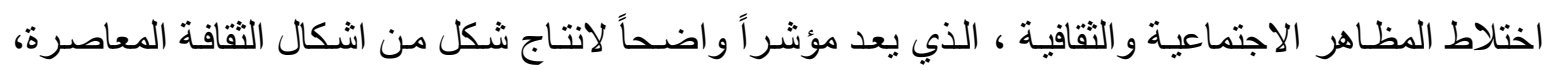

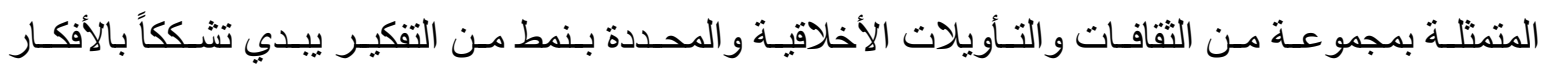

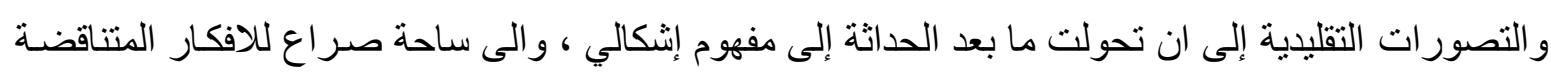
وموضو عاً مثتركاً كتيارات فكرية متنو عة.

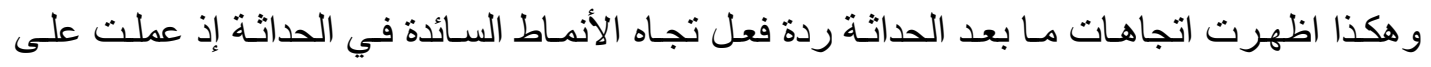

تقويضها وتدمير ها ، وألقت الفو اصل الرئيسية فيها وأهـها تآكل الفاصل القديم بين الثقافة العليا وبين ما بسمى

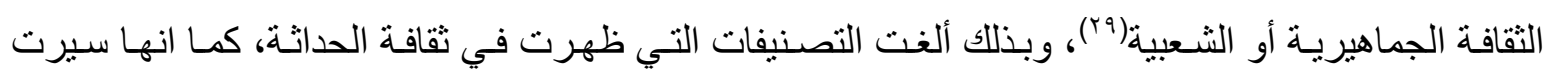

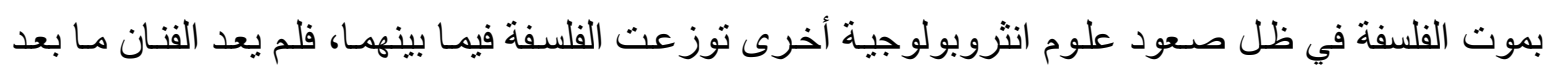

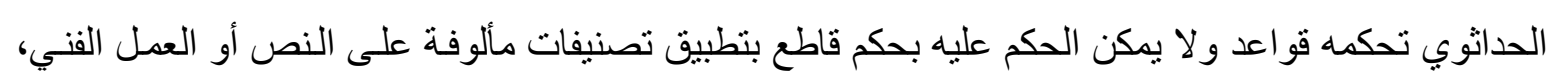

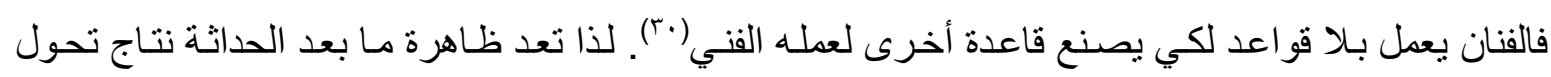

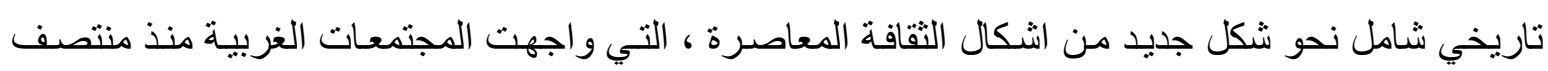

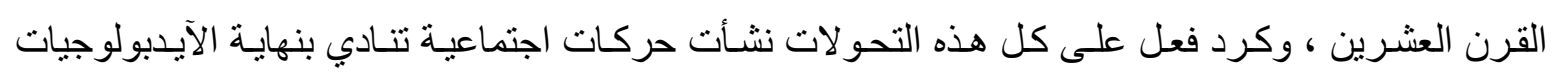

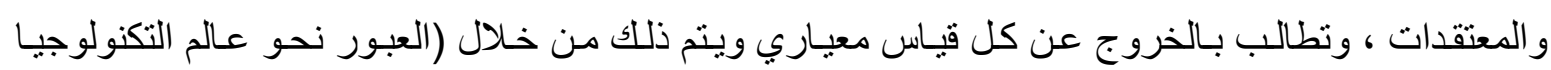

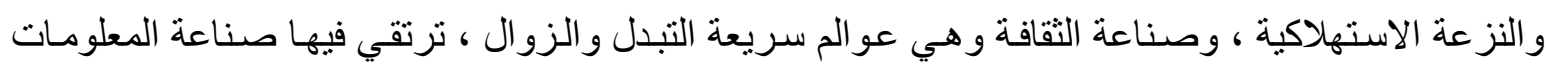

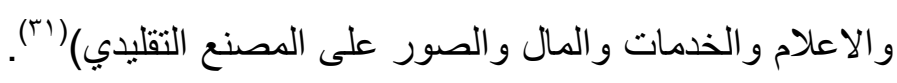

ولان ثقافة ما بعد الحداثة بتوصيف (هارفي) هي مصدر السلطة ، فان ما بعد الحداثة أصبحت تبحث

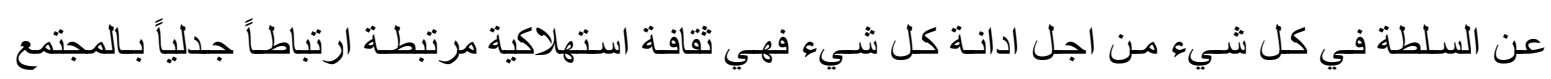

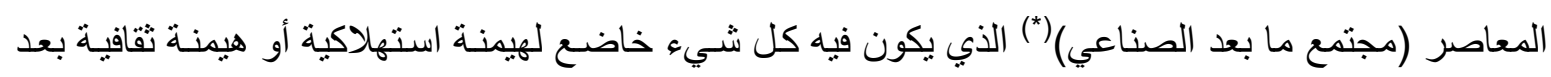

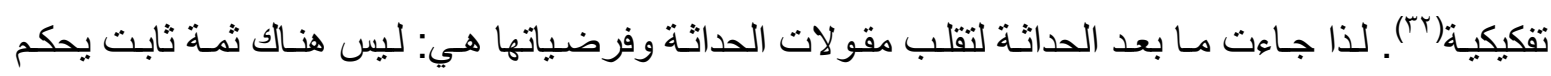

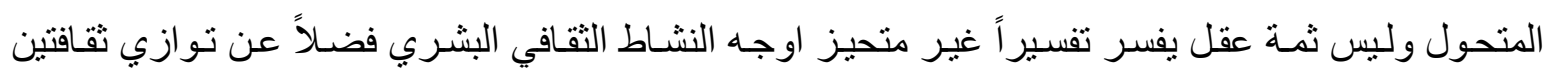

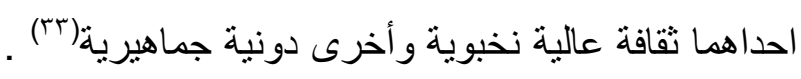

وقد سبق لـــباثشلار) ان اوضـح بـأن معرفـة الو اقع في العـالم ليست معرفة مباثـرة ومكتملـة لان

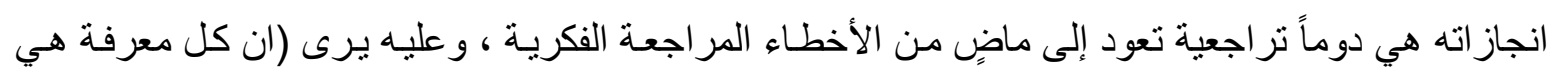

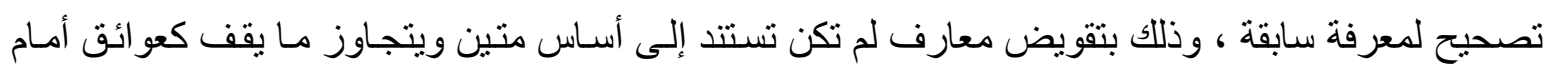

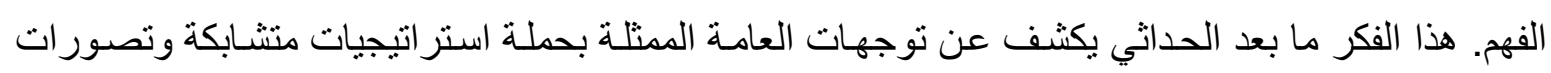

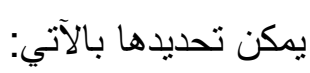

- رفض شمولية التفكير بافكار المنظومات المغلقة التي يكمن نموذجها في الآيديولوجيات الكبرى، وبالتالي

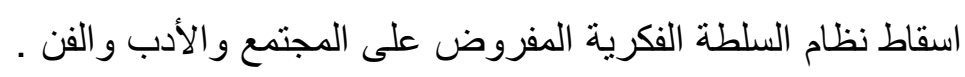
- رفض اليقين المعرفي المطلق ورفض المنطق التقليدي الذي يقوم على تطابق الدال و المدلول ، أي تطابق ولفي الأشياء والكلمات . 
- يتبنى تصوراً ابتمولوجياً انفصالياً فوضوياً للزمن ، ومنظوراً بر غماتياً للحقيقة وميلاً إلى الغاء الذات .

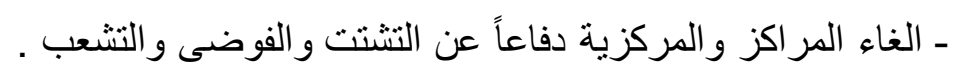

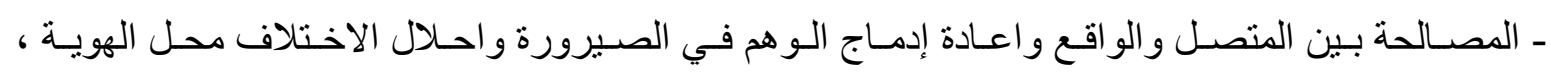

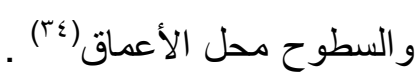

هذه سمات مـا بعد الحداثة التي تداخلت في رسمها تيـار ات فكريـة متتوعة تمثل مجموع ثقافـات

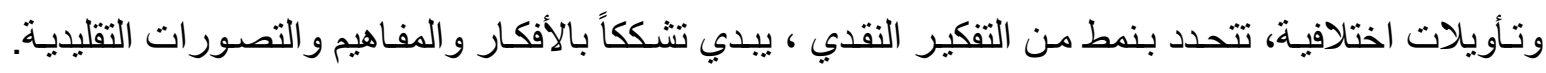

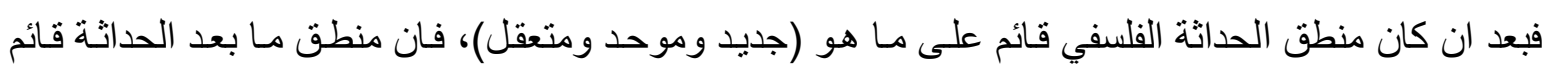

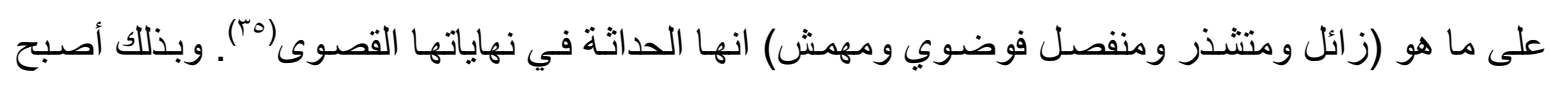

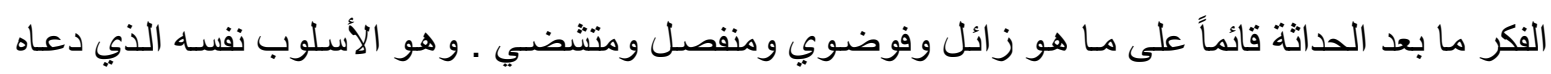

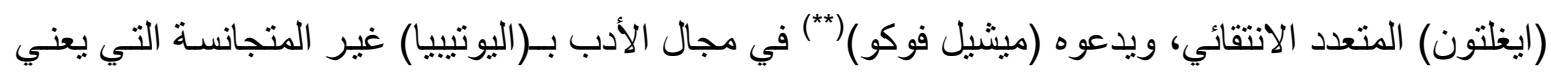

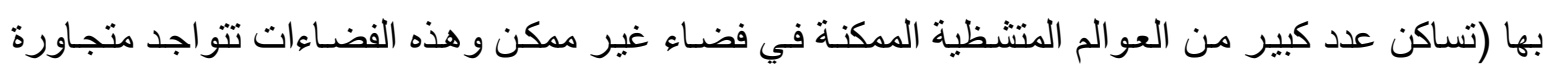

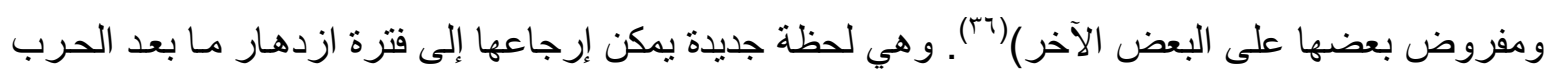

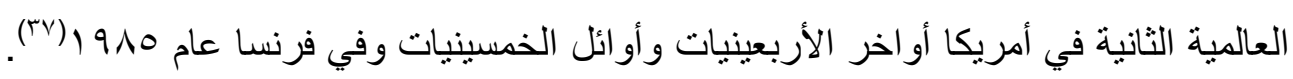

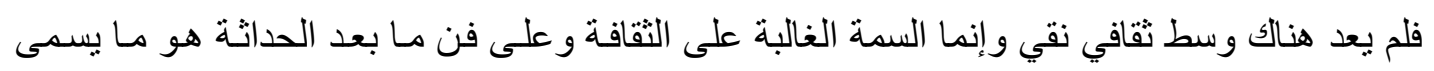

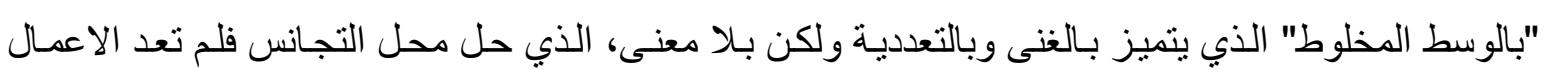

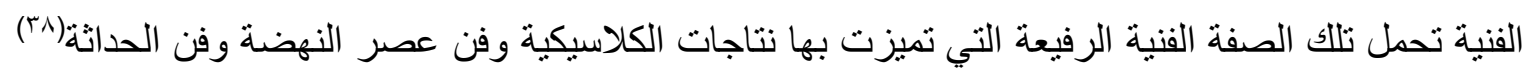
وفي سياق هذا التطور يظهر جلياً ان ما بعد الحداثة تعني خطاباً يمثل مرحلة ما بعد العبور إلى نظام

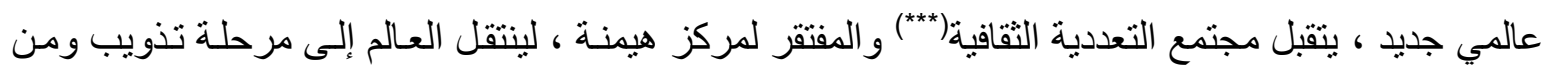

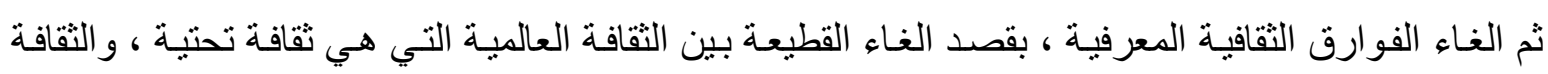

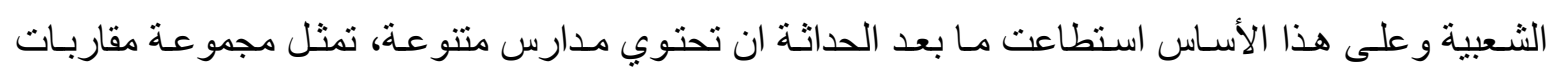

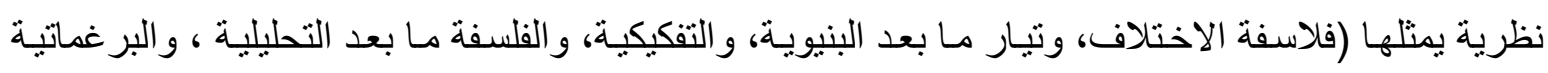

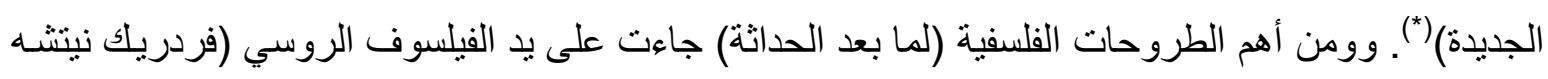

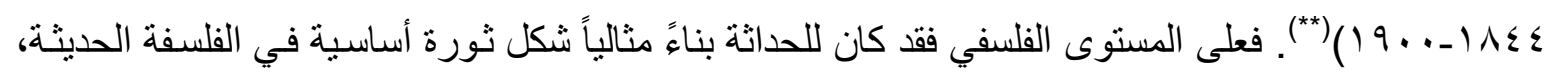

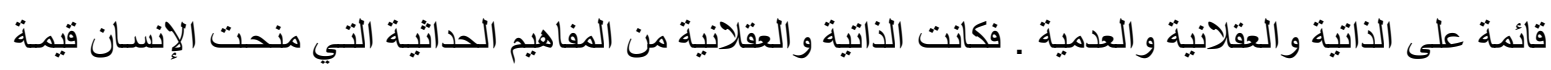

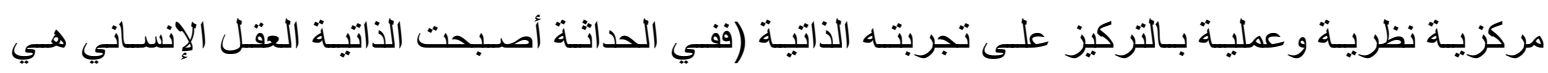
المؤسسة لموضوعية الموضوعات، بإخضاع كل معرفة إلى قدرة العقل بوصفها الذات المفكرة)(ب9). أما العدمية التي جاء بها فكر (نيتشه) فتعني التطرف في التعبير و غياب الأهداف الكبرى على نحو

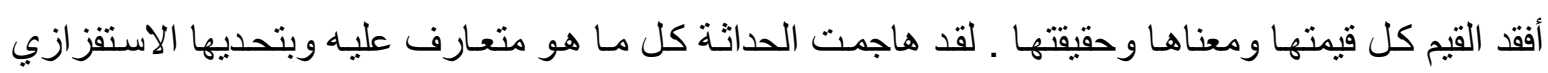

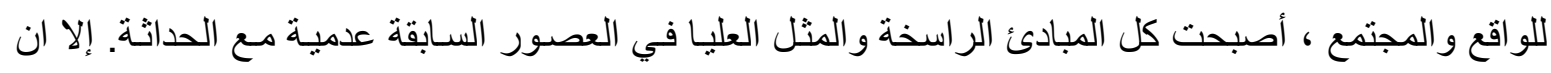

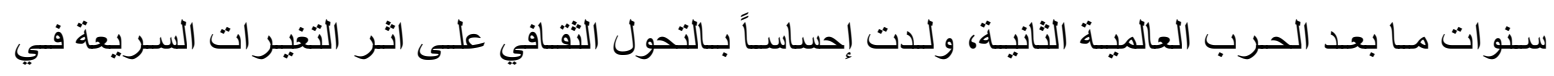
الخصائص الثقافية الثمولية التي مرت بها المجتمعات الغربية ، عندما تطورت اشكال جديدة من التجريب. 
وتجدر الإشارة إلى ان هناك اتجاهين فيمـا يخص مـا بعد الحداثة ، الاتجـاه الأول يؤيد القول بما بعد

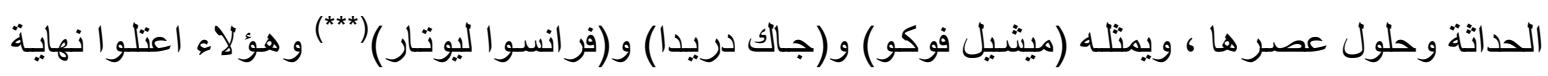

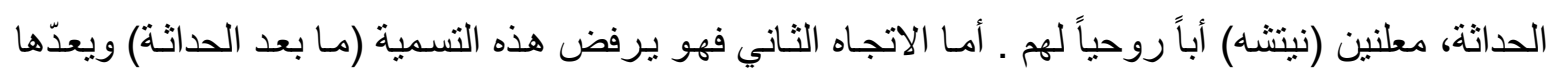
بدعة، ويمثله (هيرماس) و(فريدريك جامسون F.Gameson)(

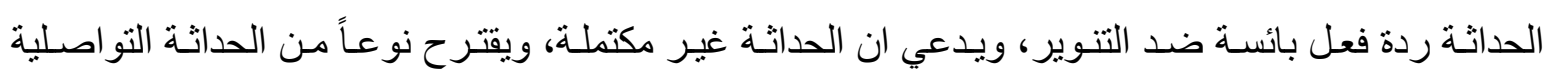

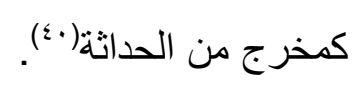

إن اتجاهات ما بعد الحداثة تظهر كرد فعل محدد باتجاه الأنماط السائدة في الحداثة ، و عملت على

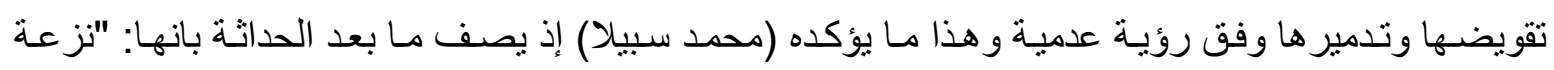

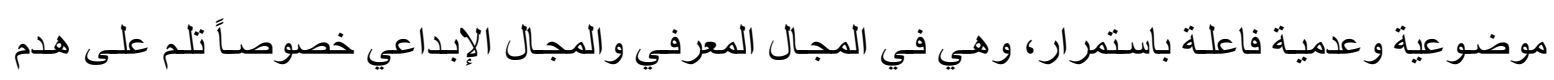

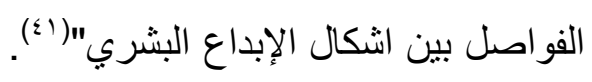

إن النقد النيتشـوي للحداثـة وعدميتهـهـ كـان البـاب الاوسـع للـخول عصـر مـا بعد الحداثـة، مـن خـلال التأسيس لتيار خاص به، سعى إلى تقويض بداهات العقلانية الغربية وكل القيم الملازمة لها عن طريق رفضـه

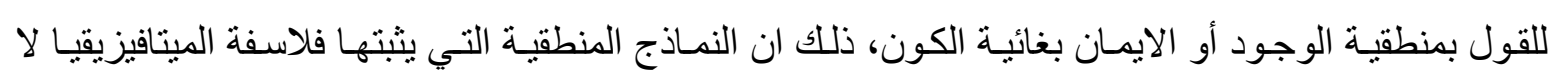
تعدو سوى ان تكون أو هاماً يصرون على معايشتها من اجل حفظ تماسكهم الوجودي(بـان. وبـذلك اسـهم نيتشـــ بتقويض الأسـس العقلانيـة السـائدة في طروحسات الحداثـة بوصـفها اسـتعار ات

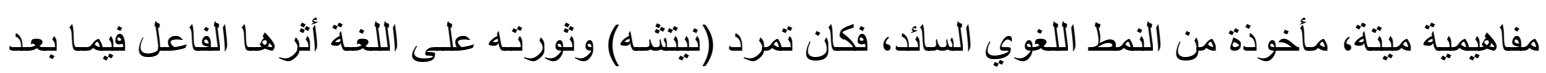
لـ(دريدا) هدماً لسلطة الكلمة في معقلها اللغوي، وذلك ليعيدها إلى مكانها الأصلي المختلف، بعدما اسقط منها صفتها المرجعية المحضة بالتمركز العقلي، ليجد ان اللغة هي مجموع اختلافات، فاللغـة هي الأثر الذي يتركه الاختلاف الآخر (ז).

هكذا تصبح اللغة شيئاً مغايراً بذاته، لأنها محكومة بانتظام نسقي يريد ان يقول شيئاً مغايراً عن الذي

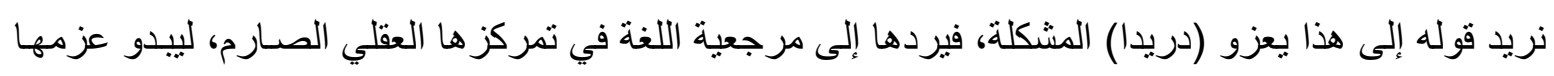

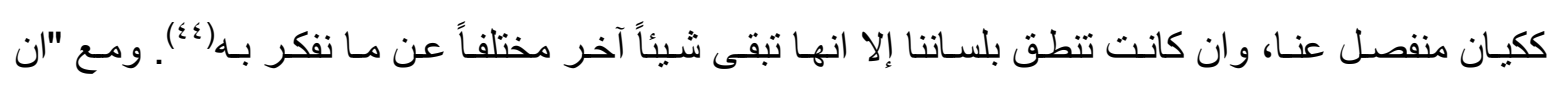

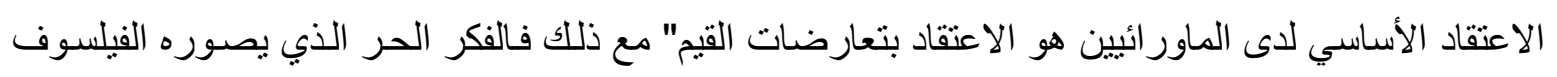

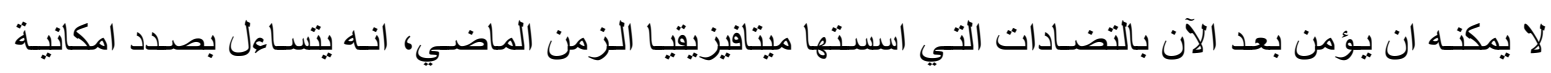

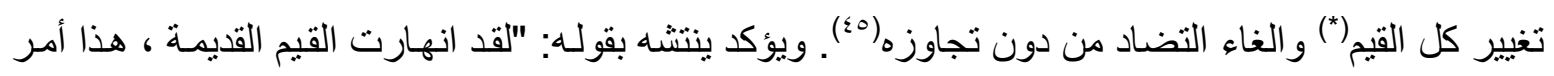
غير مأسوف عليه لنضـع لأنفسنا قيماً جديدة أخرى غير القيم الميتافيزيقية( كاء) ، يؤكد على انه لا قيمـة للقيم

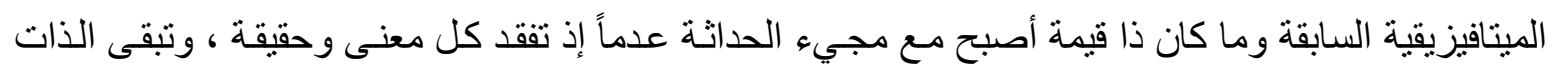
بوصفها سلطة (\&). وبـذلك فـان الـذات قـادت إلـى العقلانيـة ، ومـن ثم إلـى العدميـة، مـن خـلال رفض القيم والمعـاني اللاعقلانية ، ومن ثم الو اقع بطريقة فكريـة، ومن ثم محاولـة اختراع القيم و المعاني لاقامـة منظومـات جديدة تنظم الذهن و المجتمع ، بهذا فـان العدم يستحث العقل على الخلق الجديد، بمعنى خلق تصـور ات ومفاهيم 
ومنظومات متطورة ناسخة لما هو قديم(^). كما نجد ان (فرويد) كان أيضاً ضد الحداثة ومشروعهما العقلاني عندما رد العقل إلى دائرة اللامعقول بوصفه احد منتوجاته ، فالمعقول أصبح طريقاً للامعقول ، وهذا مـا دفع

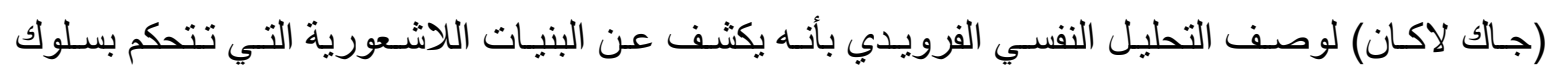
الإنسان(

فعندما تتضب نظرة العقل ما بعد الحداثة ، المشككة المواظبـة على العقل نفسـه تتولد العدميـة ، وهي

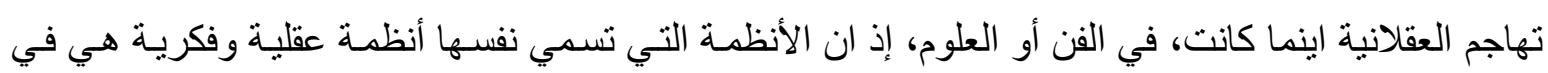

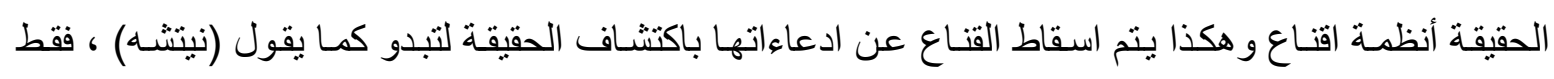

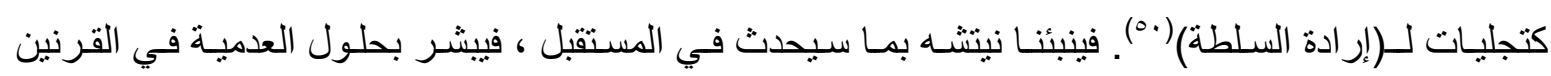
الآتيين ، إذ يقول في مقدمة كتابه الأخير (إرادة القوة) : "انمـا الرؤيـة هنـا هو تـاريخ القرنين القادمين ، فأنـا

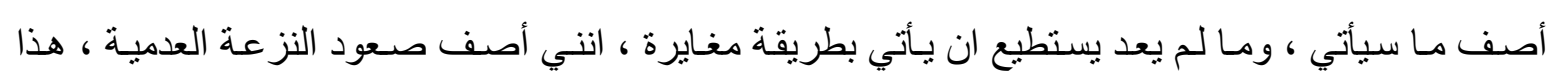

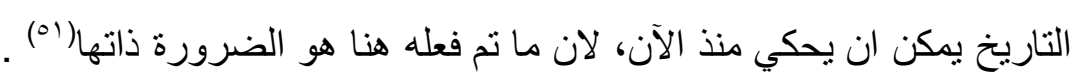
فقد ازدادت أهمية (نيتشـه) حينمـا اعلن توقعاته لاحداث مستقبلية في أوربـا ، وقد وقعت بالفعل في القرن العشرين ، مما يدل على نفاذ بصيرته في فهم الواقع الذي يعيثـه العـالم الغربي . بحيث رأى بـأن العالم الغربي سيشهد ظهور حالة من العدمية (حيث انعدام القيم وتلاشي أي معنى للحياة الإنسانية) وتهاوي نظسام العالم القديم وسيكون قرناً مشهوداً بحروبه الضخمة ، كما سيكون قرن الساسة على نطاق واسع وسيختفي فيه ونهايه

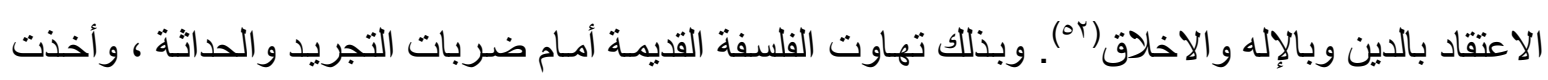

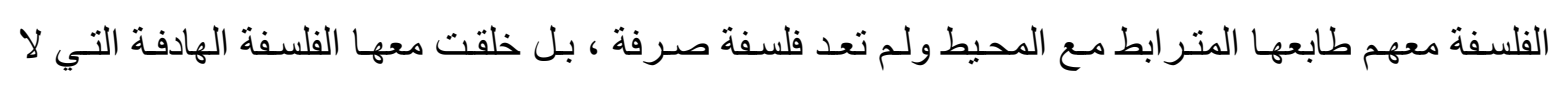
تنفصل عما يحيط بها من بيئة ومجتمع وظروف اقتصادية. كما خلقت من ناحية أخرى موجة من الثمولية

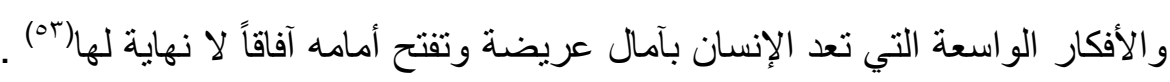
كما ان (نيتشه) ينظر إلى القيم على انها نسبية تخضع للتغيير و التبديل ، وان المعايير التي يقيسون بها الأمور ليست معايير أزلية ثابتة فهي فرضت عليهح بالقوة لا سلطان لهم عليها ، وهذه المعايير صنعها

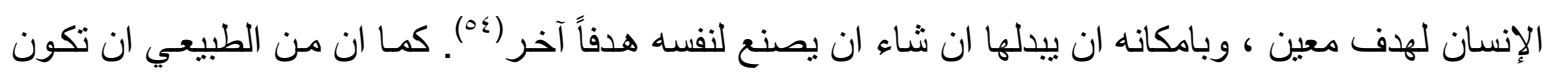

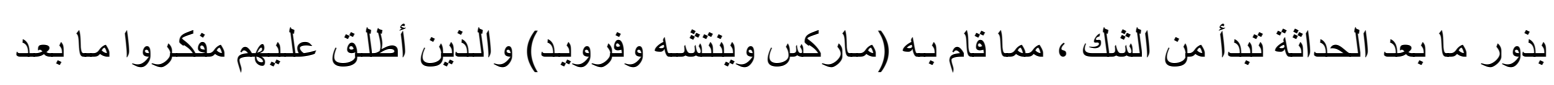
الحداثة لقب فلاسفة التشكيك فقد أسسوا لامكانية قيام تأويل جديد على حد تعبير (فوكو) فهم لم يضيفوا معنى جديداً على أشياء لم يكن لها معنى ، و إنما غيروا في الحقيقة طبيعة الدليل وبدّلوا الكيفية التي كان بإمكان الدليل ان يؤول بها(م) ــ وبذلك فـان الفيلسوف الألمـاني (نيتشـه) هو أول من بدأ بقطيعة فكريـة مـع العقلانية

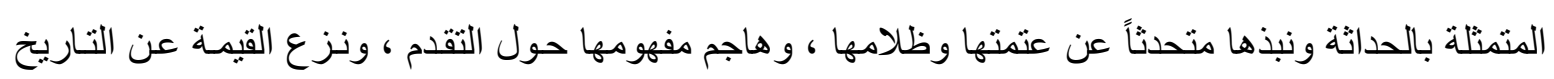

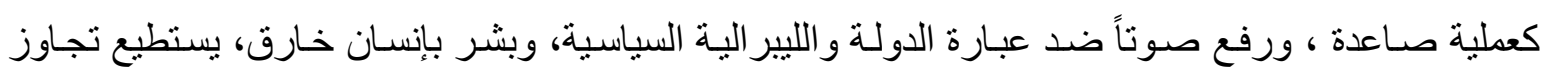
حدود عصره، والتعجيل ببزوغ فجر جديد للبشرية(07) ـ إذ رأى (بنتشـه) ان المفاهيم الكوزمولوجية ولية المتمثلة في التصورات التي تستهدف إعطاء وحدة وكلية ومغزى للتاريخ ، ما هي إلا مخططات للتفسير الميتافيزيقي

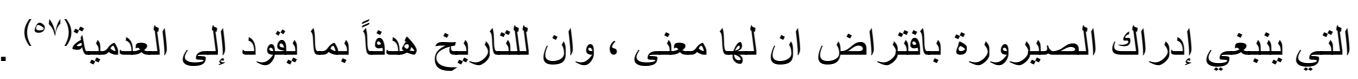


وبذلك فان الهزات الحضارية حسب توصيف (بر ادلي) التي تحدث بصورة منتظمة في تاريخ الفكر

و العلم والفن ، التي يقسمها إلى ثنلاثة أنواع ، منها مـا يكون (بسيطاً) ومتعلقاً بالموضـة التي نتأتي بها الأجيال

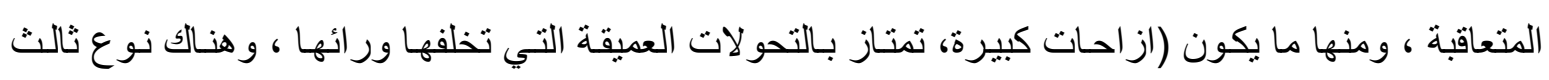
من الهزات يدعوه (المدمر الكاسح) حيث يقوض مساحة واسعة من البناء الحضاري و الفكري ، إلا انه يستتير الهمح لبناء البديل(0)

ويقدم (دريدا) التفكيك على انه أكثر مشاريع الحداثة وما بعد الحداثة ارتباطاً بـالمز اج الثقافي عامـة ، وبالمز اج الثقافي الأمريكي خاصـة ، فهو من ناحية امتداد لفلسفة (كانت الذي يقطع التفكيكيون معسه شوطاً كبير اً في تأكيده للذات ، ثم يتخطونـه حينمـا يدخلون مرحلة الثك في فنـل كل من الذات و العلم في تحقيق المعرفة اليقينية(09) ـ إذ يمثل (فوكو) مع مجموعة من الفلاسفة و المفكرين من جيله وهم ، (جيل دولوز ،

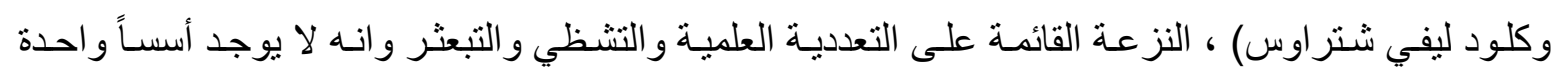
يمكن الانطلاق منها ، ويشبه (جيل دولوز) هذه الفلسفة بقوله : "ليس للتعددية ذات أو موضوع و و وإنما هي فقط ولنط

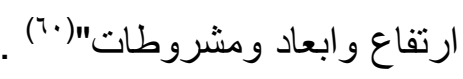

فجوهر التفكيك، فهو غياب المركز الثابت للنص والعمل الفني ، إذ لا توجد نقطة ارتكاز ثابتـة يمكن الانطلاق منها لتقديم تفسير معتمد أو قراءة موثوق بها ، بل ما هو مركزي أو جوهري في قر اءة مـا ، يصبح

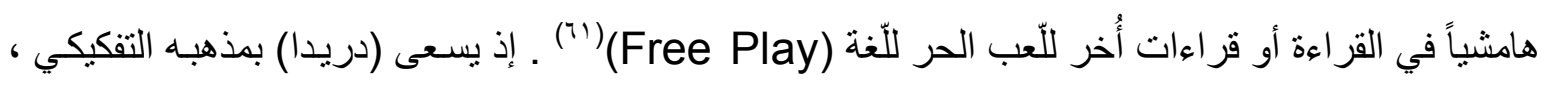

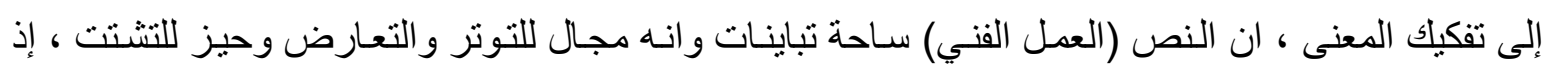

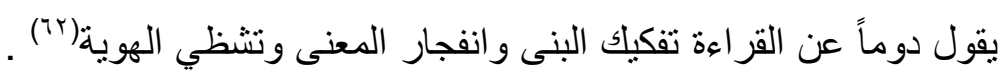
و اتجه نقده للمر اكز الغربية نحو الأسس التي تتمحور حول فكرتين أساسيتين هما : التمركز حول العقل ، وميتافيزيقا الحضور(*) ، إذ يطمح إلى تفكيك كل مر اكز الدلالية وبؤر المعاني التي شكلت حول هذين

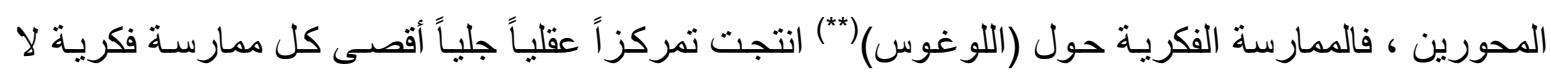
تتمثل للشروط ، و انتج نظاماً مغلقاً من التفكير ، أما فكرة الحضور فإنها تو اكب اللوغوس وتمثنل مبداًُ راسخاً مفاده ان الموجود يتجلى بوصفه حضوراً أي ان الوجود الكائن يتمظهر حضوره بين الأشياء(rآ) وبالرغم من هذه الخصائص التي تتصف بها النظريـة التفكيكية فان (دريدا) يصر على عدم ارتباط مشرو عه بالعدمية بل برى ان قر اعته التفكيكية ــ التقويضية ، قر اعة مزدوجة تسـعى إلى دراسـة الفن دراسـة

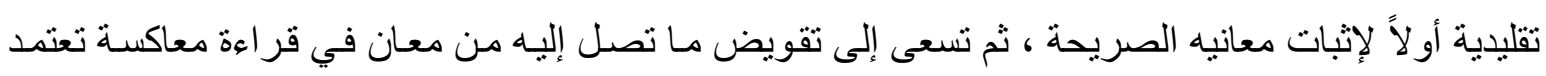

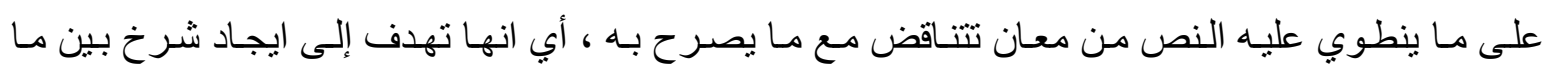

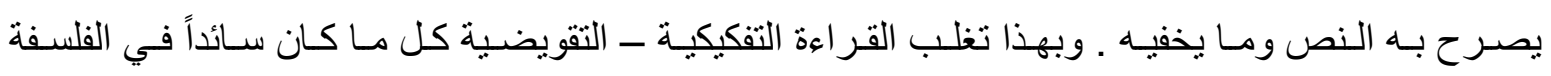
الماور ائية ـ ويرى (دريدا) ان الفكر الغربي قائم على ثنائية ضدية عدائية يتاسس عليها ولا يوجد إلا بها مثل

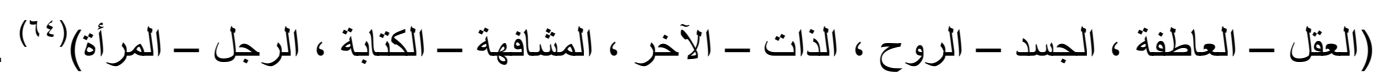
أمسا الاخـتلاف - والارجـاء (Aefferance) على غـرار كلمـة (Ladifferance) التـي نحتهـا (دريدا) من الكلمة الفرنسية (Differ) ومعناها (الارجاء) ، و الكلمة (Defferance) بمعنى اختلاف وتحمل 
معنى الاختلاف (في المكان) والارجاء (في الزمان) . ويرى دريدرا ان المعنى يتولد من خلال اختلاف دال

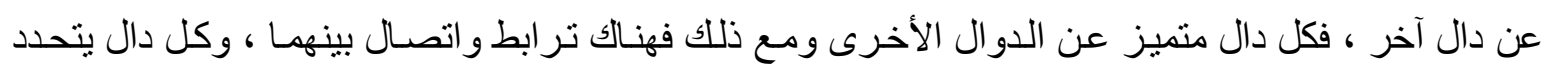
معناها داخل شبكة العلاقات مع الدو ال الأخرى ، لكن معنى كل دال ، لا يوجد شكل كامل إلا في ايـة لحظة (فهو دائهاً غائب رغم حضوره) و هكذا (فالاخترجلاف) عكس الحضور و الغياب بل يسبقهما(70) ظهرت البنيوية كمنهج فكري على انه رد فعل على الوضع الذي سـاد العالم الغربي في بدايـة القرن

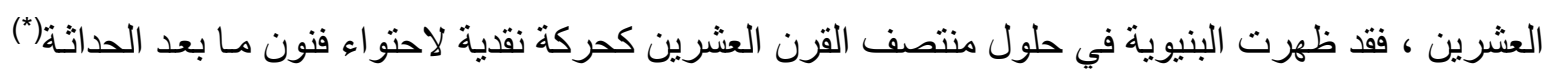

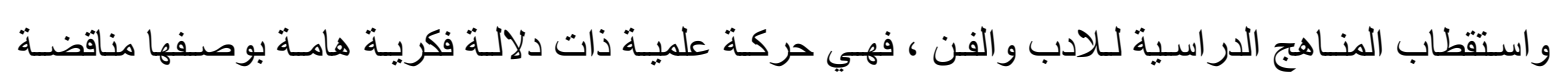
ومناهضة للتفكير القائم على التجزئة والتفتت، أو ما يسمى بالتفكير الذري، نسبة الى الفلسفة الذريـة التي تقول بأن العالم يتكون من ذرات منفصلة ، أي ان الاتجـاه العام للبنيويـة ، هو النظرة الكلية التي تبحث عن النظم

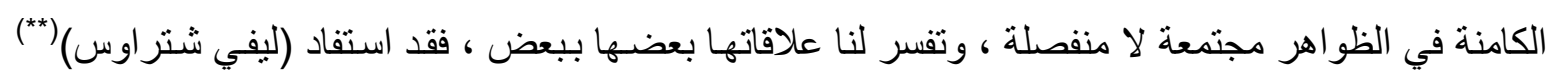
من أفكار (سوسير)(*** في اللغة فأنشأ لنفسه منهجاً يرصد النظم الكلية التي يسميها الأبنيـة أو التر اكيب القائمـة

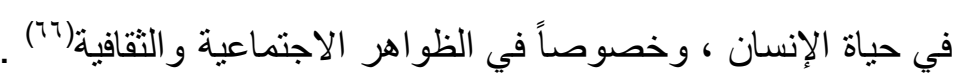

فكل ظاهرة في النظرية البنيوية يمكن ان تشكل بنية ، فالاحرف الصوتية بنية ، و الضمائر بنيـة ، إلا ان المو اقف البنيوية تتلافى لتشكل مبادئ عامة مشتركة منمنلة بالسعي إلى ايجاد ثو ابت في كل مؤسسـة بشرية

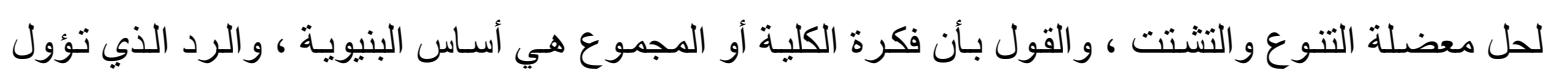

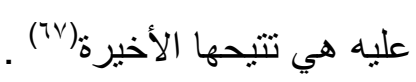

فقد عرفت البنية انها نظام مكون من مجموعة من الأجزاء أو (العناصر ، المكونـات) ذات الطبيعة

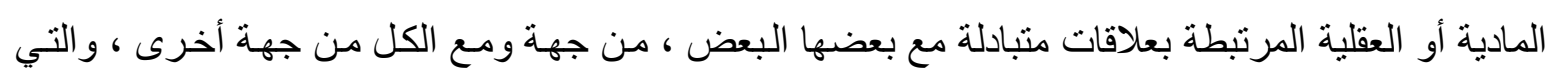
تحدد بذلك الخصائص الجوهرية وفقاً لقو انين حاكمة ، وبما يخلق تنظيمات تتصف بانها تو اصلية بين الأجزاء (تصور وظيفي) ، أو تتصف بها (نتائج التطبيق) نوع من الفروض المنطقية كمـا تمكن التمييز مـا بين البنية السطحية التي تعنى بالخصائص والعلاقات المباشرة المحسوسـة المدركة بين عناصر ظـاهرة مـا كونها تمثنل الناتج النهائي في عملية تكوين الظاهرة ، وبين البنية العميقة التي تعنى بالخصائص و العلاقات الثابتة الكامنة

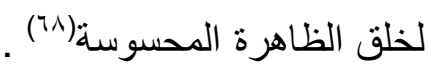
فالبنية تعمل (كنظام تحويل يشمل على قو انين ثلاثة هي الكلية والتحول و التعديل الذاتي)(79). وقد عرف (كلود ليني شتراوس) البنية بقوله : "ان البنية بكل بساطة تحمل أولاً : طلابع النسق أو النظام ، فالبنية

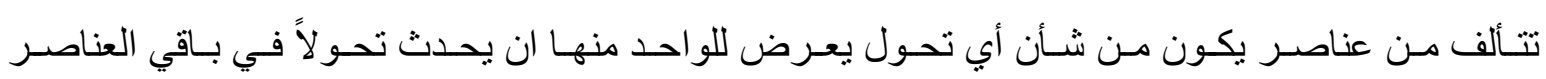

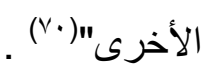

و على حين أطلق (ينتشه) في نهاية القرن الماضـي (موت الإلـه) ، فلقد جاء فلاسفة البنيويـة في هذا العصر لكي يعلنوا (موت الإنسان) ، ولكي ينادوا - على اقل تقدير - بأن الموجود البشري هو الإله في

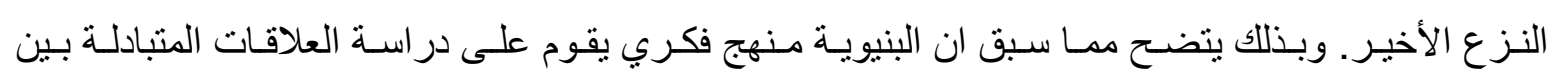

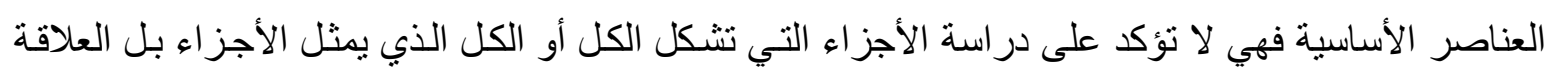




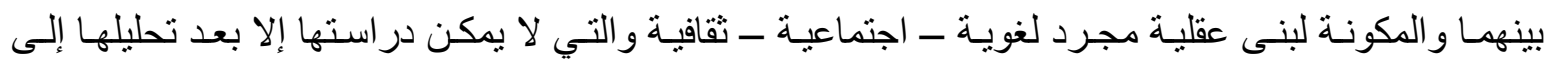

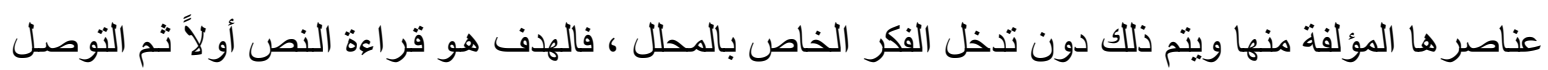

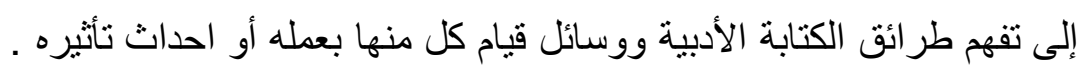

ففي الفكر ما بعد الحداثي ينقلب مفهوم ليهدف إلى خلخلة العالم ذاته و الطعن في عالم الهويـة و التثـابه

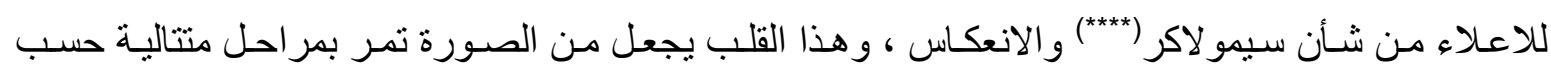
تصنيف (بورديار) و وعلى النحو الآتي :

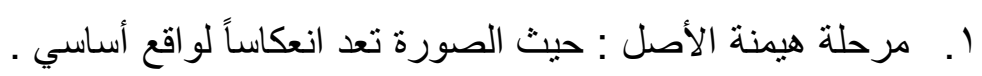

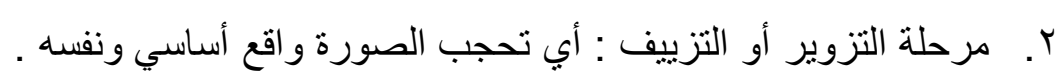

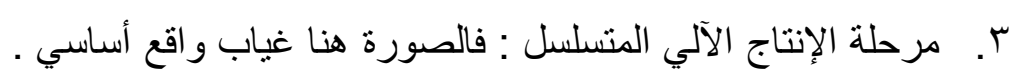

ففي المرحلة الأولى تتضمن نظاماً للحقيقة يتم فيها الانتقال من الرموز الني تخفي شيئاً وراء ظاهرها

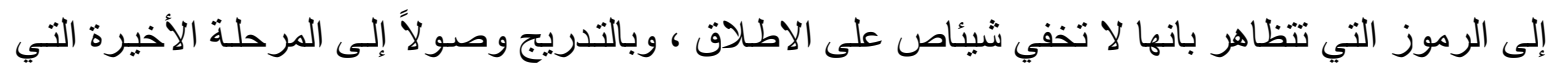

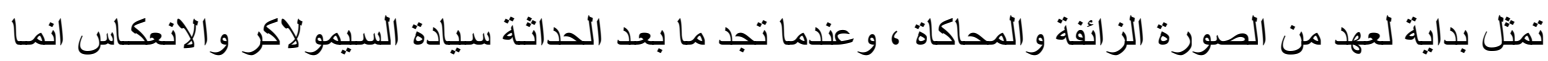

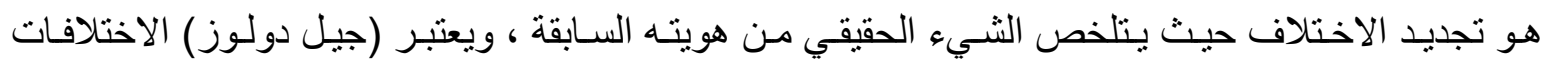

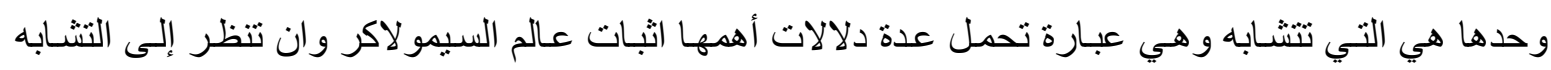

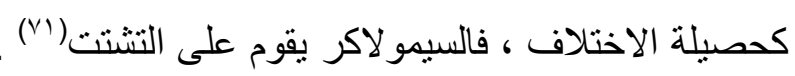

\section{r. التمولات المعرفية في الفز المفاهيمي}

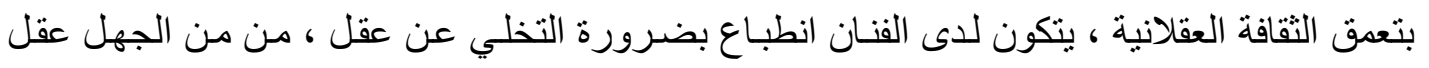

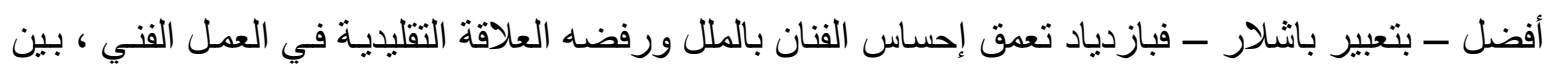

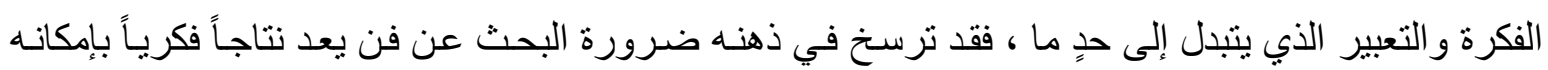
ترجمة الأفكار والتعبير عنها بوسائل وخامات منعددة قادرة على خدمة تلك الأفكار ، متطلب ذلك الكت استبعاد

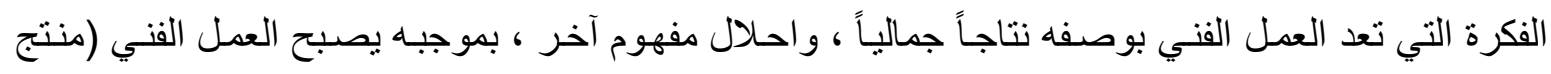

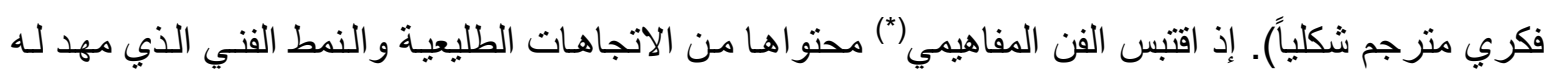

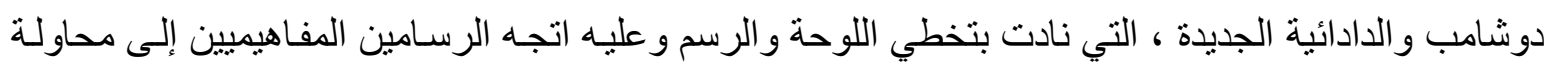

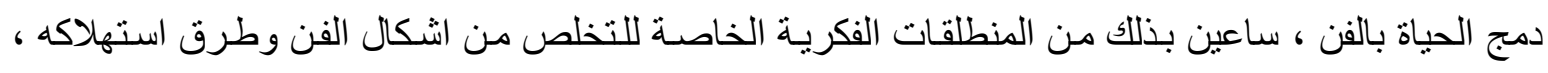

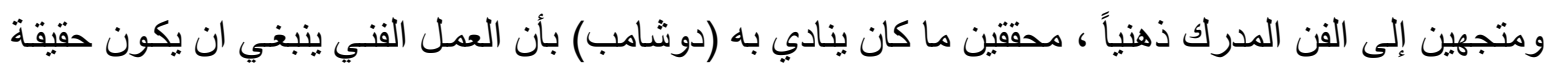

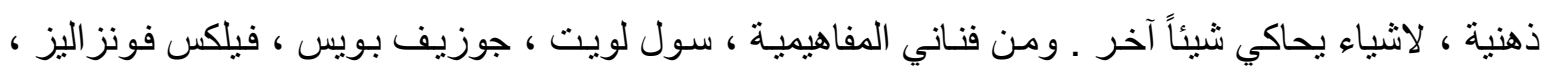

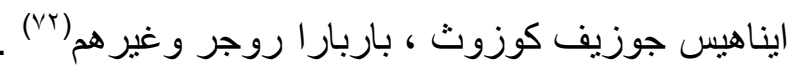

فترى الباحثة ان الفن المفاهيمي هو محاربة التقاليد الفنية فهو ينطلق من اتجاهـات فكريـة خاصـة

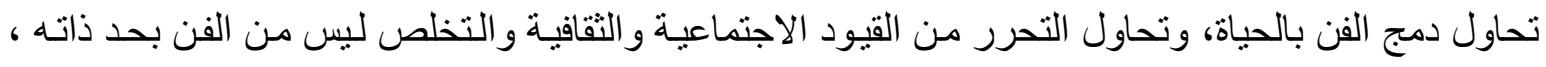
بل من اثكاله النقليدية وطرق استهلاكه ، بمعنى ان يمتتع الفنان عن تقديم عمله كسلعة ممكن الاستفادة منها 
عن طريق بيعها في سوق الفن ، ويعمد إلى ابراز الو اقع أحياناً كقيمة جمالية، والاساس في ذلك هو الفكرة

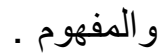

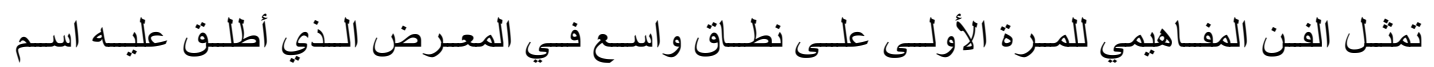

$$
\text { سنة } 1979 \text { في متحف ليفركوس في ألمانبا(V) (Conception) }
$$

و هذا النوع من الفن هو حدسي يتضمن كل العمليات الفكرية دون ان يكون لـه أي هدف ، وهو لذللك

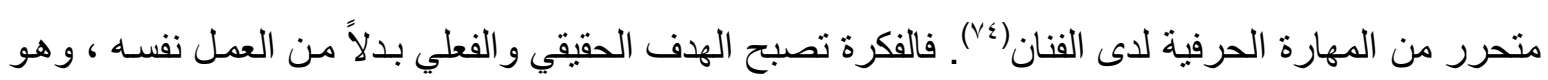

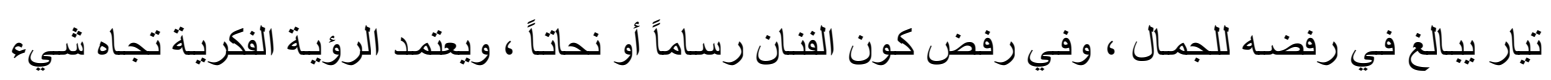
معين للتطلع إليه على انه عمل فني (vo).

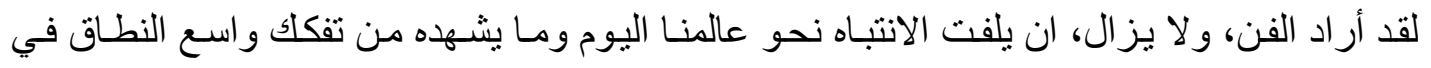

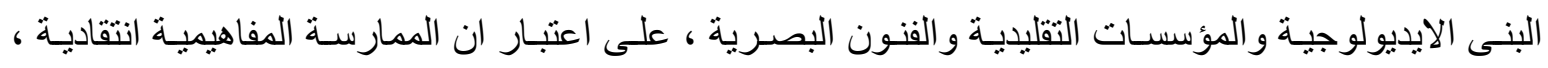

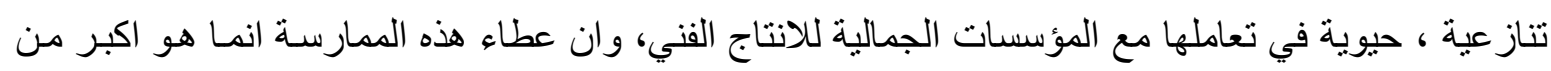

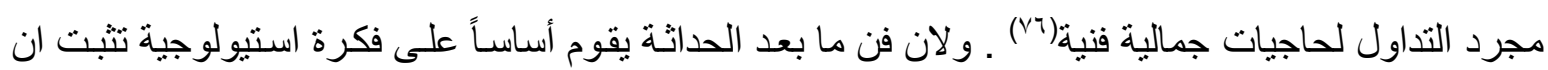

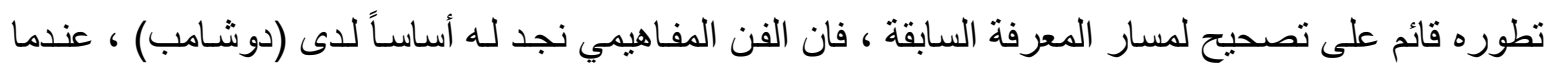

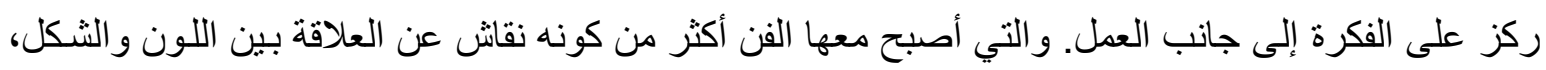
بل إلى نوع بو ازي النصوص المكتوبة الني تعد بمثابة رسائل خفية يو جهها الفنان إلى المتلقي ، مثلها باعمال فنية ميزتها الرئيسية هي الفكرة - الدفهوم لتصبح (الفكرة) آلة لصناعة الفن .

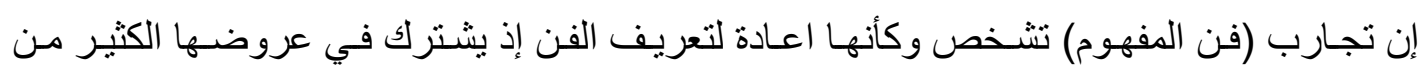

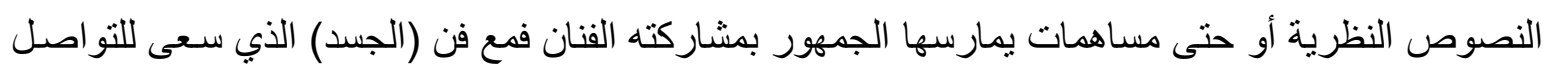

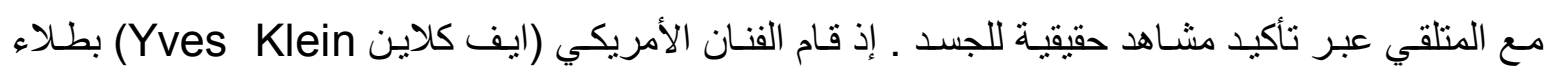

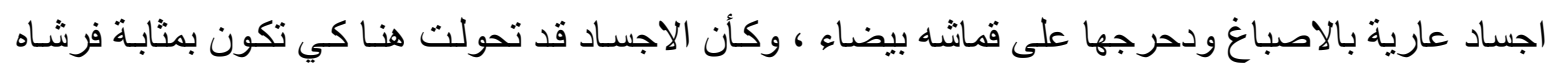

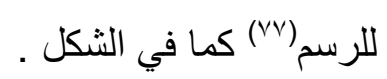

فقد تضافرت جهود (دوشامب) مع جهود كل من (ايف كلاين وبيرو مانزوني Piero Manzoni)

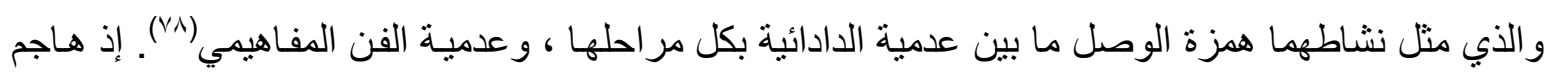

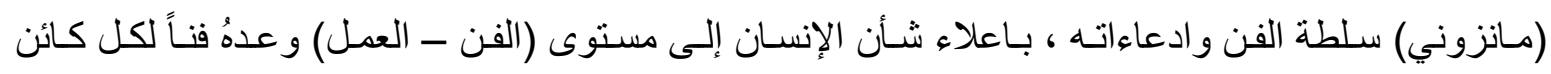

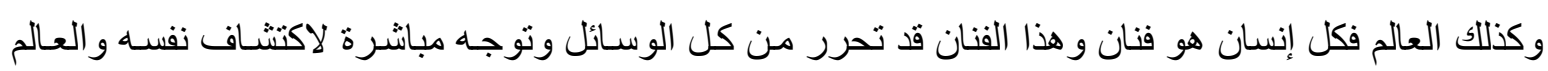

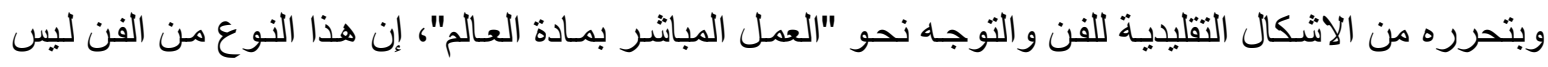

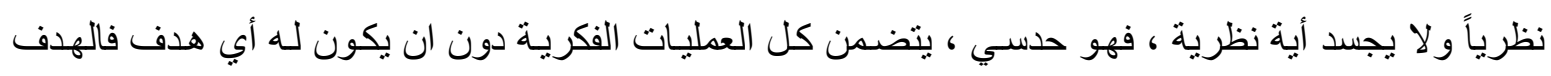

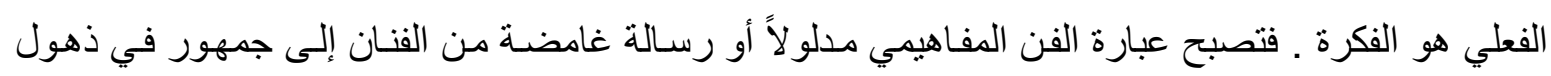

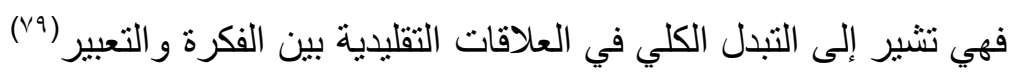


وبذلك اهتم الفنان المفاهيمي بما يوسع من المعلومـات والموضـوعات التي لا يمكن جمعها في شيء

و واحد بسـهولة ، ولكن يمكن توجهها عن طريق المقترحات المكتوبـة والصسورة الفوتو غر افيـة باستعمال اللغـة

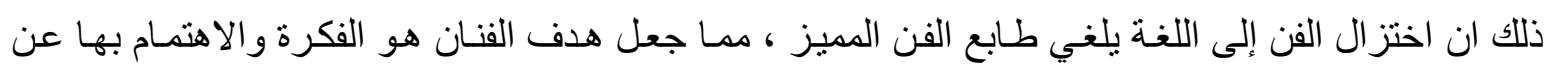
طريق ترسيخ الحسات الذهنية ، أمسا بالنسبة للمتلقي فيستلم الإشـارة الجمالية والتي تتميز وفق هذه هذه الاعمـال

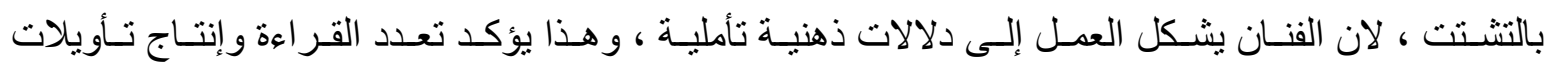
متعددة:) (^)

إن فكرة الفن - لغة ، لم تكن فكرة مبتكرة لدى الفنان ما بعد الحداثة لطرح مفهومـه الفكري ، إذ نجد

جذور ها عند (رينيه ماغريت) في لوحته (خداع الصور) شكل ( (1) ، فقد كتب أسفل صورة الغليون عبارة "هذا ليس غليونـاً بمعنى ان مـا تمثلـه الصورة ليس بالضـرورة ان يكون الغليون المستخدم للتندخين عـادة ،

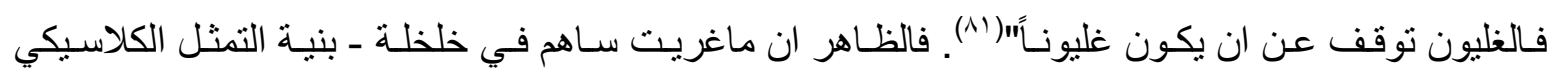
وبأكثر من صيغة ـ ولعل أهم هذه الصيغ الاقحام الثاسع بين الثيء المكتوب والجانب المصور في اللوحة

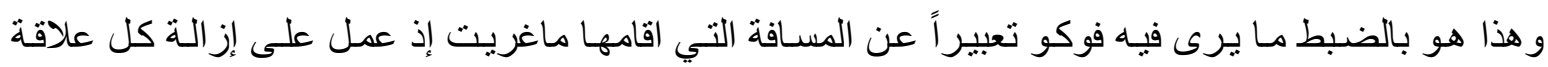
تمثلية بين "المكتوب" و"المرئي" ـ فلدى ماغريت ان الصورة المرسومة ليست نسخة للواقع بل هي صورة للتفكير لأنها لا تعكس نموذجاً خارجياً بقدر ما تعكس صورة الفكر نفسه ، وبذلك مهدت محاو لات (ماغريت)

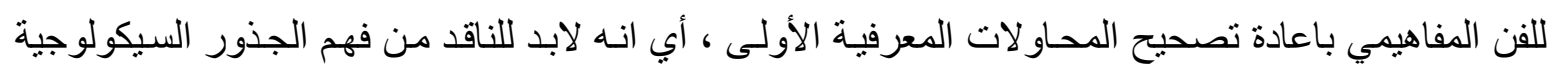

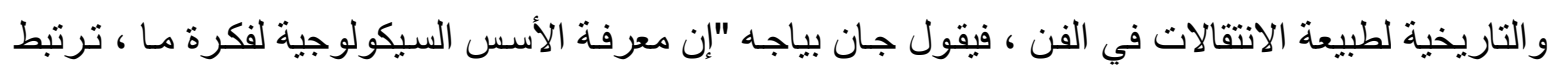

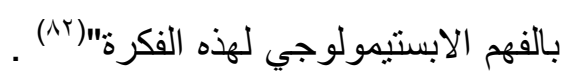
و الفكرة التي تتتج العمل في الفن المفاهيمي لابد ان تكون أكثر فعالية ذلك انها تشترط التزود بـالكثير

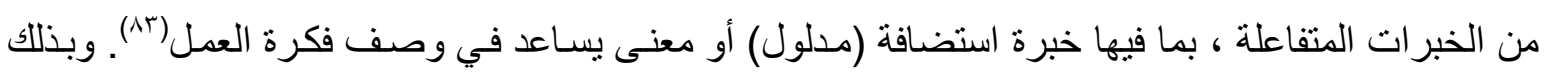
فمن خلال منهجي اللغة والصورة ، يصبح الفن مجالاً لتأمل عقلي نقدي ويتحول إلى تحليل ايديولوجي على هلى

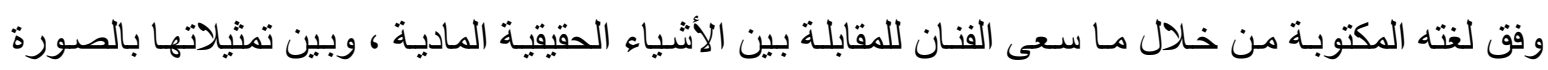

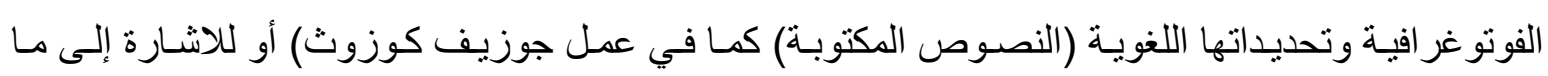

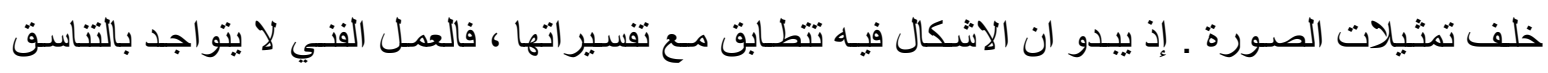

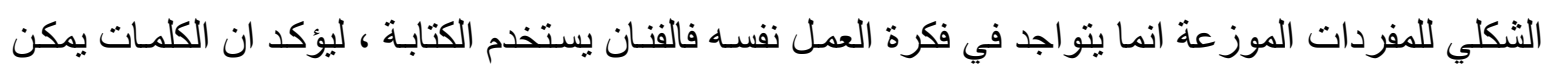

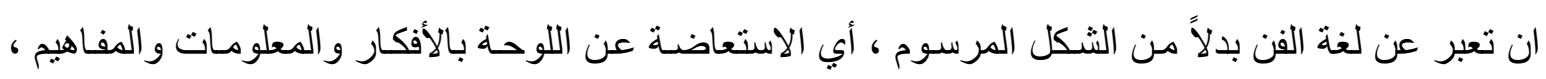

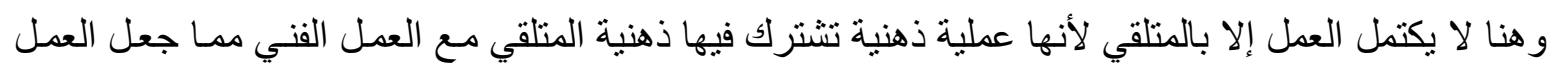
الفني يحتمل أكثر من قر اءة واحدة فهي تقرأ بسرعة وتستهلك بسر عة مما جعل كثرة التداول خلال وسـائل

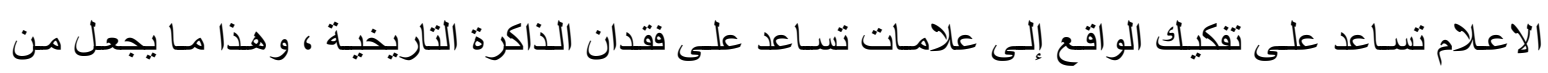

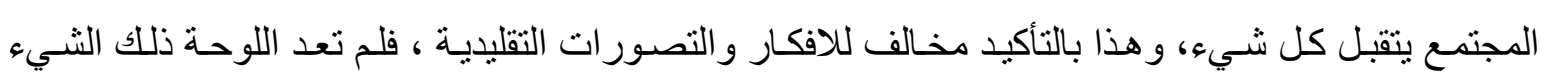
المتعـالي التي يصـعب على فئسات المجتمع الوصـول إليـه إذ أصـبحت تعبر عن توجيهـات العصـر مـا بعد الصناعي و الاستهلاكي. 
وبذلك تعود بدايات الفن المفاهيمي إلى محاو لات (مارسيل دوشامب) في مطلع القرن العشرين و التي تأصلت في الستينات بأن الفن يقوم أساسـاً على ترجمة الفنان لفكرته باستخدام أي وسيط ير اه مناسباً للتعبير عنها و الحريـة في اختيـار أي نـوع من الخامـات التي تخدم الفكرة ، مـن دون التقيد بالأسس الفنيـة التقليديـة و المألوفة ، على أساس ان العمل الفني ليس منتجاً جمالياً ، بقدر مـا هو منتج فكري ، مستخدماً التطور التقني و التكنولوجي غير المحدود ، مع ثقافة الصورة الصناعية منطلقين من مفهوم ان الفن الحديث و المعاصر لابد

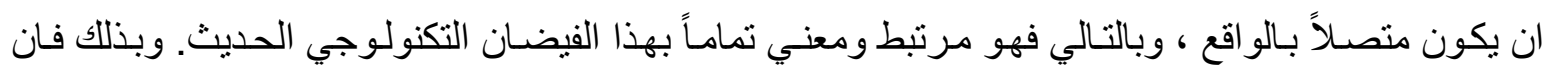

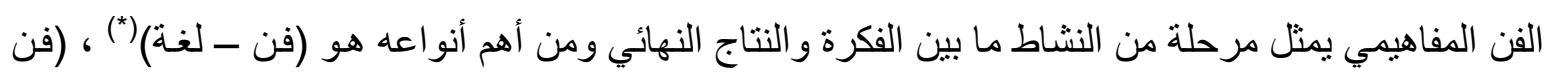

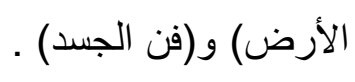

\section{المبمث الثاني- الابعاد البنائية للمورة الكتابية في الفن الفغاهيمي كيمي}

إن الصورة واللغة في نظر كوزوث تلتقبان عن طريق الكتابة وهي الوسيلة التي تجعل الكلمة مرئية

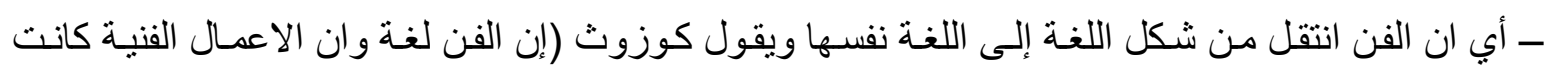
حروف الجر بالنسبة للغة...)(^). . ويؤكد الفنان المفاهيمي (جون بالديسـاري): (إن فكرة الفنان هي الأسمى،

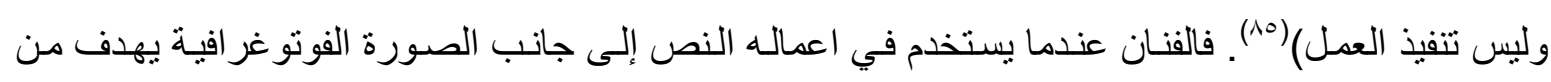

ذلك التأكبد على فكرته المفاهيمية شكل(r).

إن عملية القر اعة التي تختص بفكرة العمل هي مرحلة مهمـة ، لان الفنان يقوم بوضعها ضمن سياق

الفن البصـري ليتحول الأخير إلى فن ثقافي فلسفي علمي ولغوي ، فلا يتبقى من الثـيء الفني إلا تحليله

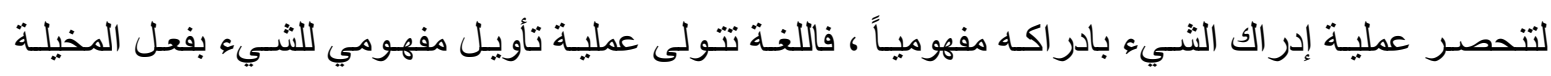
المعرفية التي تتشط لتركيب الافتر اضات المتنوعة . ففي عمل جوزيف كوزوث (Joseph Kosuth) ابرز ممثلي هذا الاتجاه تتراجع ثنائية (الفن - عمل) فالعمل الفني في نظره هو الثنائية القائعـة بين (فن - لغـة) فهو يشرح مـا يريد التعبير عنه من خلال المقابلة بين الثيء الحقيقي وتمثيله (الصورة الفوتو غر افيـة) وتعريفه

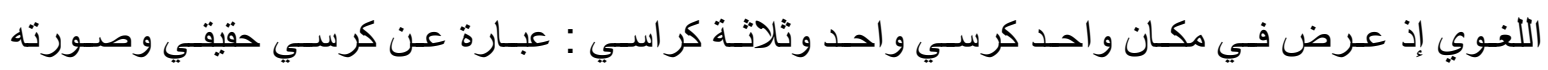

$$
\text { الفوتوغر افية و التعريف اللغوي لكلمة كرسي كما وردت في القاموس كما في عينة ( ) . ل }
$$

ففي الفن لغة، ومن خلال منهجي اللغنة والصورة ، "يصبح الفن مجالاً لتأمل عقلاني نقدي ويتحول

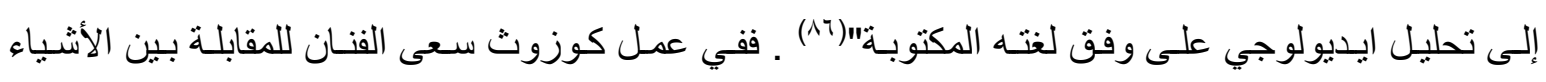

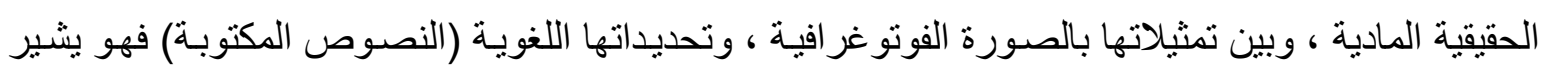

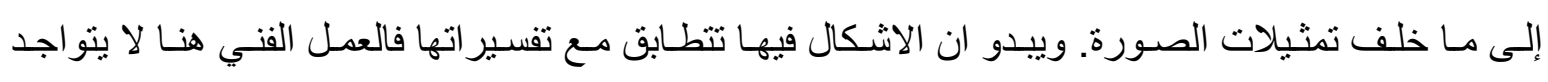
بالتناسق الثكلي للمفردات الموزعة انما يتو اجد في فكرة العمل نفسه فتركيز الانتباه على المعلومـة المعجمية اللغوية للكرسي ، وهو انتباه انتقائي له دوره في نقل المعلومة إلى مستوى اعمق و أكثر دلالة .

فالأعمال الفنية في نظر (كوزوث) كانت فرضيات مقدمة ضمن مضدمون الفن كتعليق على الفن ،

مما جعل الفنان يستخدم الكتابة ، يؤكد ان الكلمات يمكن ان تعبر عن لغة الفنان بدلاً عن الثكل المرسوم وهذا

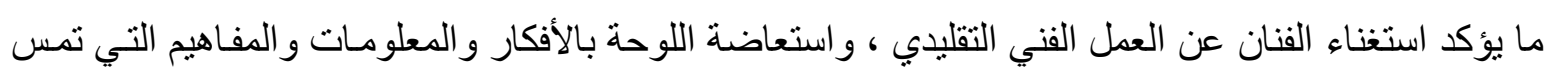


الفن(Av). و هذا مـا يشير إلى تقويض قدسية العمل الفني فاللغة أصبحت شيئًا مغاير اً بذاته ومغاير اً محكومة بانتظام نسقي يريد ان يقول شيئًا مغايراً عن الذي يريد قوله أي انها تحمل دلالة أخرى مختلفاً عمـا نفكر بـهـ و هذا ما يؤكده دريدا في هدم سلطة الكلمة باسقاط صفتها المرجعية . فالكلمات تحمل دلالة علميـة خالصـة لأنها كلمات قائمة على التو افق وليس على الرابطة اللغوية .

كمـا ان الأفكار و الصـور المستتنارة في ذهن المتلقي هي التي تثير الكتابـة والصـور التي يـدركها

المتلقي، لان المفاهيميون بؤمنون بأن الحقائق هي معارف ذاتية تخص المتلقي ، و لا يمكن تعميقها بل إثارة

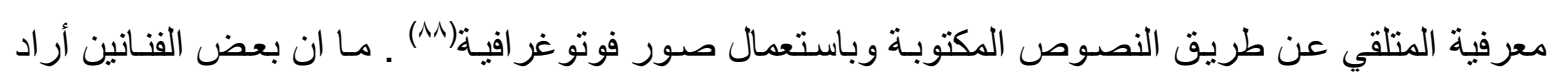
توسيع نطاق الفن المفاهيمي بتوجيهه نحو تفسير ات تعتمد اللغة على نحو كلي ، وهذه اللغة تبنى على نظام خاص يفقد به الفن اتصاله بالو اقع ، ويقى الهدف الرئيس للفنان هو إيضاح المماثلة بين الكلمـات المتثـابهة في

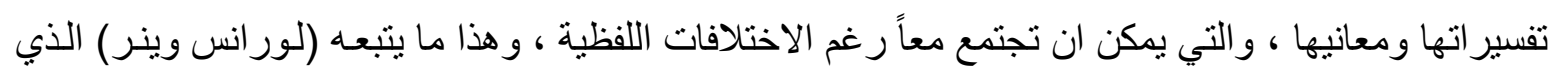
يجمع بين كلمهة (Pices , bits) (وكلا الكلمتين تعنيـان القطع الصـغيرة) كما في عينة (r) ، ويؤكد خـلال

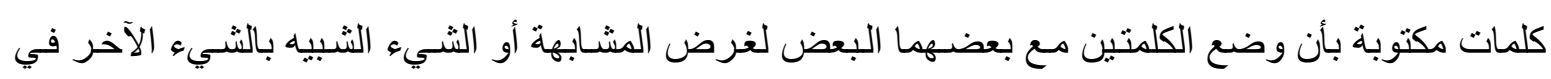

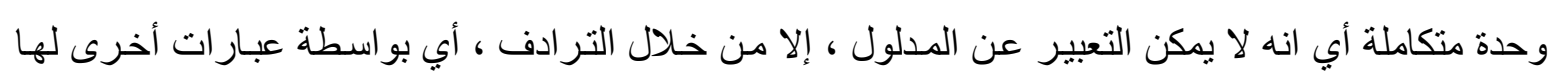

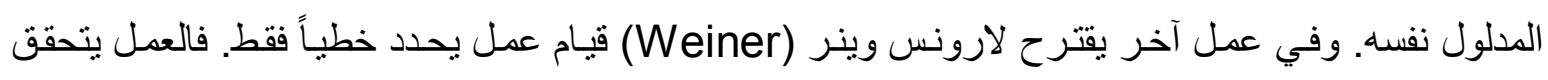
مثلاً بمجرد كتابة (أطلق النار على شلالات يناغر ا) ثم يوضح وينر بأنه يمكن للفعل ان يتحقق أو لا يتحقق إلا

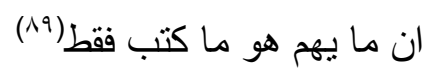

\section{: Land Art فز الأرض}

تطورت نشاطات الفن المفاهيمي وانتقلت إلى نوع آخر يعرف بفن الأرض أو فن البيئة ، وهذا النوع

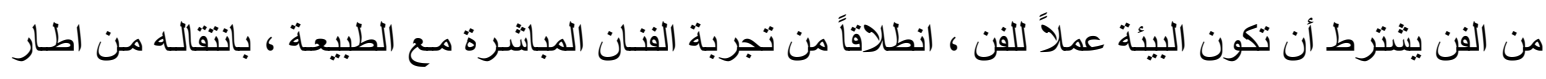

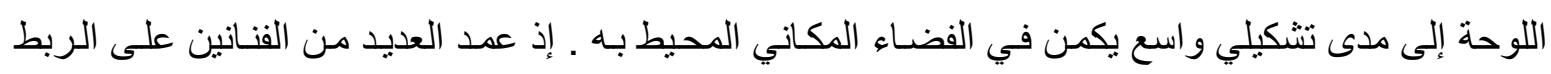
بين الأرض ومعطياتها وبين موقفهم الروحي ، (لأن الفنان لم يعد يكتفي باستخدام الأرض كموقع مكاني

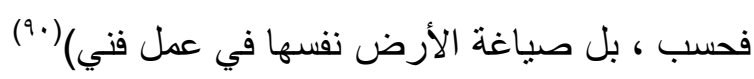
إن تصـاميم فن الأرض في الطبيعة استخدمت مواد مختلفة ، مثنل أحجار ، أور اق، أثنجار، الثلوج، الأنهار، البحيرات، الرمال، و الجبال، ولم تكن تشير إلى أهداف فنانين ممتدة على نطـاق واسع فحسب، بـل

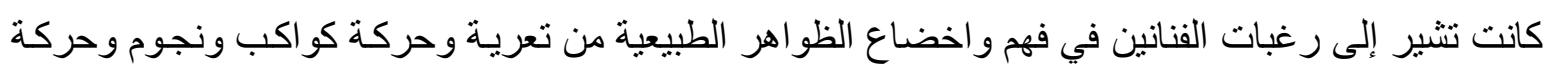

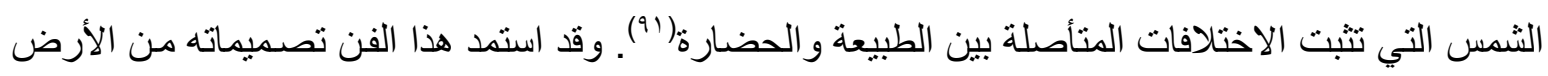
بعـد أن تحـرر فنـانو الأرض مـن الاسـتوديو وحسالات العـرض فأصـبحوا قـادرين علـى أن بينشـئو ا بمسـاعدة

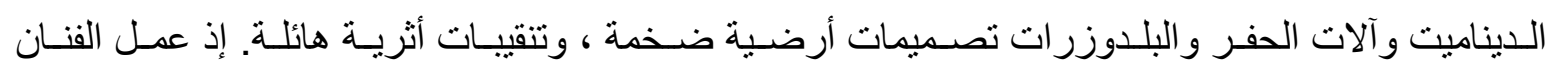
(روبرت سمثسون) مباثـرةً على الأرض ، فوجـه فيها مـا يوحي لله بأفكار جديدة. ففي عمله بحيرة الملح

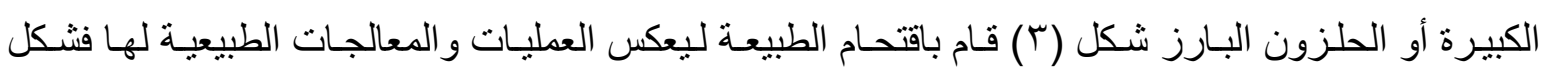
حلزونـاً ضـخماً يتحرك مـن حافـة البحيـرة باتجـاه المركز . فهو يصـور الجـدل بـين البنيـة المنطقيـة والنظـام 
التجريبي بين طبيعة المو اد (التراب و المـاء) ويعلق (سمثسون) على الطبيعة الاستعارية للعمل بقوله: (العقل

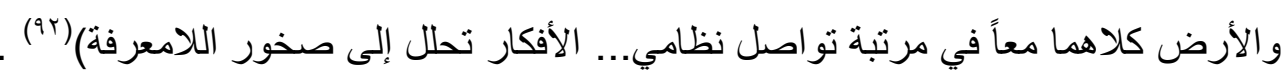

فز الجنسد

أما فن الجسد فقد توصل الفنانون إلى مـا عُرف بـ(فن السلوك) أو (فن الجسد) باعتمـاد الجسد مـادة أساسية للعمل الفني فهو لا يقام أي هدف للعمل الفني سوى العمل "يلغي المسافة الفاصلة بين الو اقع وترجمته

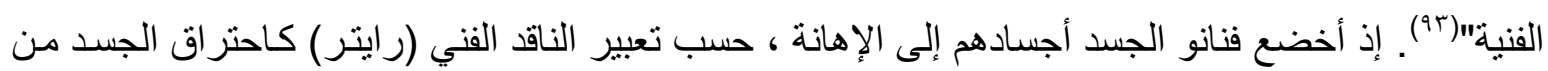
حرارة الثمس، أو علامات ونقتشات عُملت على الجسد ، مما يجعل الجسد الإنساني مساوياً للمسادة في وجودهـا وفي ادر اكها البصـري إذ أن الجسـ يمثل سـلعة استهلاكية(؟9). و أيضـاً تنـاول الجسـ الإنسـاني بوصفه نتاجـاً جمالياً وثقافة جديدة تؤكد انحر اف الفن وابتعاده عن التقاليد الحداثويـة ، إذ عمل الفن المفاهيمي على تفكيك مشرو عية الخطاب الفني للرسم ومعالجته بأساليب تعتمد فن الجسد سياقاً معرفياً وجمالياً . ففي العمل الفني

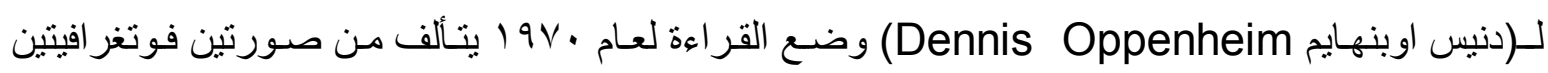

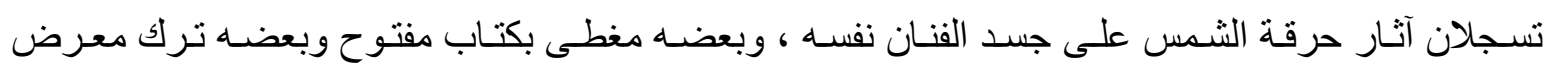
للشمس ـ هذا النوع من التعبير غالباً ما يوصف كفن جسدي ، و اضطر (اوبنهايم) إلى أن يعرض نفسـه وفي

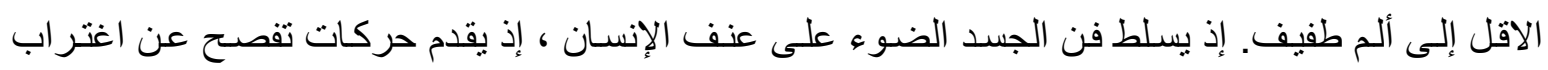
الإنسان العميق ونزوع الذات إلى مطلقية التعبير(90.

\section{مؤشرات الإطار النظري}

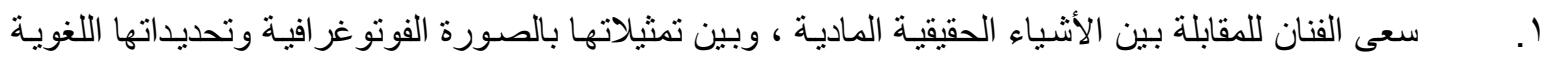

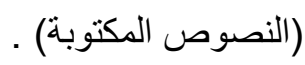

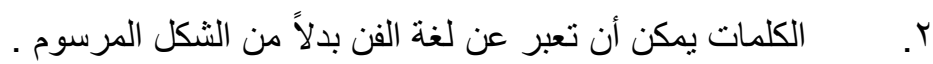

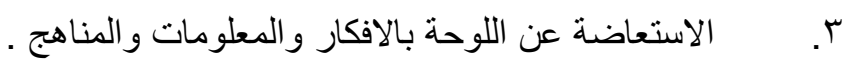

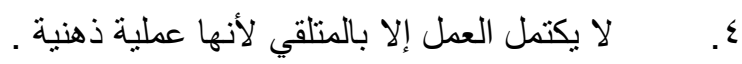

○. ترجمة الفنان لفكرته باستخدام أي وسيط ير اه مناسباً للتعبير عنها و الحرية في اختيار الخامات التي تخدم الفكرة .

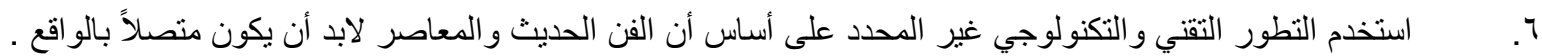

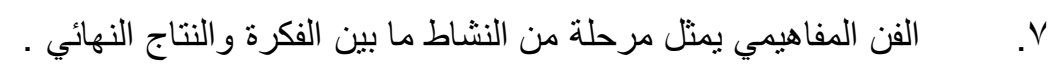

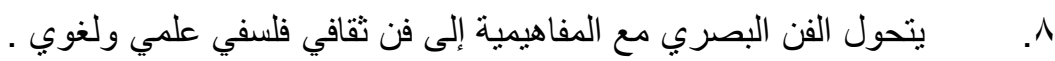

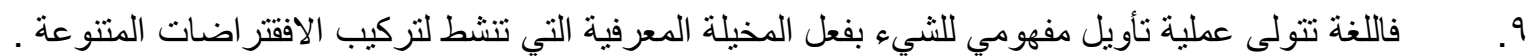

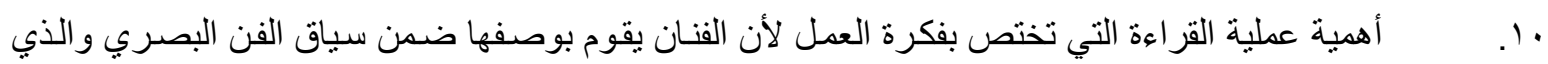
يتحول إلى فن ثقافي فلسفي علمي ولغوي فلا يتبقى من الثنيء الفني إلا تحليله لتتحصر عملية إدر الك الثيء بإدر اكه مفهومياً. .

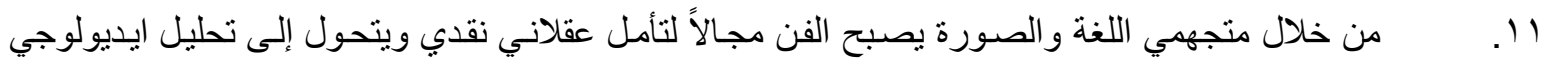
على وفق لغته المكتوبة .

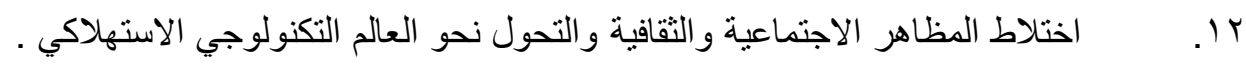

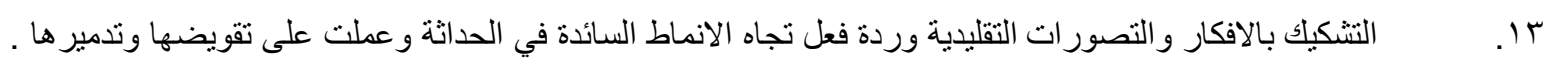
ع ا. . لم يعد الفنان ما بعد الحداثوي تحكمه قو اعد فالفنان يعمل بلا قو اعد ليصنع قاعدة أخرى لعمله الفني . 
ما بعد الحداثة تحول تاريخي شامل نحو شكل جديد من اشكال الثقافة المعاصرة التي داهمت المجتمعات

الغربية منذ منتصف القرن العشرين .

العبور نحو عالم التكنولوجيـا والنزعة الاستهلاكية وصناعة الثقافـة وهي عو الم سريعة التبدل و الزوال

.17

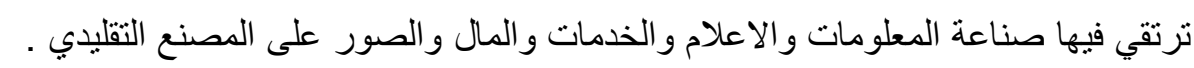

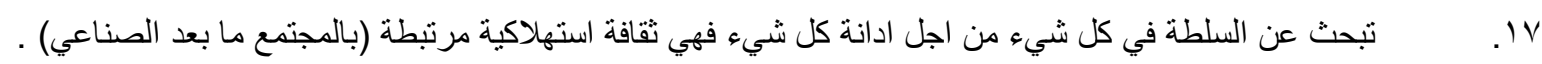

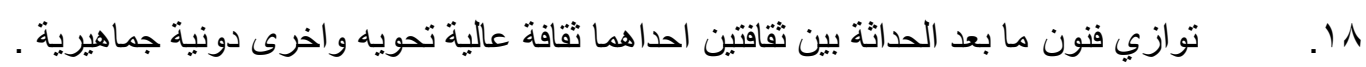

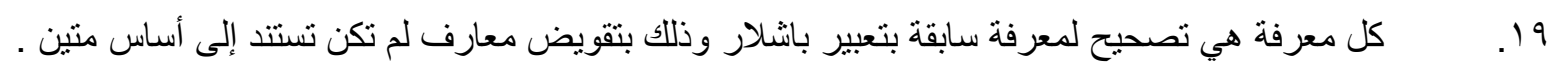

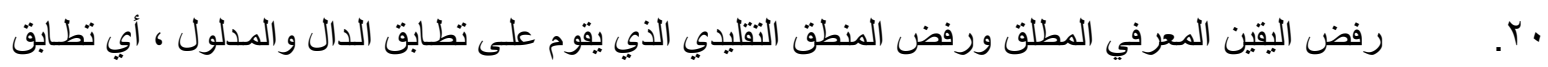

الأشياء و الكلمات . أبات

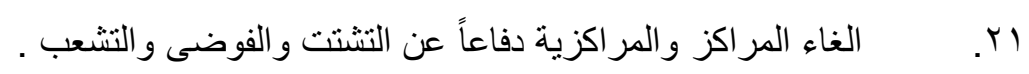

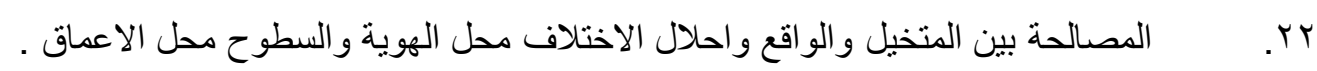

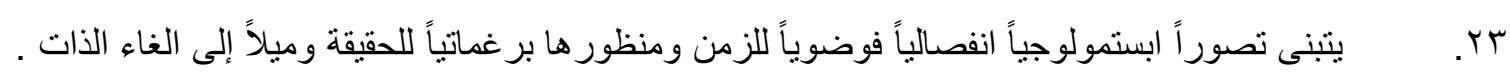

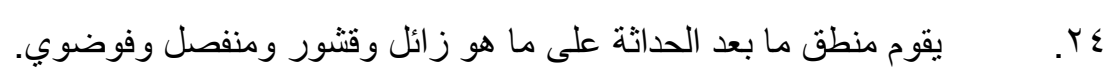

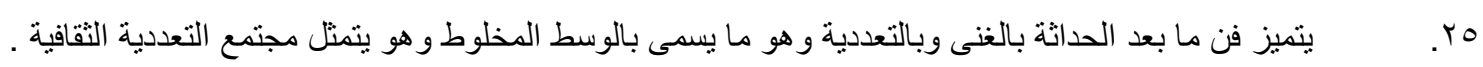

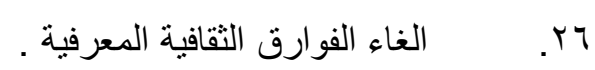

rV

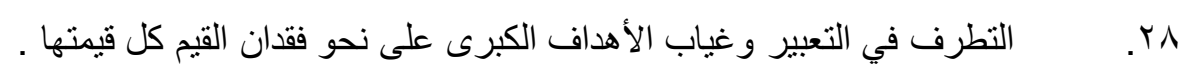

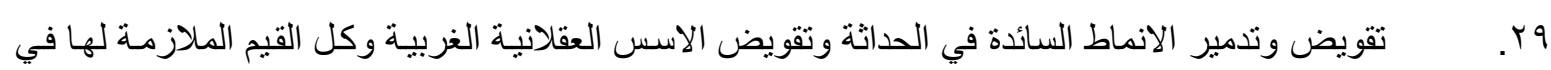

طروحات الحداثة بوصفها اشعار ات مفاهيمية قيمة .

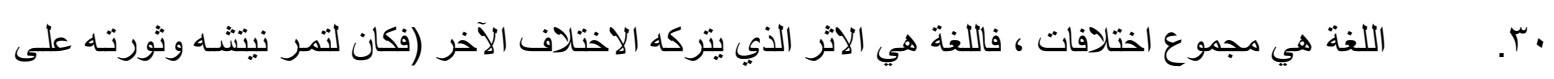

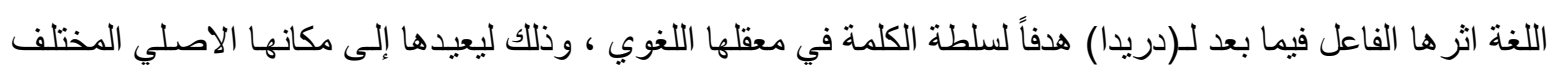

، بعدما اسقط منها صفتها المرجعية المحضة بالتمركز العقلي) .

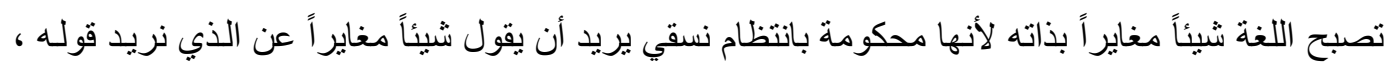

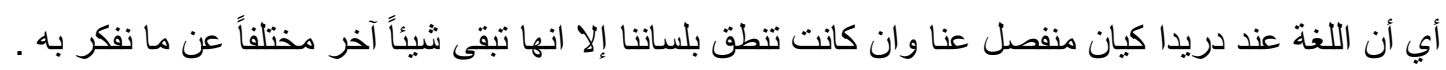

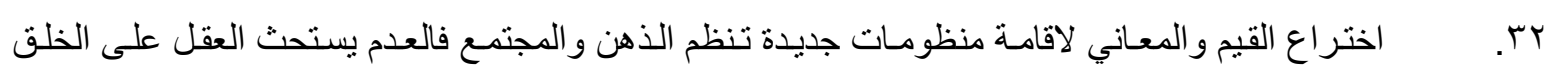
الجديد بمعنى خلق تصور ات ومفاهيم ومنظومات منطورة ناسخة لما هو قديم .

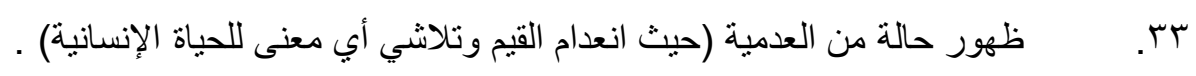

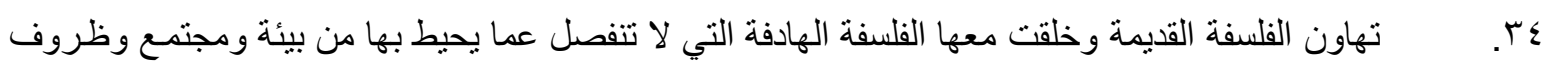
اقتصادية مع موجه من الثمولية والافكار الواسعة .

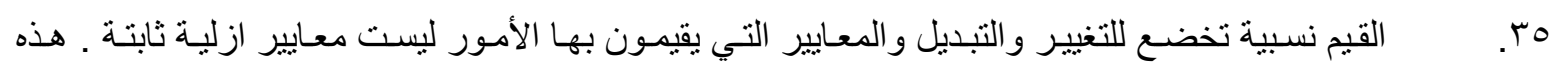

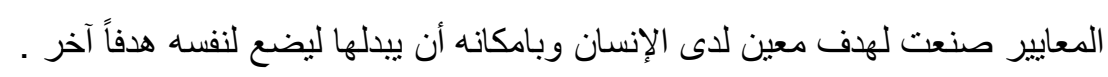

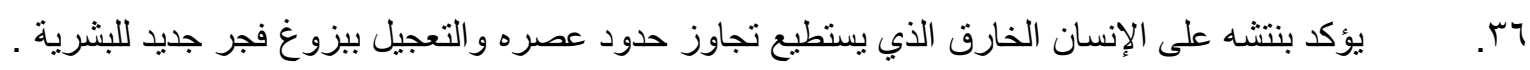

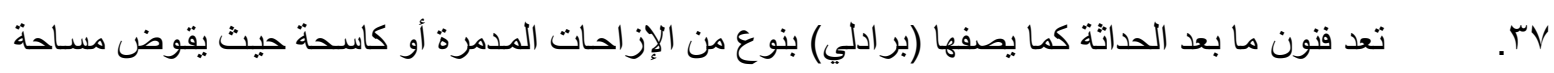

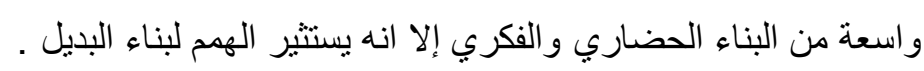

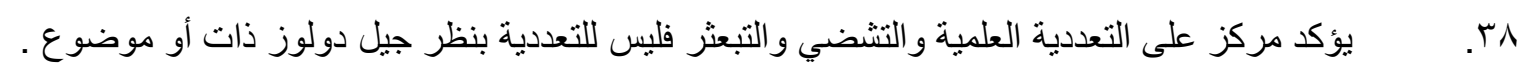


9 ب. غ غياب المركز الثابت للنص و العمل الفني ، إذ لا تجوز نقطة ارتكاز ثابتة

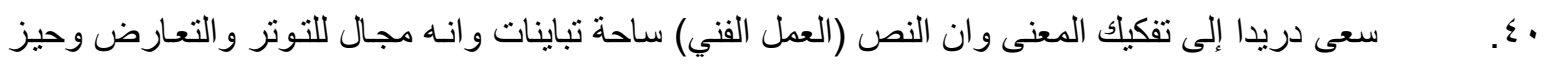

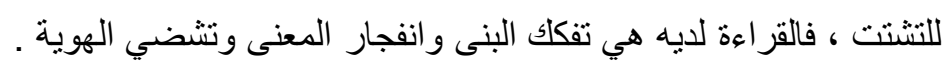

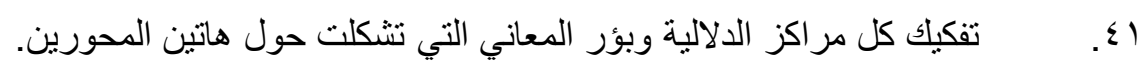

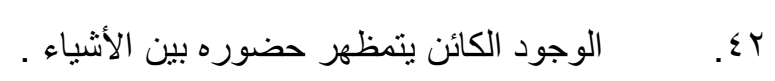

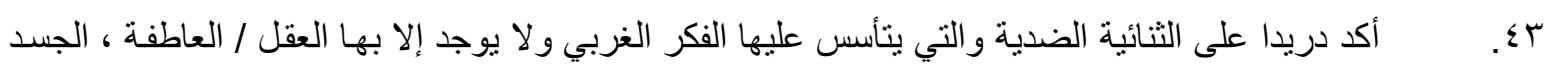

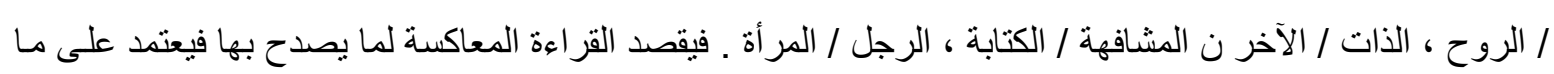

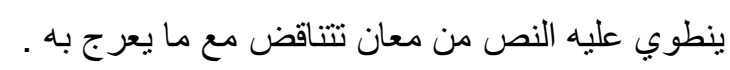

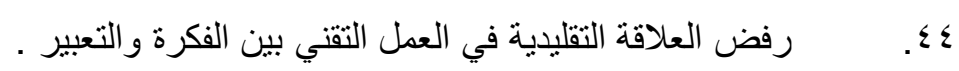

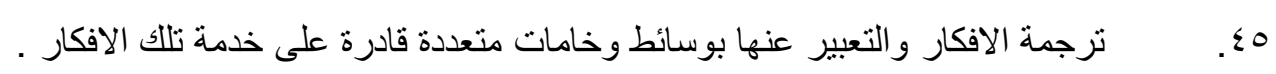

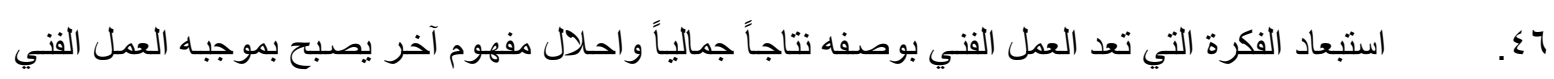
منتج فكري مترجم تشكيلياً.

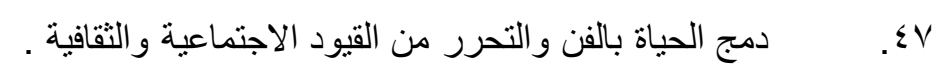

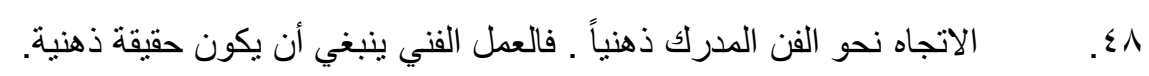

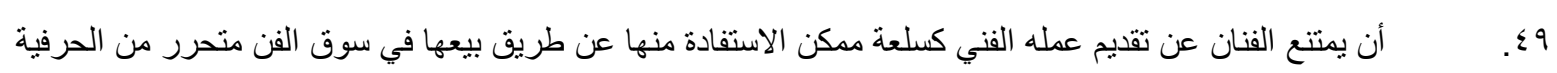
•. . ابراز الواقع كقيمة جمالية والاساس في ذلك هو الفكرة المفهوم . ا ror

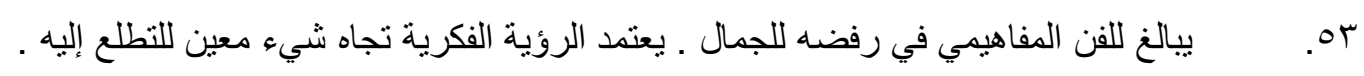

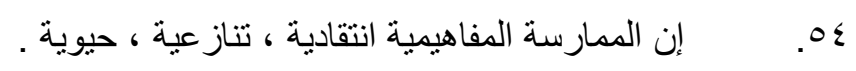

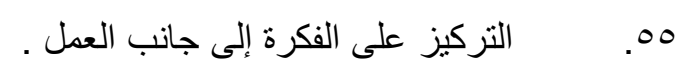

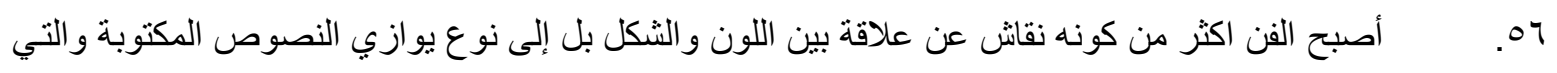
تعد كرسائل حقيقية يوجهها الفنان إلى المتلقي . . ov

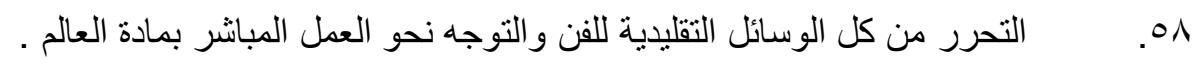

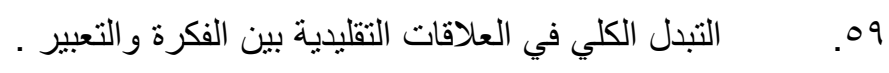

\section{الفمل الثالث- إجراءات البمث}

أوراً : مجتمهر البـهن

يتكون مجتمع البحث الحالي من الاعمال الفنية لفنون مـا بعد الحداثـة وبالتحديد الفن المفاهيمي ومـا

يخص فن اللغة و التي تنـمل (مصور ات ، مواد مختلفة ، صسورة كتابيـة) و المحددة بدر اسـة موضوع البحث الحالي والموجودة على شبكة الانترنيت وقد بلغ عدد مجتمع البحث (ب0) عمل فني . 


\section{ثانباً : عبنـة البـهث}

قامت الباحثة باختيار عينـة بحث بلـغ عددها (0) لوحة فنيـة بصورة قصدية بعد أن صنفتها حسب

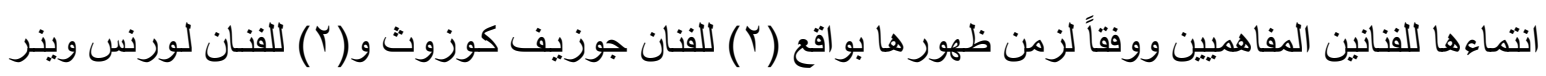
و( ( ) للفنان بالديساري

\section{ثالثناً: أداة البهـث}

أ. لتحقيق هدفا البحث اعتمدت الباحثة على المؤشر اته الفكرية والجمالية والفنية والنقدية ، التي انتهى إليها الإطار النظري في بناء أداة بحثها بصورتها الأولية . ب. بعد أن ثتتت الباحثة استمارة التحليل بصورتها الأولية(*)، قامت بعرضها على على عدد من المتخصصين

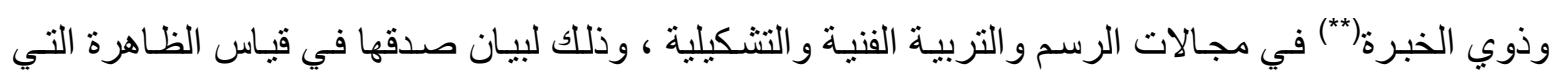
وضعت من اجلها، وقد كانت نسبة اتفاق الخبرات هي (1^v\%) و هذه النسبة تعد مثالية في القياس.

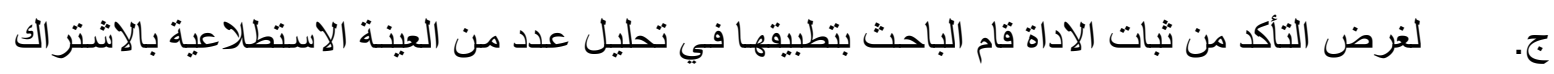

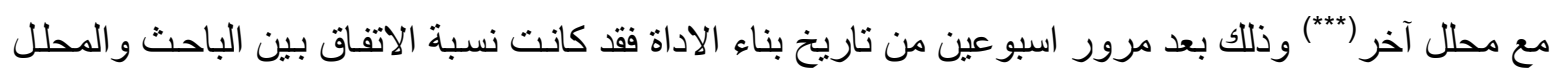
(10\%) ثم اعادت الباحثة تحليل تلك العينة مع محلل ثاني( نسبة الاتفاق بين المحلل الأول والثاني بمقدار (ب^\%\%) و هذا يعد ثباتاً مثالياً للاداة وبذلك تعتمد الباحثة الاداة بصيغتها النهائية(1**** في تحليل عينة البحث. رابـعاً : الوسائل الإهصائية

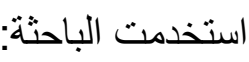

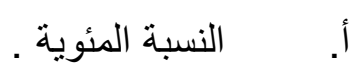
$1 \cdots x$

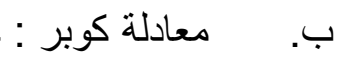

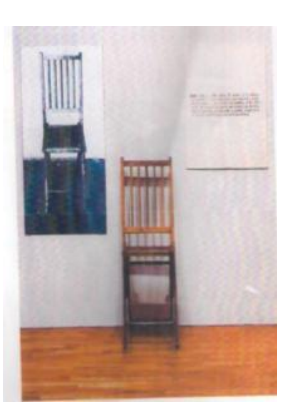

$$
\begin{aligned}
& \text { نسبة الاتفاق } \\
& \text { نسبة الاتفاق + نسبة عدم الاتفاق }
\end{aligned}
$$

يمثل الثكل جزء من نظـام معرفي شـامل يحتوي ثنلاث مر احل لارجاع الثكل (الكرسي) المرحلة الأولى تتمثل بتركيز الانتباه على المعلومة المعجمية (اللغويـة) للكرسي، وهو انتباه انتقائي له دوره في نقل 
المعلومة إلى مستوى اعمق واكثر دلالة ، بفعل ارتباط هذا الانتباه الانتقائي بدافعية ذات مستوى خاص ، لنقل

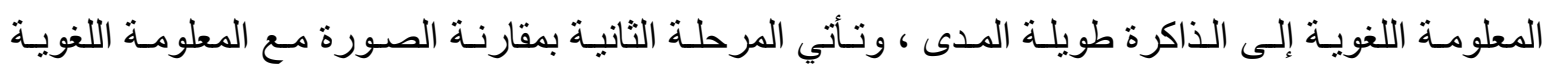
المختزنة ، لتتحول إلى صورة مدركة ، و هنا يتحول الثكل إلى تمثنيل صوري بفعل عملية تعرف ينت بموجبها

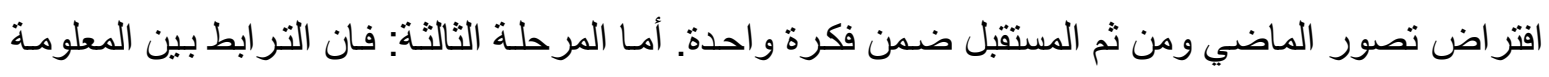

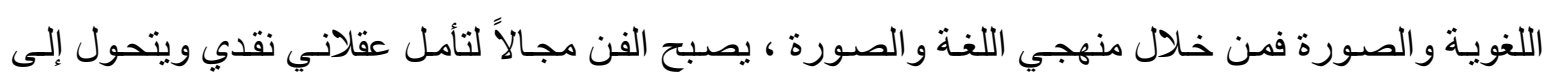
تحليل ايديولوجي على وفق لغته المكتوبة .

من خلال توجه الفنان لشرح كيفية توجهه نحو مناقتشة الفن بمصطلحات نظريـة متعددة وبعدة طرق، منها ما سعى به الفنان للمقابلة بين الأشياء الحقيقية المادية ، وبين تمثيلاتها بالصورة الفوتو غر افية وتحديداتها

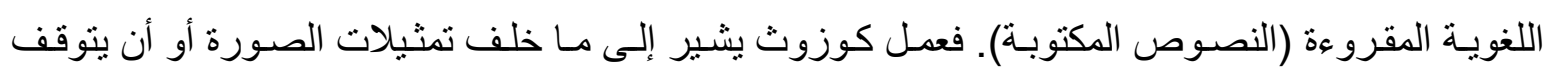
الثيء عن أن يكون ما هو عليه فالأشكال تتطابق مع تفسير اتها وبذللك فالعمل الفني هنـا لا يتو اجد بالتناستق الثكلي للمفردات الموزعة انمـا يتواجد في فكرة العمل نفسه وهنا فان الفنـان يحيل المتلقي إلى شكل ممثل لسيميائه.

إن عملية القر اعة التي تختص بفكرة العمل هي مرحلة مهمة لأن الفنان يقوم بوضعها ضمن سباق الفن البصـري ليتحـول الأخير إلى فن ثقافي فلسـفي علمي ولغوي، فـلا يتبقى من الثـيء الفنـي إلا تحليله

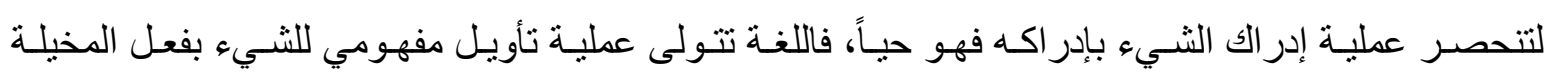

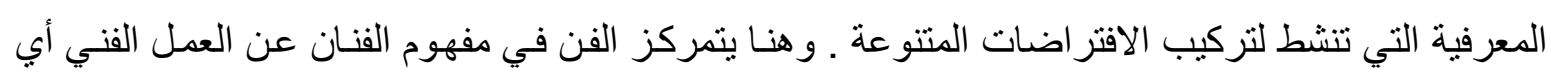
طرح ومناقثة القضايا التشكيلية بالكيفية نفسها التي تعالج بها قضايا فكرية أو علمية أخرى فالمسادة الأولية هنـا

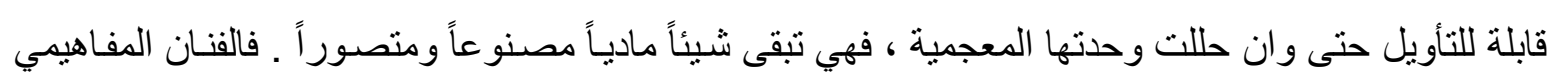
له القدرة على توليد الافكار ونقلها وتوصيلها للجمهور من خلال النقد و التعليق على السياسـة الجماهيريـة، لأن الفن هنـا اصبح حدسياً محتويـاً لكل العمليـات الفكريـة ، ومن جانب آخر لم يعد الفنـان بحاجـة لأي مهارة.

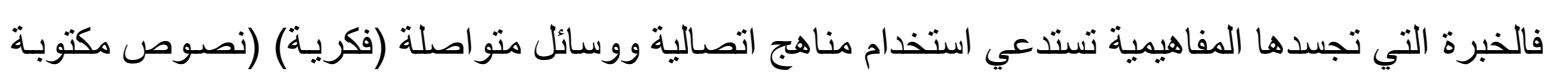

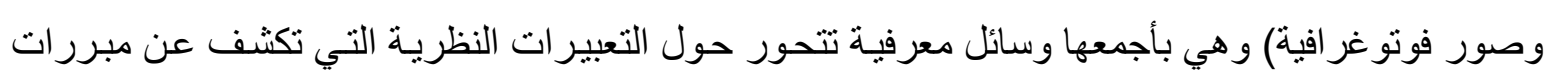

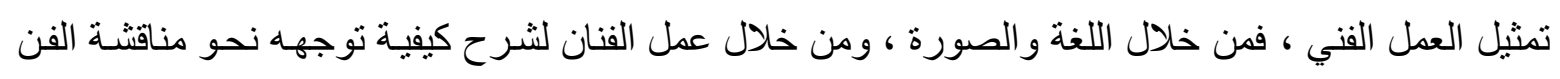
بمصطلحات نظرية متعددة وبعدة طرق.

اعتمد الفنان الالوان الواقعية في تجسيد العمل الفني إذ استخدم اللون البني للكرسي الحقيقي كونهـ في

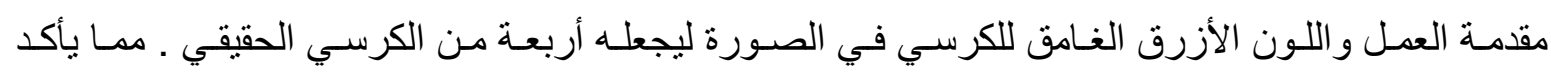
استخدامه للبعد الثالث من خلال اختلاف اللون ضمن فضـاء حقيقي. استخدم الفنان حقول كتابية للغـة مقرو هة لتفسير كلمة كرسي، أي انها ذات مضمون كتابي محدد، ويتسم العمل الفني بأنه لا و اقعي وذو مضدمون عام غير محدد وضمن تقنية غير مألوفـة ، اضـافة إلى غيـاب المعنى المحدد فالعمل الفني اصبح مجـالاً لتأمسل عقلانسي نقدي ويتحول إلى تحليل آيديولوجي على وفق لغته المكتوبـة ، فالفنـان يعمل على تقويض مـا هو 


$$
\text { عينة (r) اسم الفنان : لورنس وينر }
$$

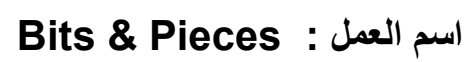

المادة : زيت على قماش القياس : צ www.aetsconnected.org سنة الاتتاج : 19 العائدية : شبكة الاتترنيت

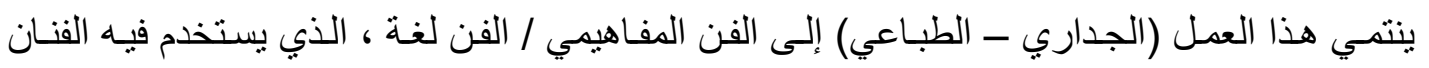

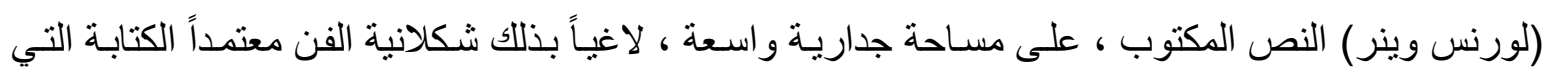
تجعل الكلمة مرئية ، حيث يبتعد التقييم الجمالي و المعرفي عن وظيفة الثكل لأن الفن أساسـاً انتقل من الثكل

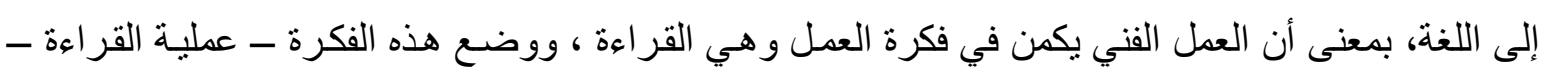
في سياق الفن الصوري ، يعني تحويل الفن البصري إلى فن ثقافي فلسفي علمي لأنـه فن يتموضـع في نقطسة

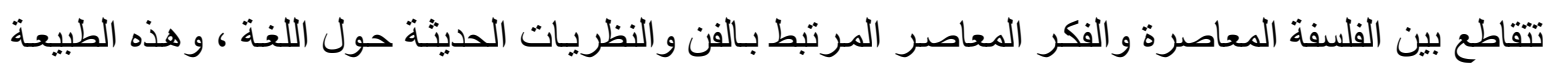

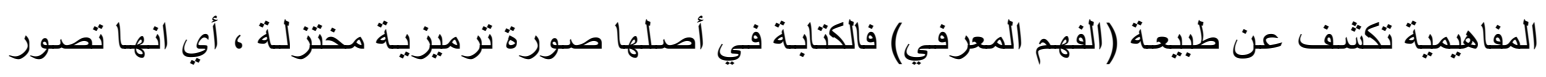
الأفكار عن طريق ائتلاف حروفي، لكن يتم استبدال الصور التي ترمز إلى الأصسوات بـالحروف ويؤكد ذلك مقولة (وينر) : (حين تتعاطى مع اللغة ، فلا احد لما يمكن أن ينتج من تداعي الصور وتشظيها ، انك تتعامل مع كيان مطلعه ، فاللغة - بوصفها اكثر ما طورناه و عكفنا على توسيعه من أنسـاق في عالمنـا ـ هي الأكثر

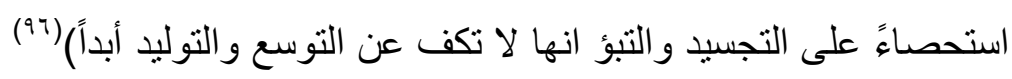
إن ما يقصده (وينر) من قوله أن اللغة لا تكف عن التوسع و التوليد، هو قدرتها على منح العمل معنـاه

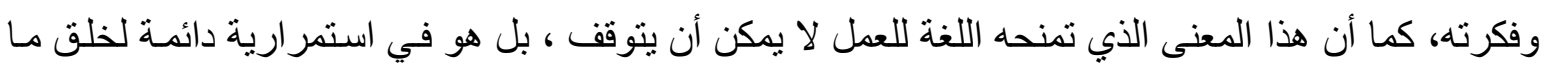

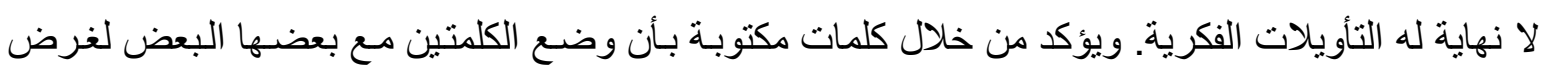

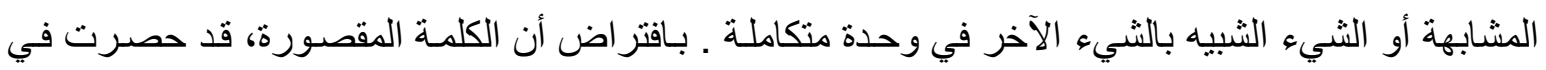
الذهن عقلانياً وكما يقول (ديوي) (إن المعنى المرموز له بكلمة معينة ، كان يمكنه الدخول في علاقات مـع أي

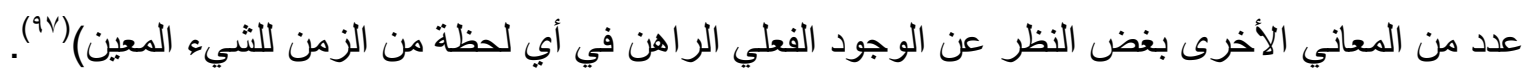
إن مدلول لفظ ما لابد أن يتقابل مع لفظ آخر مر ادفاً له، ويتمثل ذلك في افتر اض أن علاقة (\&) التي تفصل بين كلمتي (Pices , bits) لها قيمة تشاطرية، وينبغي بطبيعة الحال أن تقبل بـالفكرة التي تقول : انـه

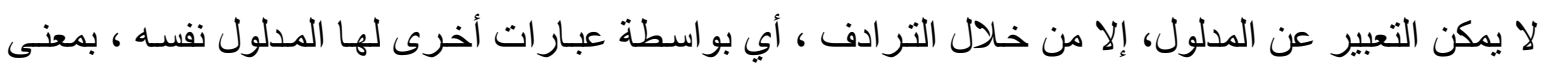
أن خاصية فهم المفهوم تحمل طبيعة دائرية ، تتنقل من كلمة إلى أخرى وكما يقول (امبرتو ايكو) : (بالامكان التعرف على عدة مجمو عات من المعطيات الحسية على انها الثـيء نفسـه ، وتبعاً للذلك بوصفها هامشين

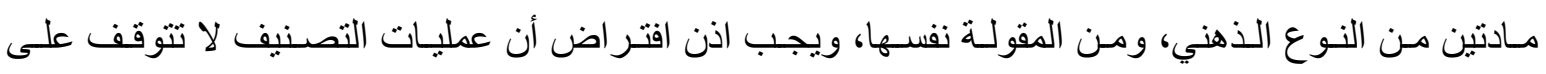

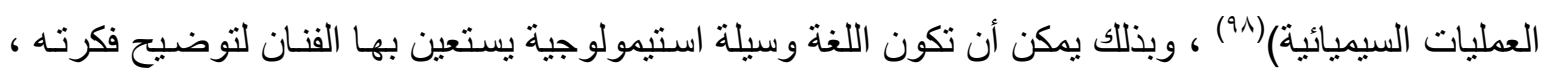
وكذلك المتلقي ـ ويلتقي (وينر) مع (فتجنشتين) الذي ينظر إلى اللغة بوصفها تعبير اً عن نشاطاتتا المتتوعة ، بل هي أداة للفعل و العمل ، (الفصل الأول فلسفة اللغة عن فنجنشتين) ـ وكذلك وينر الذي يشير إلى عملية

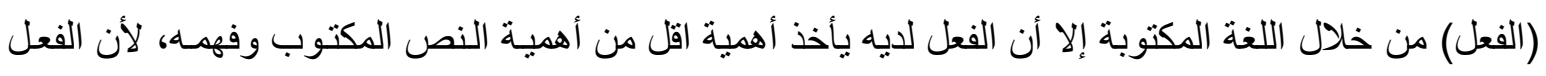

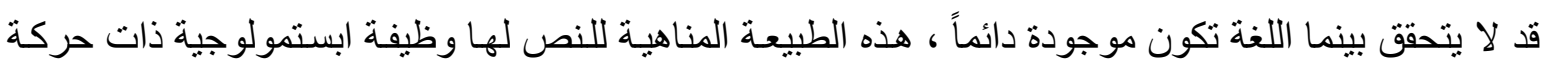


ديالكتيكيـة بين الهرمنيوطيقيا و السيمولوجيا ، فتعمل على تحويـل العلاقـة الحواريـة بين المؤول والنص إلى علاقـة هرمينوطيقيـة للفهـ والادر الك، ومن خـلال دراسـة البنـى السيمولوجية المؤسسـة للنص، سيمحق الفهم

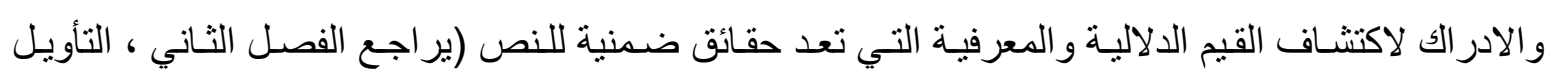

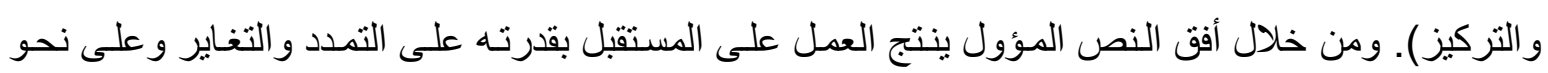
يجعله شكلاً من اشكال التواصل الثقافي ، فالنصوص التي يكنيها (وينر) لا تخلو من بنية ناتجة عن نشـاط ذهني يدرج الكلمات في نظام متر اكب ويجعل من النصوص بمنزلة رسائل دلالية موجهة إلى جموع المتلقين لئل

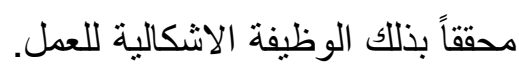

إذ اراد بعض الفنانين توسيع نطاق الفن المفاهيمي بتوجيهه نحو تفسيرات تعتمد اللغـة على نحو كلي

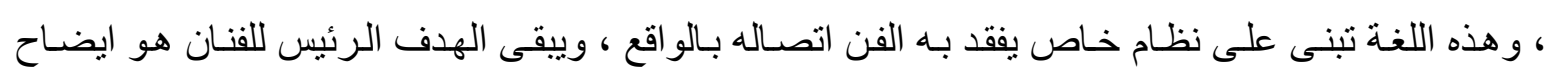
المماتلة بين الكلمات المتشـابهة في تفسير اتها ومعانيها ، و التي تمكن أن تجتمع معاً رغم الاختلافات اللفظية

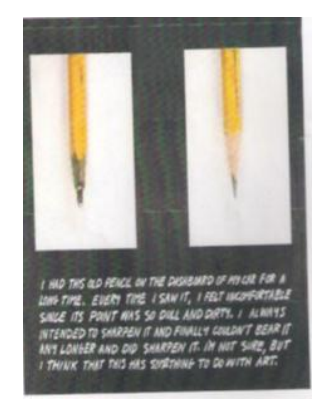

و هذا ما يتبعه (لور انس وينر) .

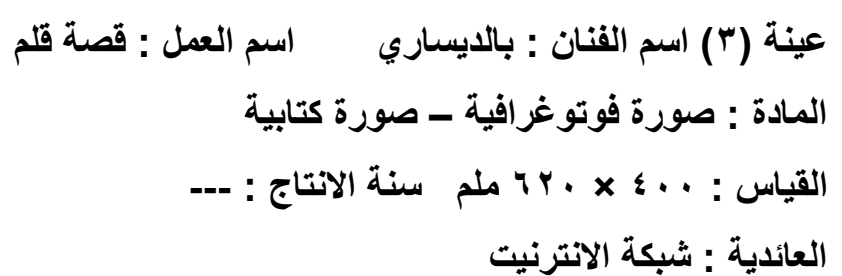

(كان هذا القلم القديم عندي لمدة طويلة في داشيرة السيارة ـ كلما انظر إليه أشعر بالأشياء، لرؤيسة رأسـه غير مدبب ورديء ـ لم استطع تحمل رؤيته هكذا فقمت ببريه لست متأكداً ولكن اعتقد اعتقد إن هذا شيء من الفن) ... تشكل هذه الكلمات الصورة الكتابية التي تعد جزءاً من العمل الفني للفنان و التي يعبر من خلالها عن صورة لقلم قديم من جهة اليسار وصورة لنفس القلم ولكن يوضع أفضل من جهة اليمين وتحت الصورتين

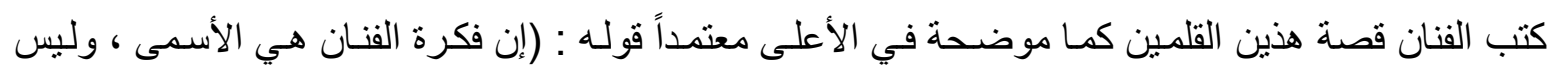

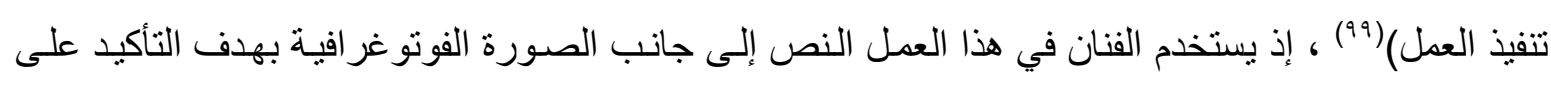
فكرتـه المفاهيميـة ، فالجانب المعرفي و البنائي للعمل ابتعد عن وظيفة الثكل لأن الفن انتقل من الثكل إلى لى اللغة ، وبالتالي إلى عملية القر اءة التي تختص بفكرة العمل ، فمن خـلال منهجية اللغنة والصورة يصبح الفن مجال التأمل عقلاني نقدي ويتحول إلى تحليل ايديولوجي على وفق لغته المكتوبـة ، ويتحول العمل الفني إلى لى فن ثقافي فلسفي ولغوي ذلك لأن الفنان يجسدها ضمن سياق الفن البصري فاللغة تتولى عملية تأويل مفهومي

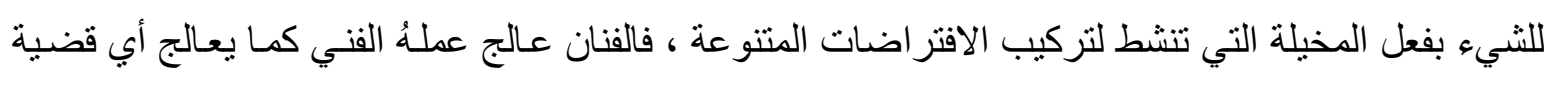
فكرية أو علمية وهي قابلة للتأويل حتى وان حلت وحدتها المعجية فهي تبقى شيئاً مادياً مصنوعاً ومتصوراً ومقسم بسمات دلالية فاللغة هنا لا تتوقف عن التوللد والاستمر ارية في منح العمل معناه وفكرته لخلق مـا لا نهاية من التأويلات الفكرية .

استخدم الفنان مضمون كتابي غير محدد ، قد يكون ارشادات تعريفية لمعنى العمل بشكل عـام إلا أن

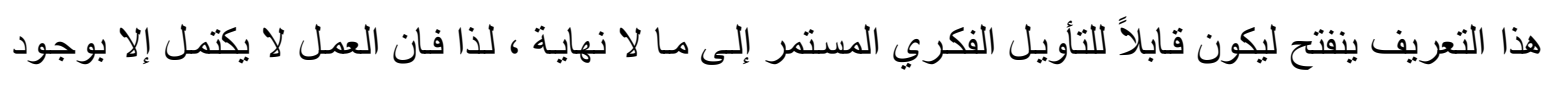


المتلقي لأنها عملية ذهنية ، فينطلق الفنان من اشياء حقيقية وداخل فضاء حقيقي ليمضي بمفهومه إلى ابعد مما تعنيه الصورة واللغة الكتابية المقروءة والثيء المصور يعكس صورة الفكر نفسه وليس نسخة عن الواقع فهو

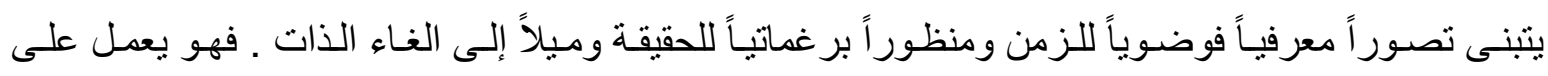
تقويض وتدمير الأنماط السائدة وتقويض العقلانية الغريبة وكل القيم الملازمة لها بوصفها استعار ات مفاهيمية مبينة هذه الطبيعة المفاهيمية تكثف عن صورة ترميزية مختزلة لا و اقعية ولا تشير إلى معنى محدد وهذا مـا

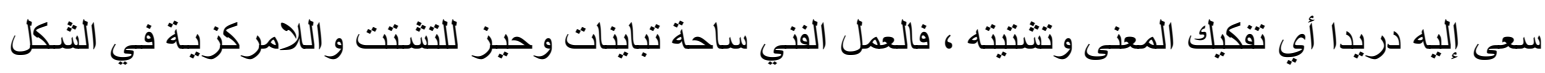
و اللون مع المحافظة على الموازنة في الثكل واللون ، استخدم الفنان التكر ار للشكل كجزء من دن التأكيد على فكرتـه المفاهيمية وكان التكرار على مستوى اللون والثكل ومعنى ايقاع رتيب حقق الفنان في هذا العدل عدمية الثيء حيث انعدام القيم وتلاشي أي معنى للحياة الإنسانية مما ينشئ عنها مضمون غير متجانس. ففي هذا العمل أعلن الفنان رفض العلاقة التقليدية في العمل الفني بين الفكرة والتعبير ، فالفكرة هي

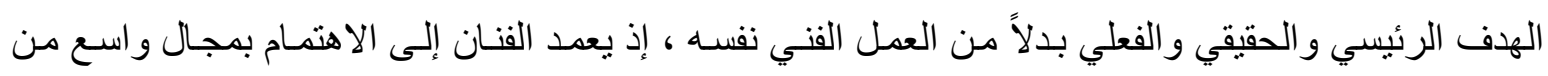

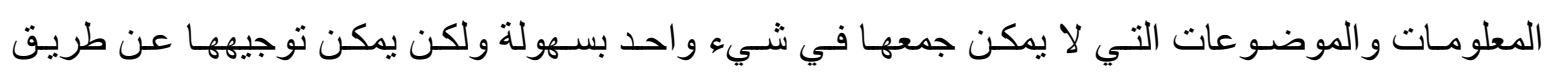
المقترحات المكتوبة والصور الفوتوغر افية باستعمال اللغة وهنا تأكيد على ترسيخ الحالات الذهنية وهو أيضـاً

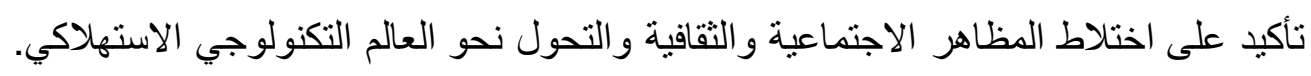
وبالتالي استعاض الفنان عن اللوحة بالأفكار و المعلومـات و المفاهيم فهنالك حريـة في اختيار الخامـات التي تخدم الفكرة أو التي يترجم الفنان من خلالها فكرته باله

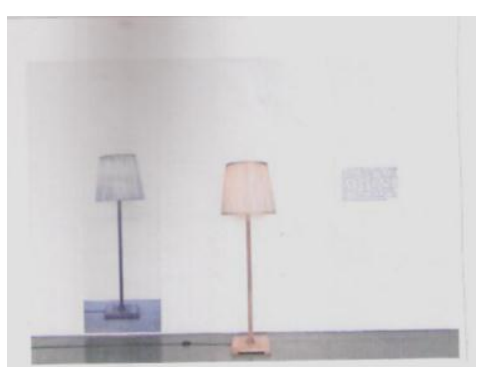

عينة (ई) اسم الفنان : جوزيف كوزوث اسم العمل : واحد وثثلاث مصابيح المادة : مصباح كهربائي صورة فوتوغرافية ، صورة كتابية

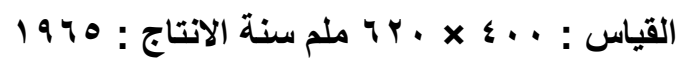
العائدية : شبكة الانترنيت يمثل عمل (كوزوث) واحد وثثلاث مصسابيح بمفردات صناعية منمثلة بالمصباح العمودي المتو هج كهربائياً و المستند على حامل وبـالقرب منهه صورة طبق الأصل من المصباح بدون تو هج ومن ثم التحديد اللغوي لكلمة مصباح كما وردت في القاموس اللغوي إذ يمثل الثكل جزء من نظام معرفي شـامل يحـاول من

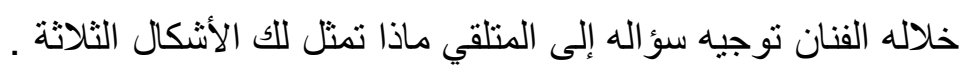
يؤكد الفنان على أهمية نوظيف المفهوم في كسر الإطـار التقليدي للعمل الفني ، بأثر تحول مفهوم الجمال الفني بجمال الفكرة أو التعبير إذ يقوم الفنان على ترجمة فكرته باستخدام أي وسيط ير اه مناسباً للتعبير

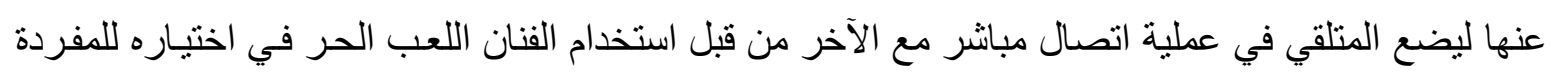
و الخامة المناسبة لتوصيل فكرته إلى المتلقي عبر تفكيك النمط البنائي لمفهوم المفردة المفاهيمية وبنائها لتشكل جدلية مفاهيمية من خلال تعدد القراءات والاستمر ارية في بناء مفاهيم مختلفة تحمل طبيعة القر اعة الذاتية لكل متلقي طبقاً ومفاهيم العصر و البيئة لتحمل الفكرة طبيعة التحول للمفاهيم المعاصرة في وصول فئه المفهوم إلى لى 
المتلقي ـ ومن التقبد بالأسس الفئة التقليدية المألوفة، حتى لو كانت المواد المستخدمة من المهمش و المبتذل ، ذلك ان العمل الفني في فنون ما بعد الحداثة يشتغل بالصفة من السـائد والثابت في اظهار نتاجاته ليجعل من بن

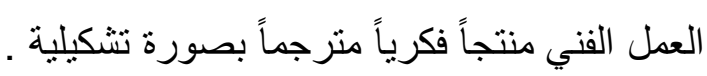

إذ تتحول المعلومة اللغوية في هذا العمل الفني إلى صورة مدركة أو إلى تمثيل صوري وذلك من خلال الترابط بين المعلومة اللغوية والصورة وبذلك يصبح الفن مجالاً لتأمل عقلاني نقدي فالأشكال تتطابق

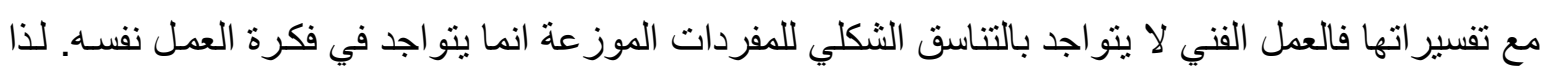

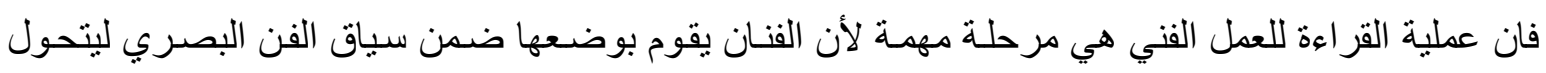

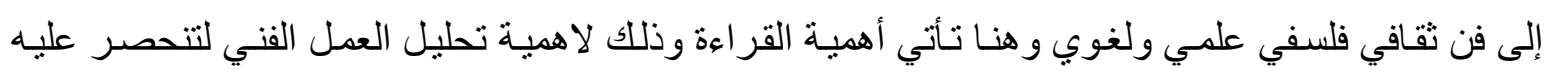
إدر الك الثـيء بإدر اكه مفهومياً فاللغـة تتولى عمليـة تأويل مفهومي للثـيء بفعل المخيلـة المعرفية وهنـا تبرز

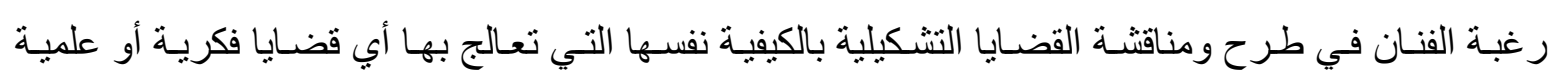

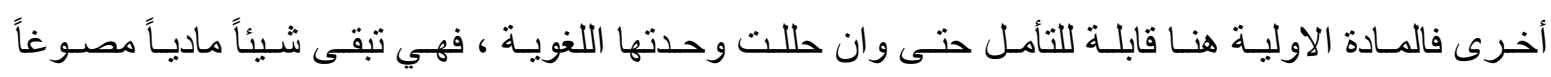
ومتصوراً.

إن عمليـة المصـاهرة بين الفنـون وتـداخلها جـاء مـن خـلال ادخـال الصـور الفوتوغرافيـة إلى العـل

المفاهيمي و ادخال (الكامير ا) في عملية اضفاء صورة المفهوم و ايصالها إلى المتلقي عن طريق توظيف الآلية الصناعية في المفردة المفاهيمية. وبذلك يمتتع الفنان المفاهيمي عن تقديم عمله الفني في اطلار تقليدي بل يعمل على ابراز الو اقع كقيمة جمالية. فالأساس أن العمل الفني هو الفكرة المفهوم دون تجسيد لأي نظريـة، كمـا انهـ

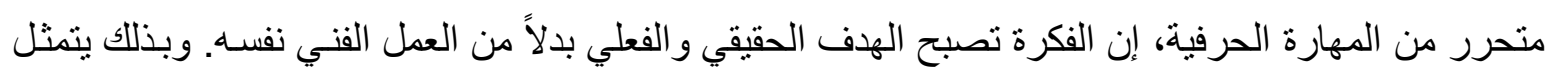

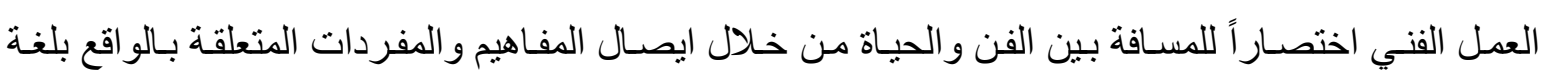
جديدة ، بمعنى التوجهه نحو العمل الو اقعي بشكل مباشر، وهذا النوع من الفن حدسي يتضمن كل العمليات الفكرية وليس لله هدف فالفكرة هي الهدف الحقيقي للفن ، فالو اقع هنـا هو المجال الاساسي لادر الك الجمالي ادر اكاً فنياً ومفاهيمياً جديداً ومدلول الفن المفاهيمي هو التبدل الكلي في العلاقات التقليديـة في العمل الفني بين الفكرة والتعبير ... بالإضافة إلى إن الفن المفاهيمي (فن اللغة) عند كوزوث لم يحاول ايصـال مفاهيم تاريخيـة أي مفاهيم ترتبط بالماضي و التاريخ في تمثلاث المفهوم.
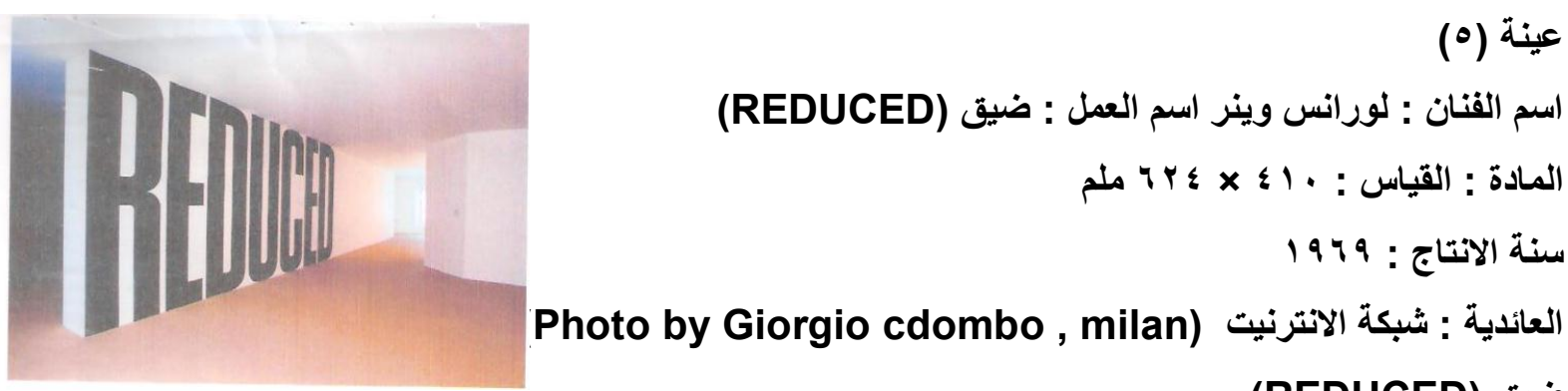
ضيق (REDUCED)

شكلت كلمة ضيق الصورة الكتابية التي شغلت حيزًا كبيراً من العمل (الجداري ـ الطباعي) والذي

جسده الفنان باستخدام العمق أو البعد الثالث من خلال ممر يتسع في بدايته ليضيق في نهاية الممر وصولاً إلى لى منطقة مضيئة لوجود نافذة في وسط اللوحة ويوجد إلى الخلف من الجدار منطقة مظلمـة والى اليمين ممر 
ينتهي باتجـاه العمق بنافذة مضـيئة وكأن الفنـان ار اد التعبير عن كلمـة ضيق كلغـة كتابيـة مـن خـلال ربطها بصورة الجدار الذي يضيق كلما اتجهـ نحو العمق لاغياً بذللك شكلانية الفن معتمداً الكتابة التي تجعل الكلمـة

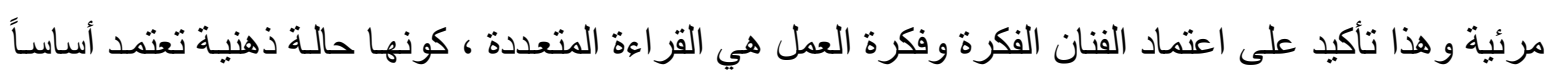
على المتلقي لذا فهي لا تكتفي عند قراءة واحدة إذ تتسم بالتولد و الاستمر ارية بقول وينر (فاللغة - بوصفها اكثر ما طورناه وعكفنا على توسيعه من انساق في عالمنا - هي الاكثر استقصساء على التجسيد والنشوء انها

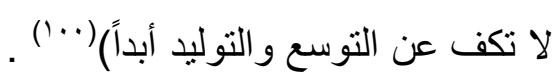

إن النظام التجريبي لـ(فن - لغة) لا يمكن أن يقوم على تفسيرات قبلية أو مينافيزيقية لتحليل المعنى

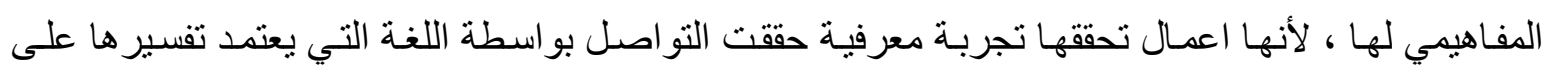

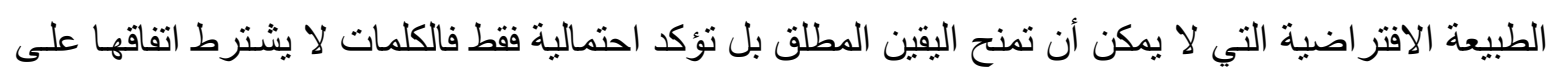

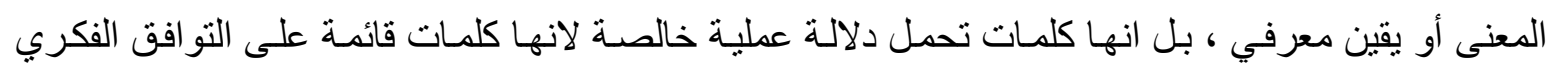
وليس على الترابط اللغوية.

فـالمفردة المفاهيميـة تجعل مـن العمل الفنـي نتاجـاً فكريـاً مترجماً بصـورة تشكيلية ، مؤكداً على أن

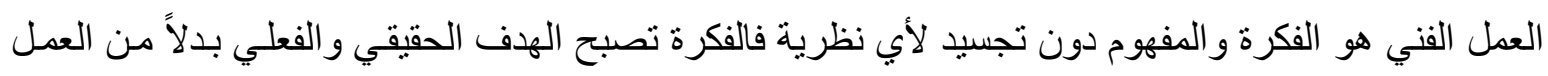
الفني نفسه الذي بدأ مع خطاب ما بعد الحداثة يثتخل الضد من السـائد والثابت في إظهار نتاجاته، ويعبر عن المفهوم المتغير و الآني و الزائل في تمثنات واشتغالات فنيـة. أصبح للمتلقي فيها الدور الرئيسي في قر اعتها مما جعلها متعددة القراءات ، إذ ينطلق الفنـان بحريـة تامـة في عملية اختياره المفردة واستخدامها في ايصـال مفهوم من قبل الفنان إلى المتلقي عن طريق تفكيك النمط البنائي لمفهوم المفردة وبناءها لتشكل جدليـة مفاهيمية من خلال تعدد القراءات في بناء مفاهيم مختلفة تحمل طبيعة القراءة الذاتية لكل متلقي طبقاً ومفاهيم العصر البيئية لتحمل الفكرة طبيعة التحول للمفاهيم.

استخدم الفنان التطور التقني والتكنولوجي غير المحدود على أسـاس أن الفن الحديث و المعاصر لابد أن يكون متصلاً بالو اقع إذ يتحول الفن البصري مع المفاهيمية إلى فن ثقافي فلسفي علمي ولغوي فاللغة تتولى عملية تأويل مفهومي للثـيء بفعل المخيلة المعرفيـة التي تنشط لتركيب الافتر اضـات المتنوعـة. فالعمل الفني عبـارة عن سـاحة تباينـات فهو مجـال للتوتر و التعـارض وحيز للتشتت ، فـالقر اءة هي تفكلك البنى و انفجـار المعنى وتثفي الهوية إضافة إلى تفكيك المركز فلا يوجد مركز ثابت. ولكي يبرز الفنان الو اقع كقيمة جمالية مركزاً على الفكرة المفهوم استخدام الألوان الواقعيـة وذلك من

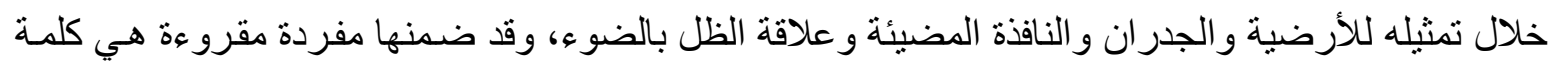

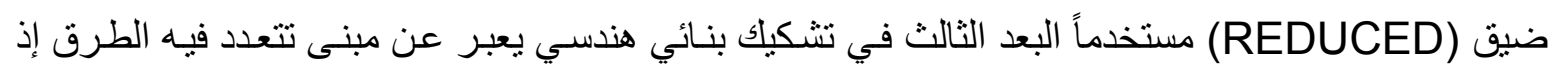
جسد الفنان العمل ككل بشكل غير منطقي وغير واقعي . عبر تقنية غير مألوفة و علاقات مختلفة إذ استخدم عندي

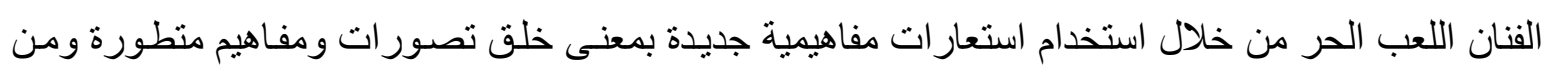
خلال الفعل التلقائي (العفوي) في بنائية الصورة و المغايرة في مشـهدية الصورة الكتابيـة. وبالتالي التأكيد على هلى الفكرة - المفهوم للعمل الفني و غياب الأهداف الكبرى. 


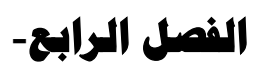

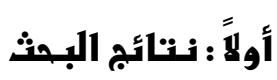

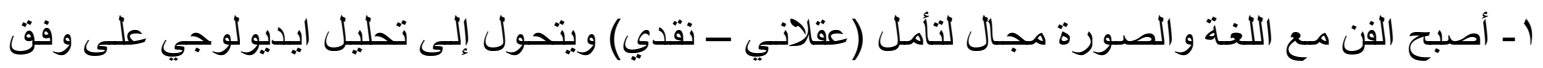

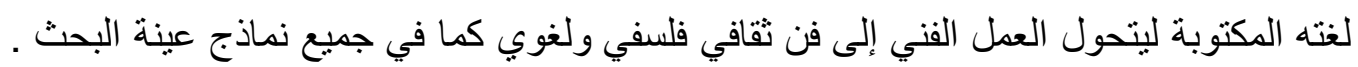

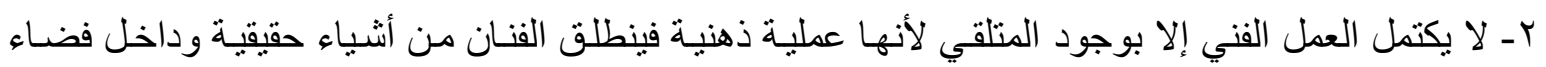

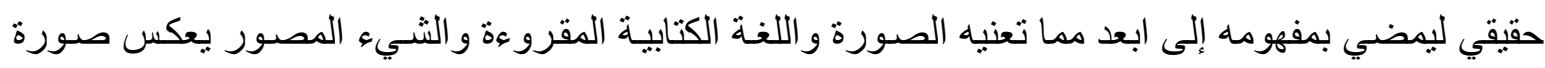

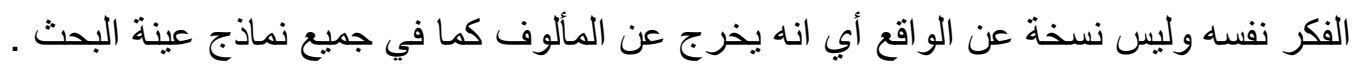

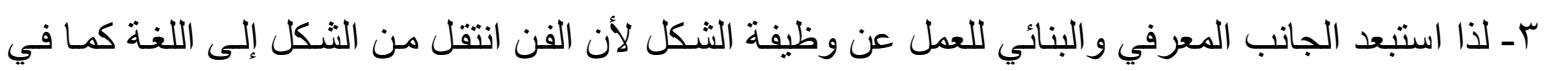
جميع نماذج عينة البحث . ــ اعتمد الفنان المفاهيمي وبتأثير الابعاد المعرفية على الفكرة وفكرة العمل هي القراءة المتعددة كونها حالة

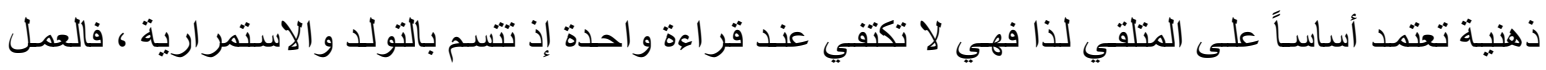
الفني هنا لا يتو اجد بالتناسق الثكلي للمفردات الموزعة انما يتو اجد في فكرة العمل نفسه ، لذا فالمنتلقي شكل

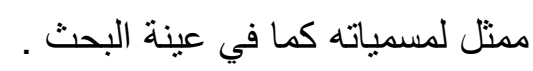
هـ يعتد العمل المفاهيمي على تجربة معرفية حققت التواصل بواسطة اللغة التي يعتمد تفسير ها على الطبيعة الافتراضية الني لا يمكن أن تمنح المعنى اليقين المطلق بل تؤكد احتماليته فقط بالكلمات وهذا ما يؤكد غياب

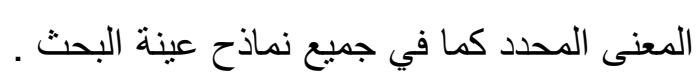

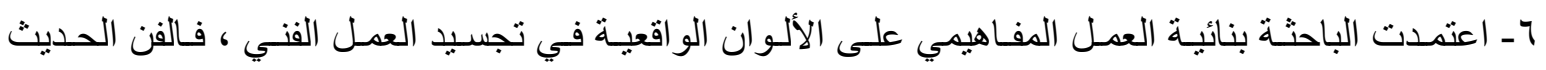

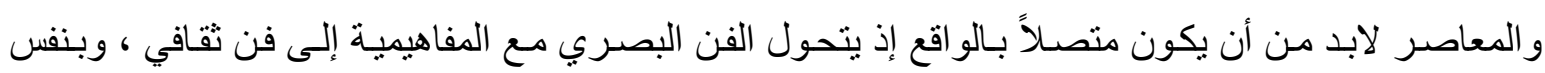

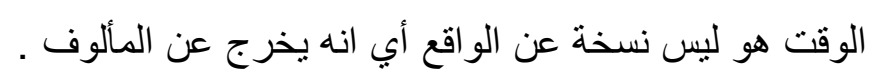

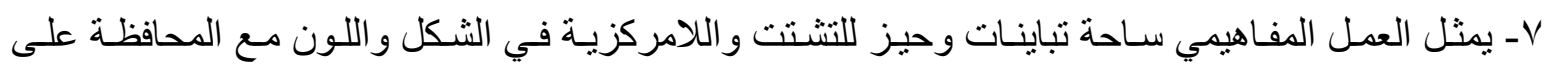

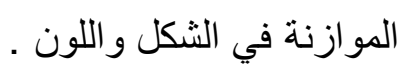

^ـ انتقاء المعلومة اللغوية الذي لـه دوره في نقل المعلومة إلى مستوى اعمق واكثر دلالة بفعل ارتباط هذا

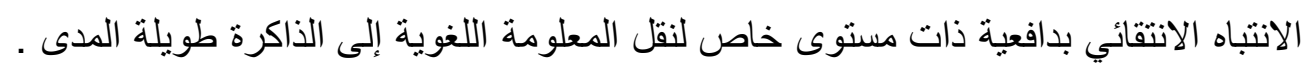

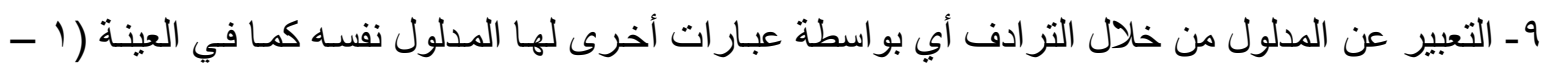

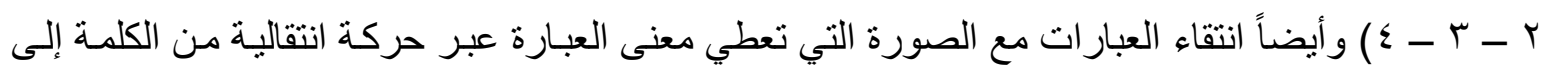

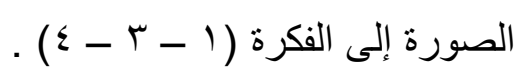

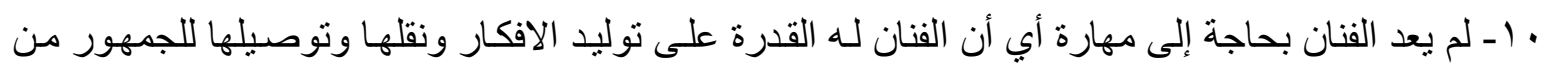

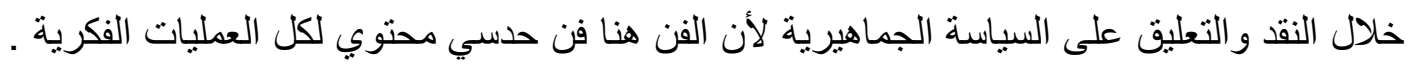

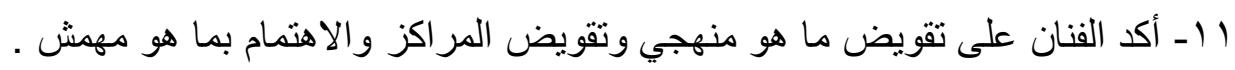




\section{ثانياً : استنــناجات البهث}

ا - وضـوح الـدور الفاعل للمنـاهج النقديـة الحديثة (البنيويـة ، التفكيكيـة ، و السيميائية) في زخرفـة الانسـاق التقليدية لبنية الرسم الحديث واستبدالها ببنى معرفية وبنائية اعتمدت الجانب الذهني و الصوري للتأكيد على صورة الفكر نفسه . ז- إن الاستمر ارية في توليد المعنى وتفعيل المر اكز المهمشـة واعادة قر اعتها في رسوم مـا بعد الحداثـة اثر

بشكل كبير في بنية الفكر ما بعد الحداثي وانعكس فيما بعد على الثكل والتعبير و الوظيفة والقيمة الجمالية .

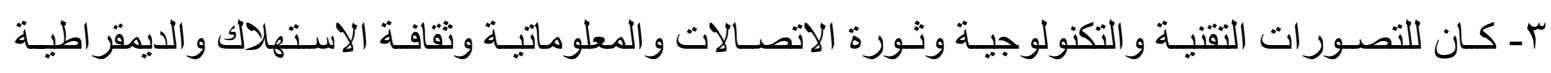
و التحرر الاجتماعي و العولمة اثز كبير ، مما انعكس على بيئة الرسم معرفياً وبنائياً انطوت على ونى بنى ذهنية وصورية انعكست في بنائية العمل من خلال التأكيد على صورة الفكر نفسه .

ثنالثاً: التوصيات

ا - ضرورة إضافة مادة (فنون مـا بعد الحداثة) إلى جميع منـاهج أقسام كلية الفنون الجميلة الفنون التشكيلية وقسم التصميم وقسم التربية الفنية والمسرح للأهمية الكبيرة التي تكنها هذه المسادة في دراسـة مرحلة النصف الثاني من القرن العشرين (تاريخاً ، وفلسفياً ، وفنياً) من حيث التيار وات الفلسفية ومقوماتها ومرجعياتها واهم الاسس التي استندت عليها واسباب ظهور ها . ז- ضرورة التشجيع لنشر الكتب و الصحف و المجلات (الفنيـة ، والأدبيـة ، و الثقافية) و المسـاهمة في ترجمة

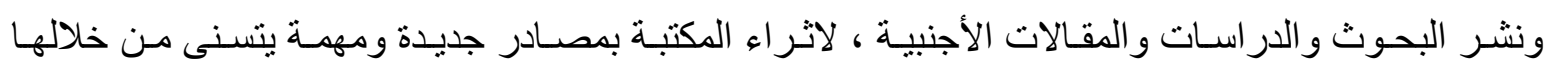
الطالب والباحث و المتذوف الاطلاع على مصادر اكثر اثراءاً .

\section{رابـعاً: : المقتنر هات}

ا ـ الابعاد المعرفية والبنائية بين الفن التعبيري والفن الكرافيتي .

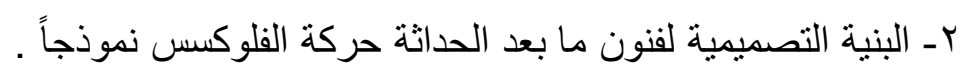

الهواهش

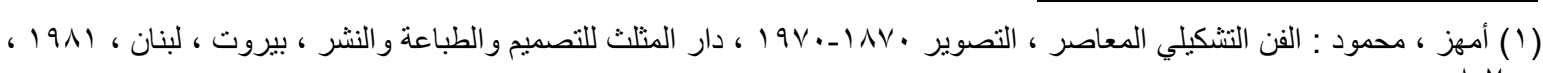
. A-V صن (1)

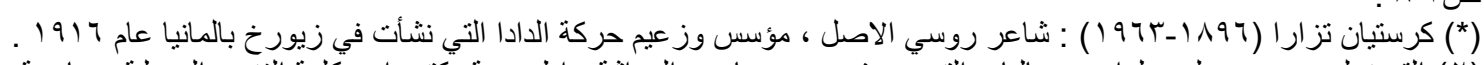

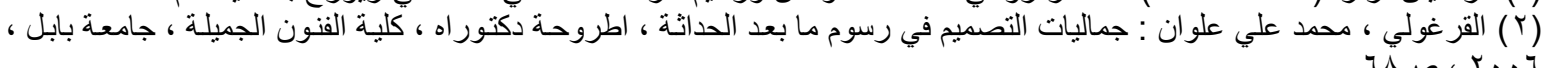

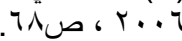

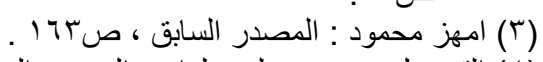

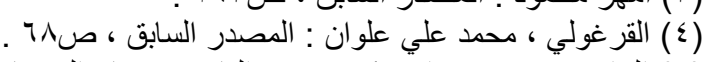

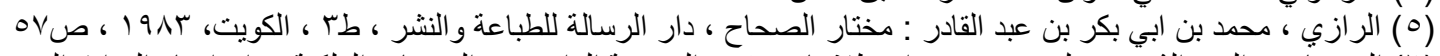

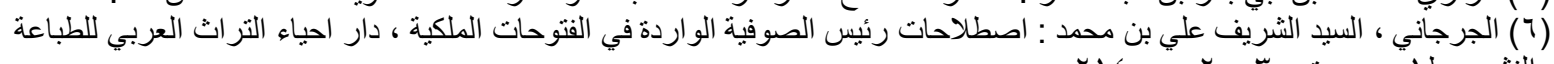

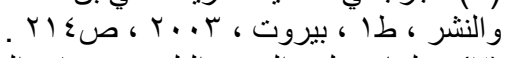

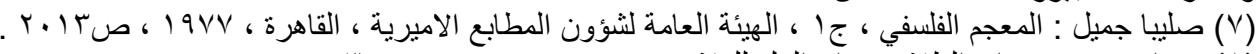

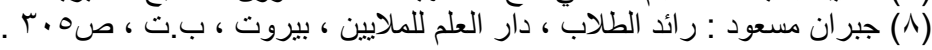

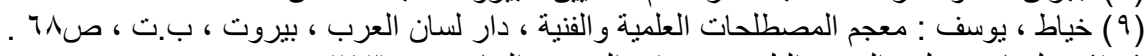

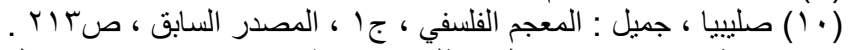

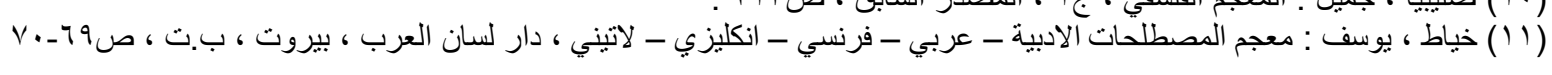

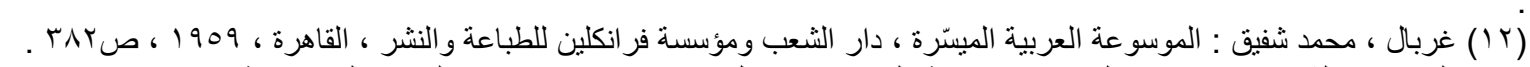

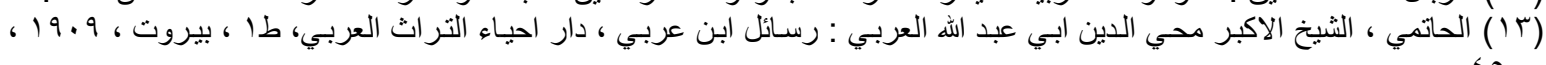




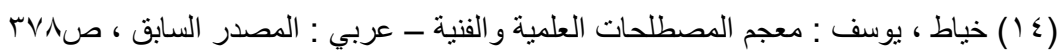

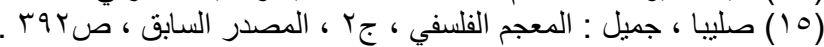

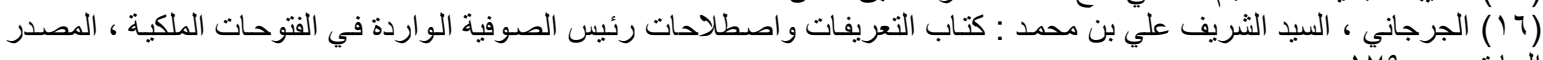

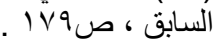

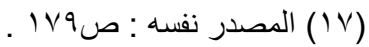

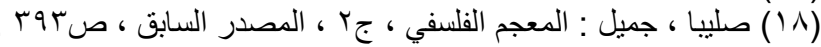

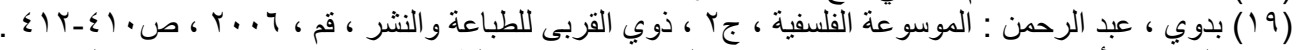

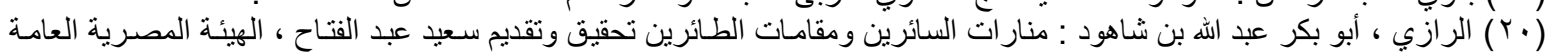

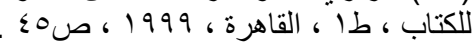

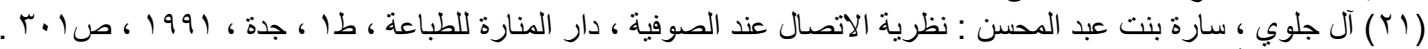

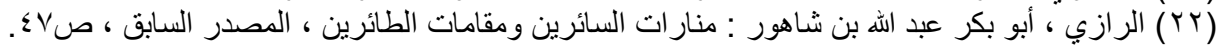

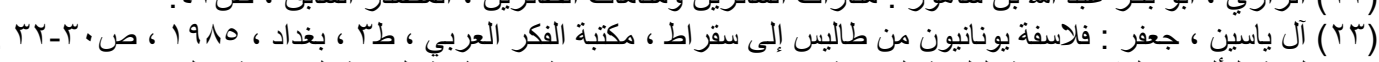

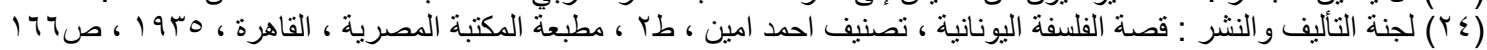

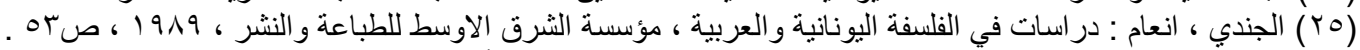

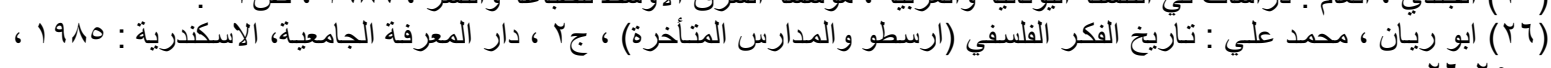
صOr-ry

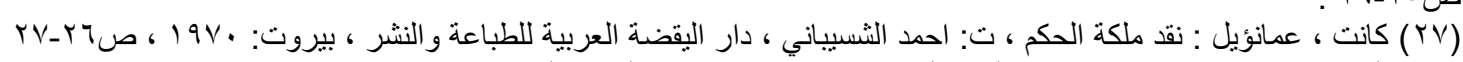

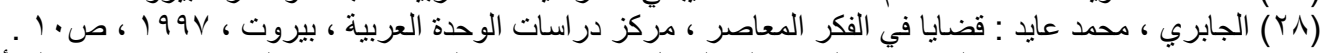

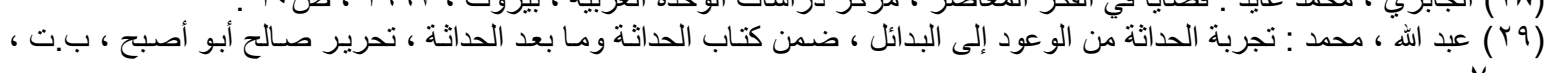

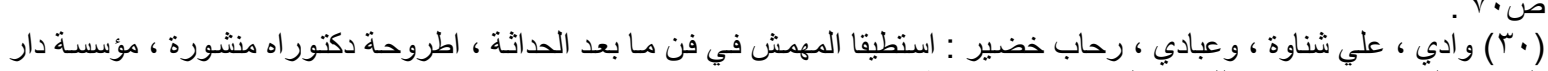

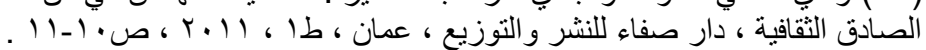

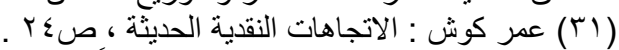

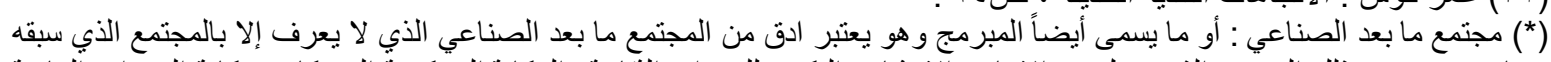

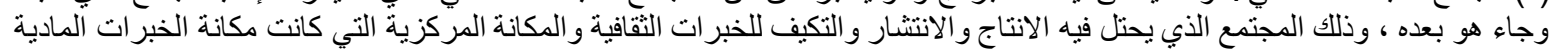

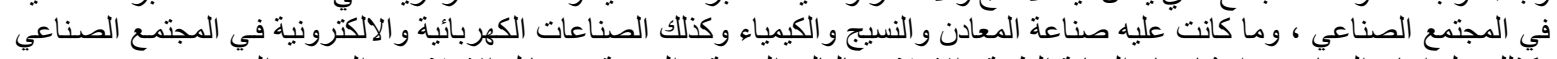

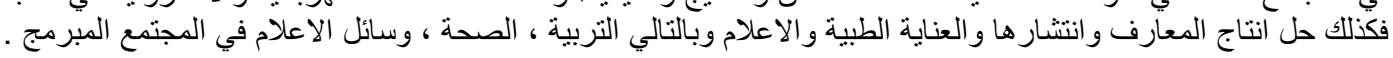

(1) Rudaityte , Regina : Postmodernism and a hater, Cambridg Scholars Publishing , 2008 , P.30

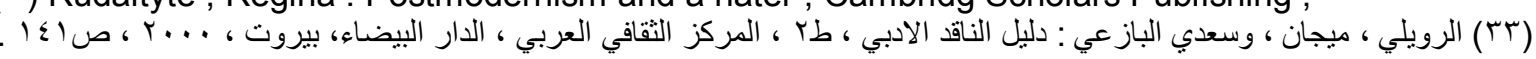

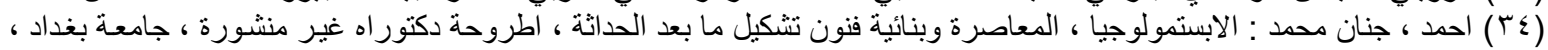

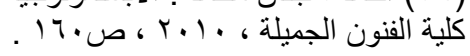

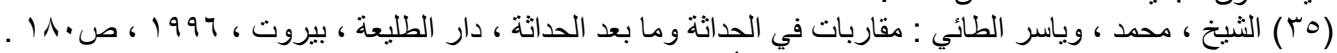

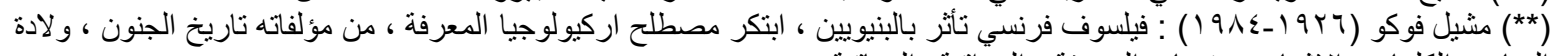

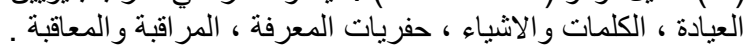

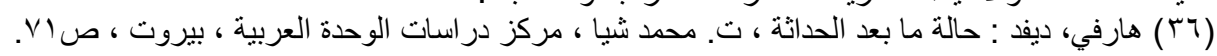

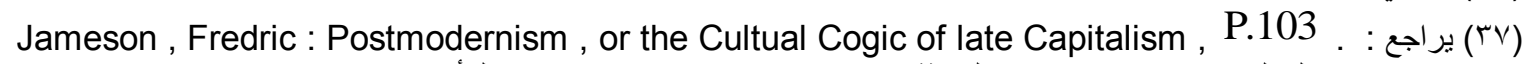

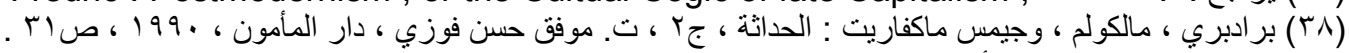

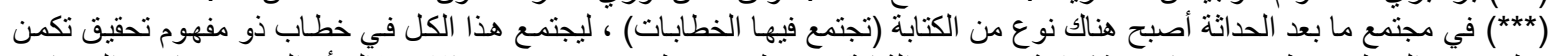

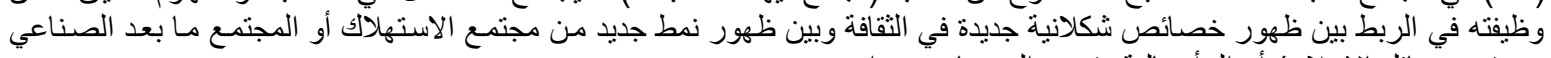

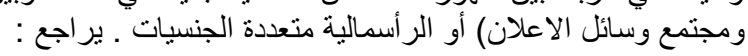

Jameson, Fredric : Postmodernism , or the Cultual Cogic of late Capitalism , P.103

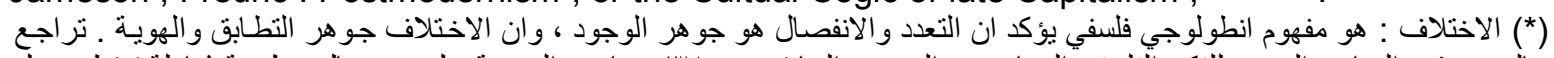

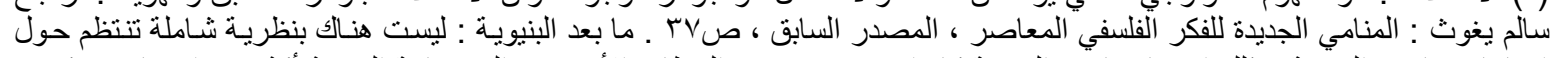

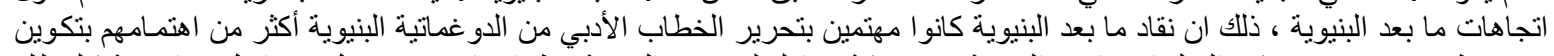

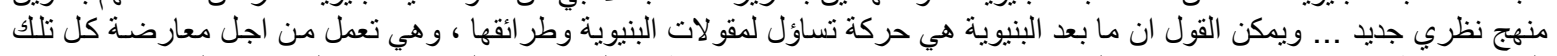

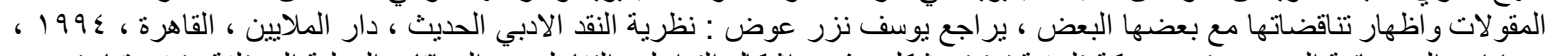

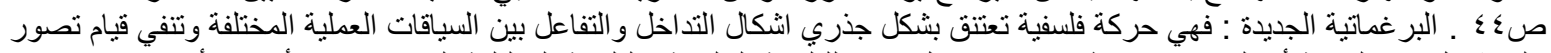

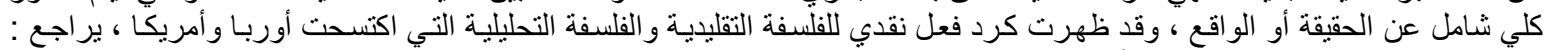

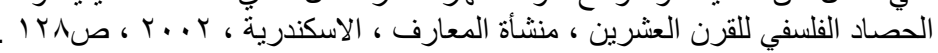

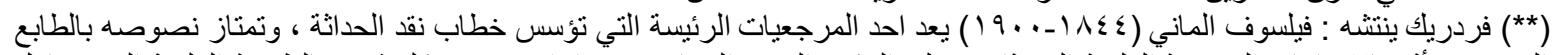

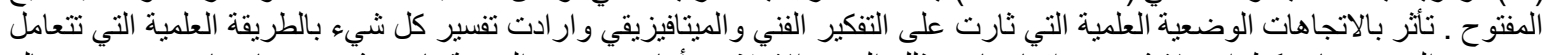

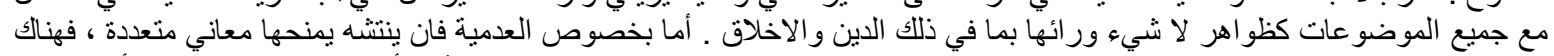

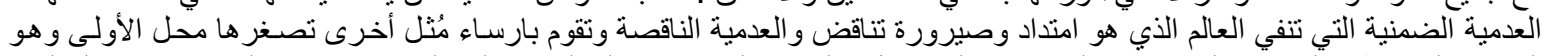

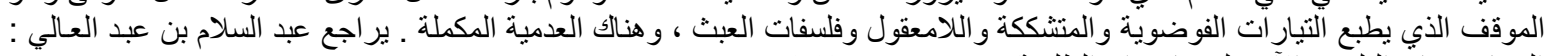

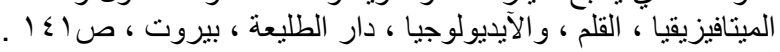

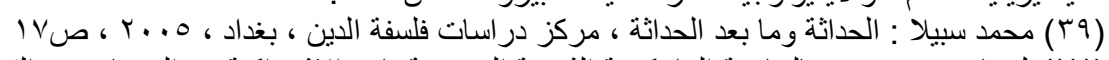

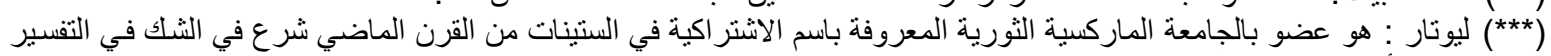

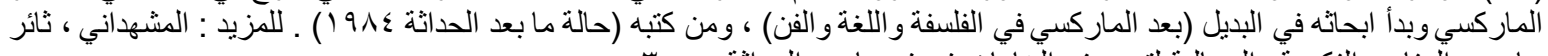

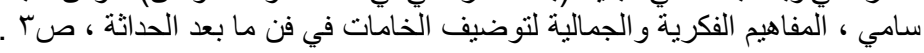




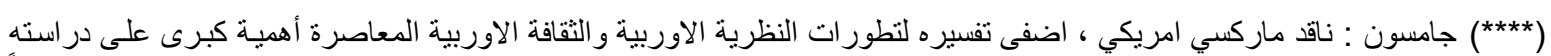

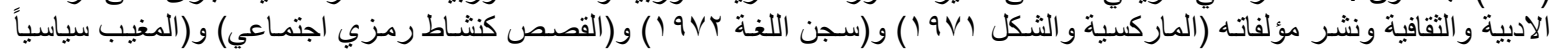

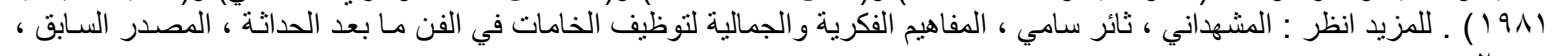
ص.

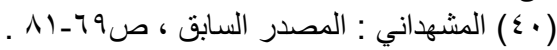

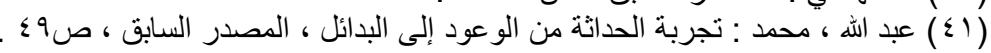
(

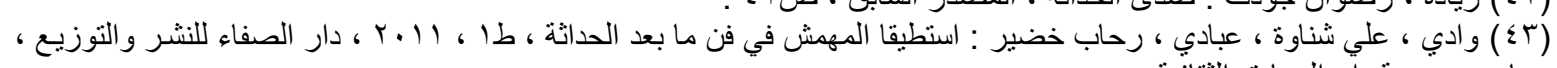

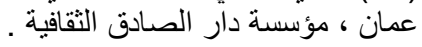

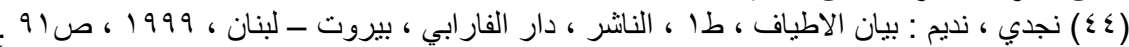

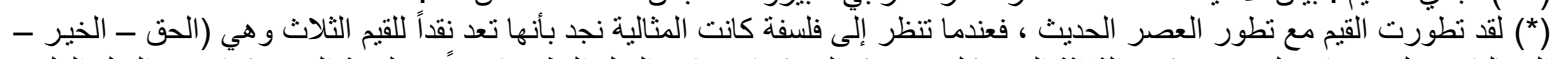

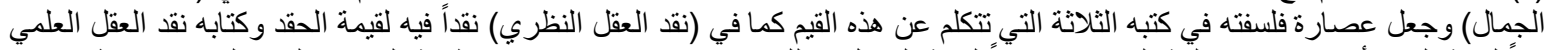

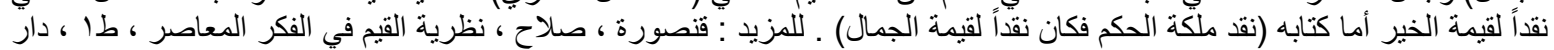

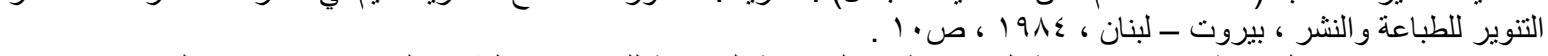

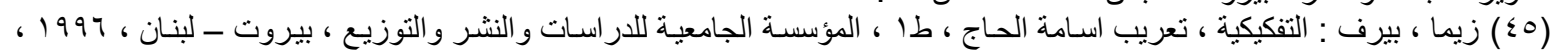
صو

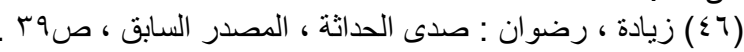

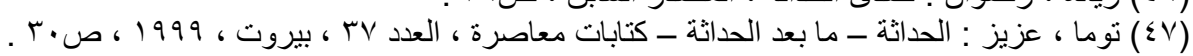

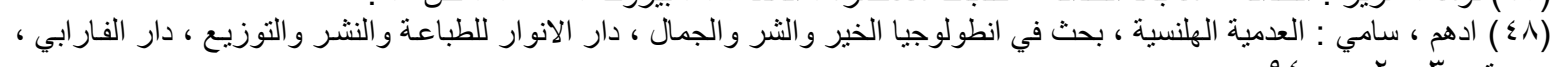

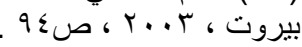

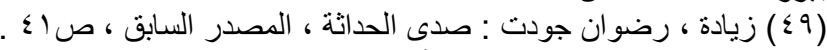

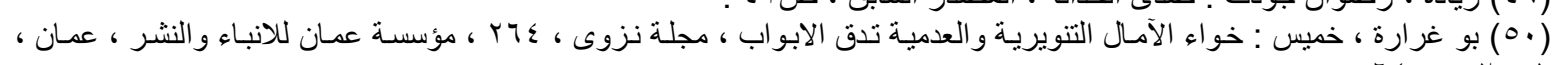

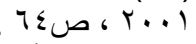

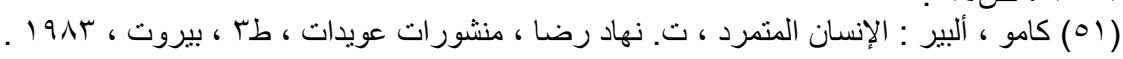
(9 ) RJ. Routledge Holingdale , The man and His Philosophy , Nitzsche , London , 1965, P.120 نقلاً عن آل وادي ، علي شُناوة ، الحسيني ، عامر عبد الرضا : التعبير البيئي في فن مـا بعد الحداثة ، طا ، دار الصفاء للنشر والتوزيع ،

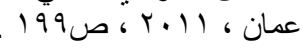

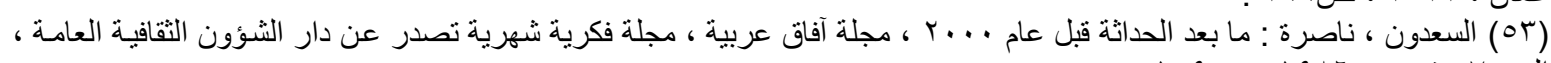

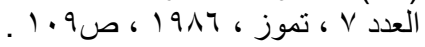

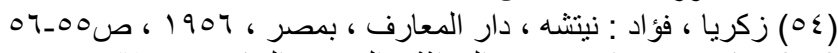

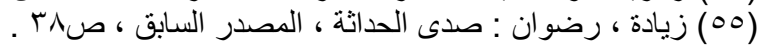

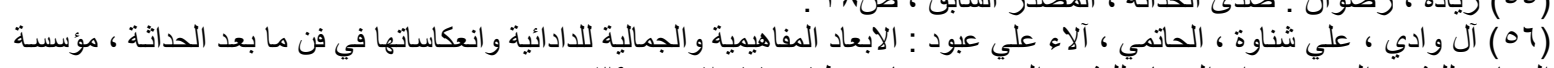

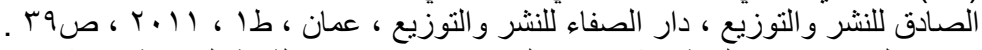

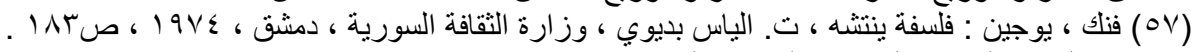
(ON)

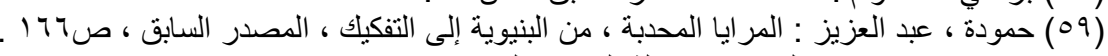

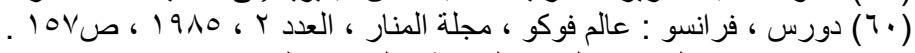

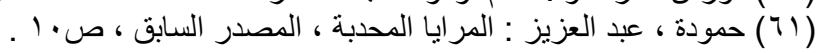

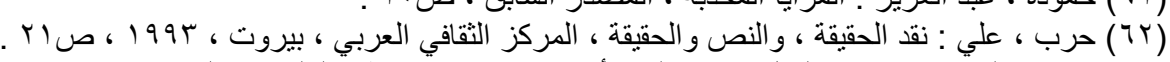

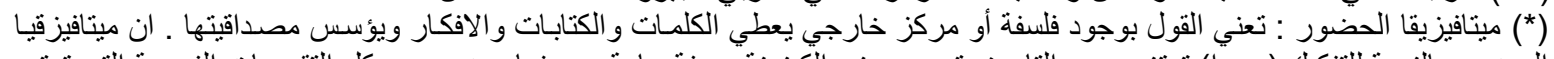

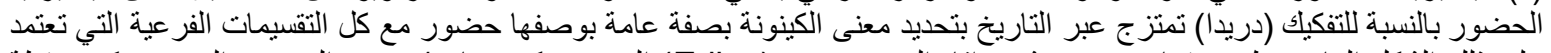

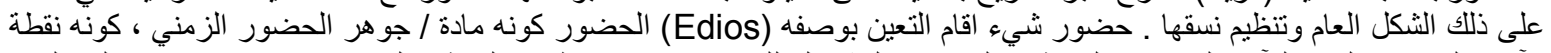

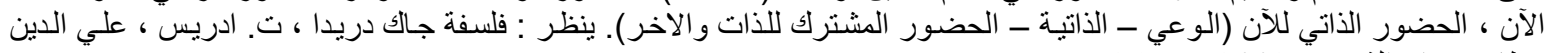

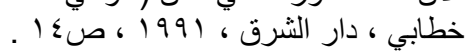

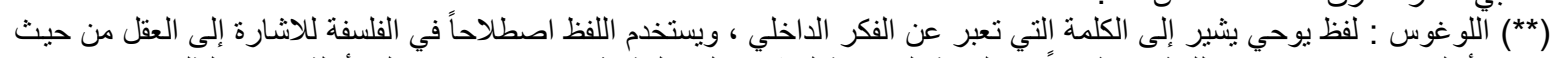

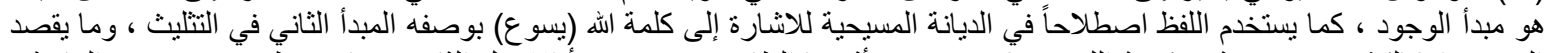

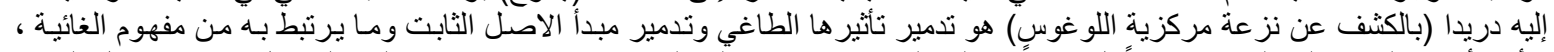

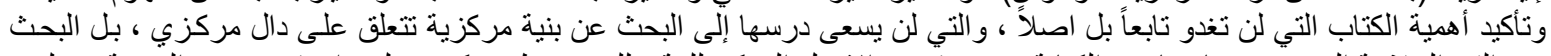

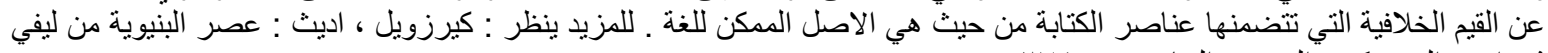

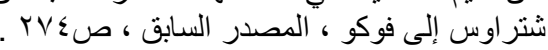

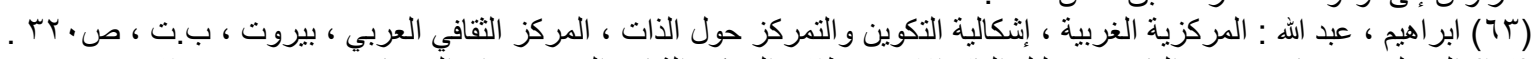

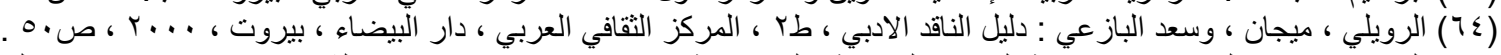

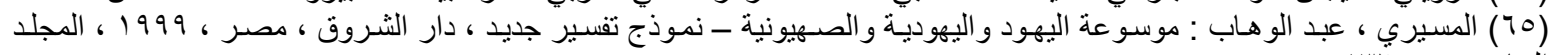

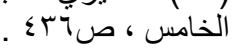

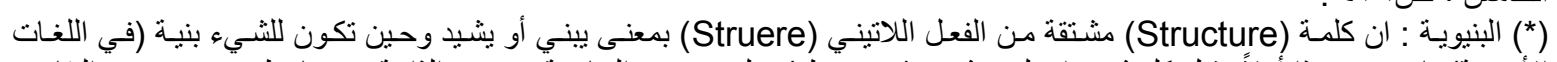

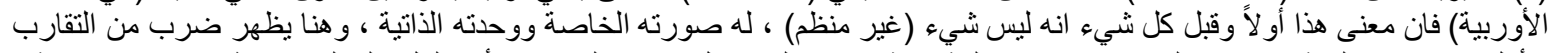

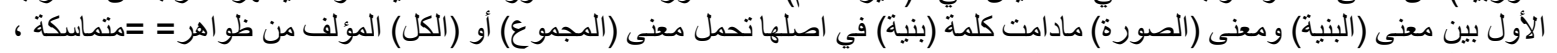

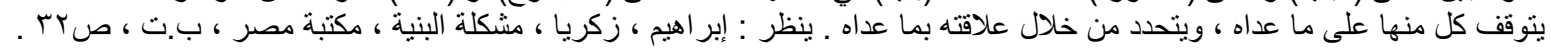




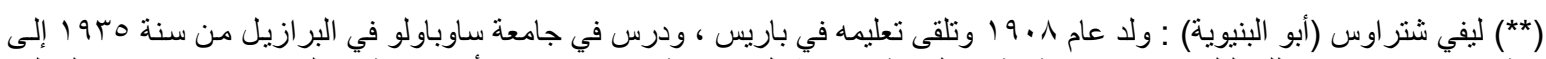

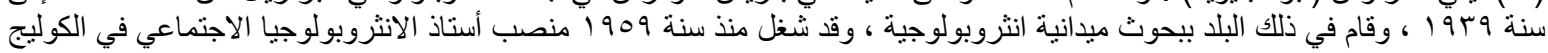
دي فر انس

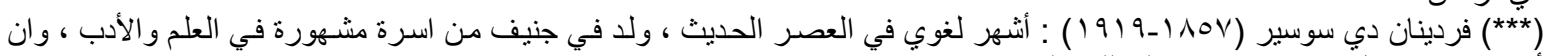

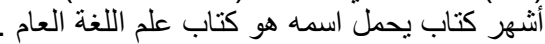

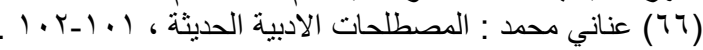

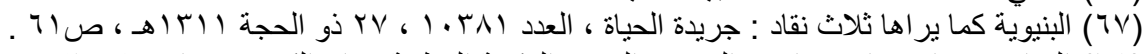

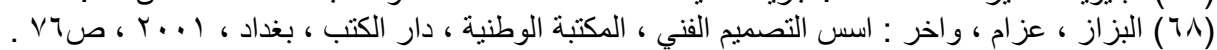

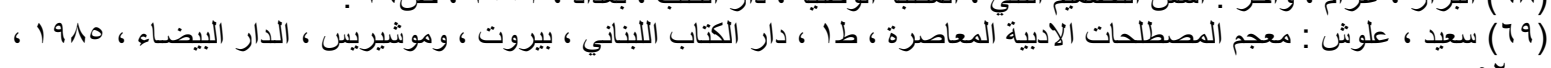

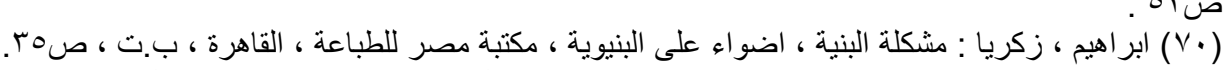

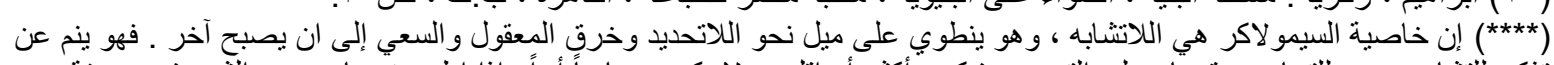

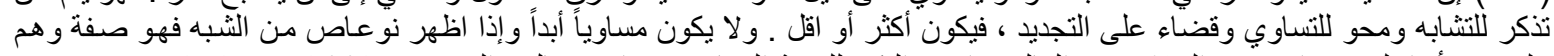

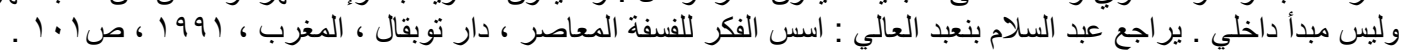

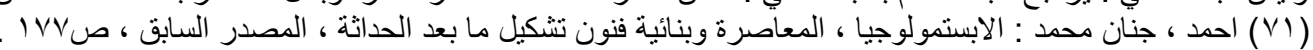

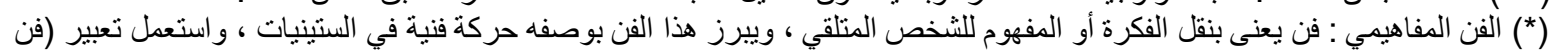

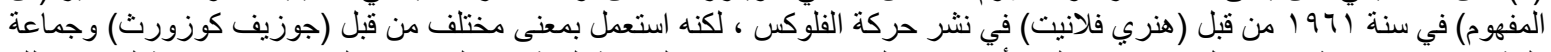

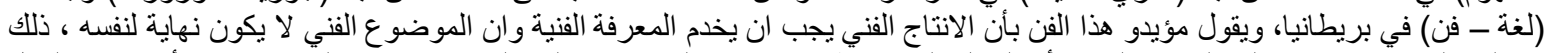

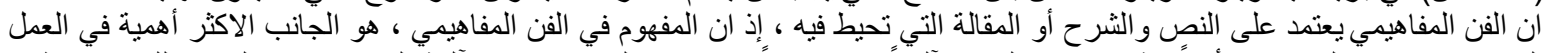

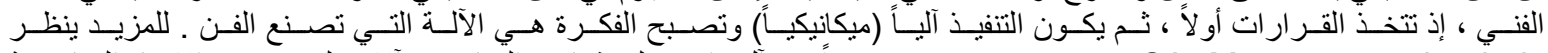
وww.artex.comCArtMovementandperiods

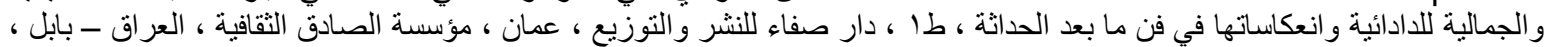

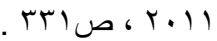

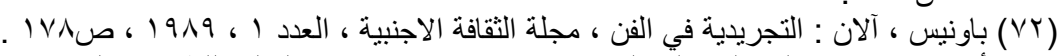

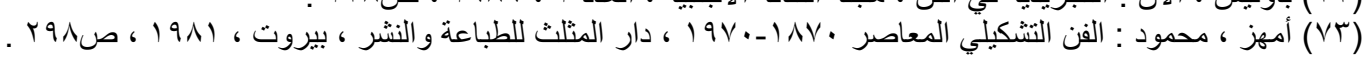

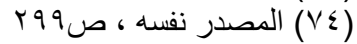

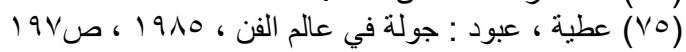

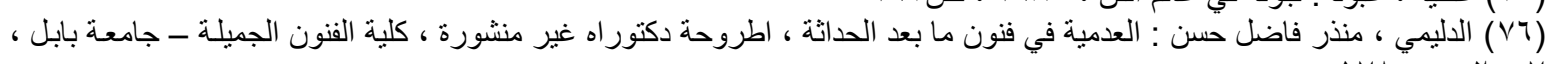

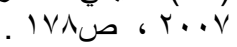

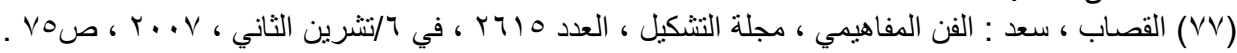

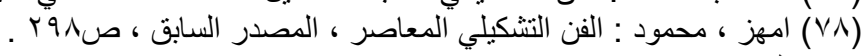

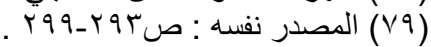

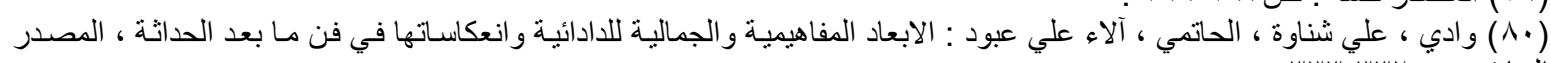

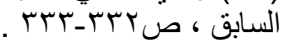

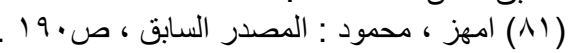

(r) http://www.visual-arts-cork.com/contempororg-art-movements (

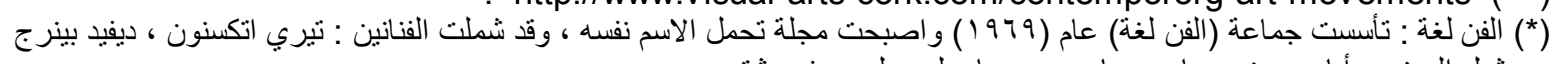

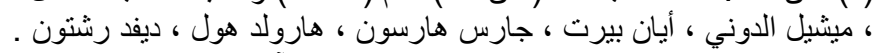

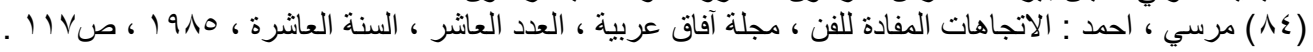

(2) The Avant - Gard in the late 20th century, lbid 45 .

(3) http;//www.ameinto.com/ar .

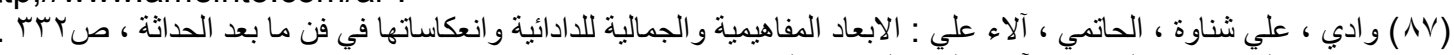
(^^)

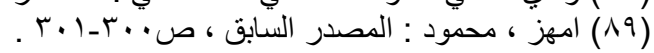

( 7 ) Hudeion, Mark : Movements in Twentieth - Century Art After world war II , Ibid

(1) www.artlex.com (1996-2004) michal Delahunt .

(2) Elizabeth Armstrong and Joan Roth finss, In the spirit of fluxus (minneap oils : walker Art center, 1993 ), P.652.

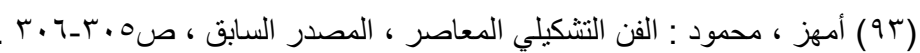

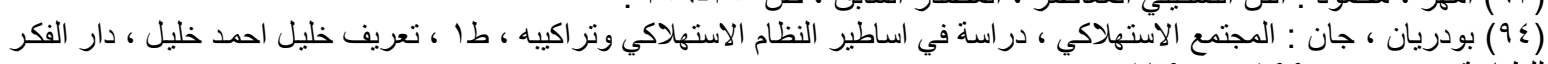

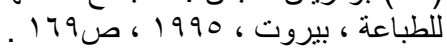

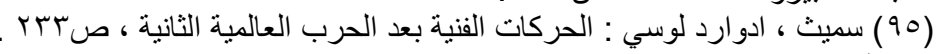
(1) (1) ملحق (")

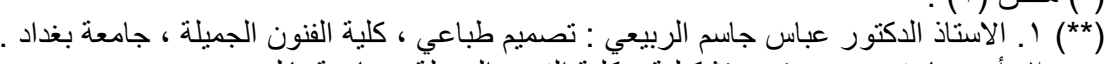

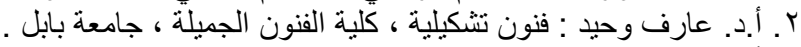

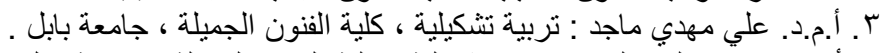

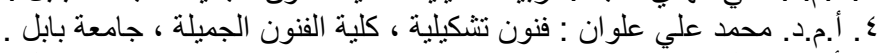
ه. أ.م.د. دلال حمزة محمد : نربية تشكيلية ، كلية الفنون الجميلة ، جامعة بابلة ، جابل . 
(***) أ.م.د. دلال حمزة محمد : نربية فنبة ، كلبة الفنون الجميلة ، جامعة بابل .

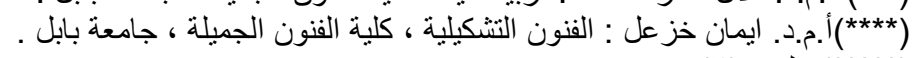

(1) Fietzek, Gerti , Writing and interviews of Lawrance Weiner 1963-2003, ostfildem - ruit :

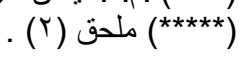
hatjecatz , 2004, P.55

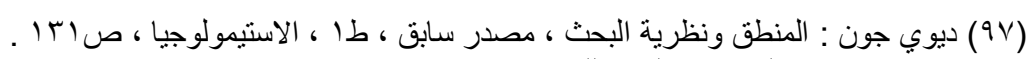

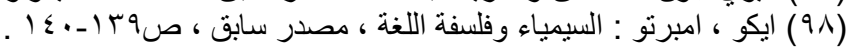

(2) The A Vant - Gard in the late 20 th century, P.45

(1) Fie-Tzek, Gerti ; writing and inter riews of Lawrance Weiner, Ibid, P.55 . 